\title{
ASSESSMENT OF EFFECTS OF MILITARY MANEUVERS ON THE STREAMFLOW, WATER QUALITY, AND SEDIMENT YIELDS AT THE U.S. ARMY PINON CANYON MANEUVER SITE, LAS ANIMAS COUNTY, COLORADO by Paul von Guerard, R.S. Parker, and R.G. Dash
}

U.S. GEOLOGICAL SURVEY

Water-Resources Investigations Report 91-4095

Prepared in cooperation with the

U.S. DEPARTMENT OF THE ARMY,

FORT CARSON MILITARY RESERVATION 


\section{U.S. DEPARTMENT OF THE INTERIOR MANUEL LUJAN, JR., Secretary}

U.S. GEOLOGICAL SURVEY

Dallas L. Peck, Director

For additional information write to:

District Chief U.S. Geological Survey Box 25046, Mail Stop 415 Federal Center Denver, CO 80225-0046
Copies of this report can be purchased from:

U.S. Geological Survey Books and Open-File Reports Section Federal Center Box 25425

Denver, CO 80225-0425 
Page

Abstract-

Introduction--

Purpose and scope-10 4

Description of study area- 5

Acknowledgments- 8

Precipitation- 8

Temporal and spatial distribution of precipitation at the Maneuver Site-- 8

Change in precipitation at the Maneuver Site between pre- and postmaneuver periods-14

Effects of precipitation on vegetation- 18

Effects of military maneuvers on streamflow- 19

Contribution of tributary streamflow to the Purgatoire River---.-- 19

Streamflow in the Purgatoire River- 21

Change in streamflow for Chacuaco Creek at mouth, near Timpas,

between the pre- and postmaneuver periods- 24

Streamflow at the Maneuver Site-10 24

Effects of conservation practices on flood frequency at the Maneuver Site-1.- 28

Effects of military maneuvers on surface-water quality-_. 29

Instream water-quality standards for the Purgatoire River-_- 29

Summary statistics and analysis of change between pre- and postmaneuver periods for selected water-quality properties and constituents-1.- 40

Specific conductance in the Purgatoire River-a 43

Specific conductance for streamflow in streams that drain the Maneuver Site-1. 46

Limitations of data analysis- 47

Dissolved-solids and suspended-sediment loads-_- 47

Dissolved-solids loads-- 47

Suspended-sediment loads-- 49

Effects of military maneuvers on sediment yields- 50

Sediment-yield estimates on the Maneuver Site-n

Sediment-yield estimates from areas unaffected by military maneuvers 56

Drainage-basin modeling- 56

Precipitation-Runoff Modeling System (PRMS)-_. 57

Taylor Arroyo drainage basin- 61

Data collection and drainage-basin segmentation-_. 62

Calibration of Precipitation-Runoff Modeling System in the daily mode-- 62

Calibration of Precipitation-Runoff Modeling System in the unit mode 66

Changes in the storm hydrograph with increased military maneuvers--- 77

Summary-1 80

References cited-1 83

PLATE

Plate 1. Map showing location of surface-water, precipitation, and sediment-yield data collection network at the U.S. Army Pinon Canyon Maneuver Site, Las Animas County, Colorado- In pocket 
Figure 1. Map showing location of the Pinon Canyon Maneuver Site-----

Page

2. Map showing locations of precipitation gages in Taylor

Arroyo drainage basin-

3. Monthly mean precipitation at the Pinon Canyon Maneuver Site from August 1983 through September 1987 compared to 40-year (1947-87) mean monthly precipitation at the Las Animas

County Airport-

4. Map showing precipitation for August 3, 1987, in the Taylor

Arroyo drainage basin--

5. Example of a box plot-

6-12. Graphs showing:

6. Monthly mean precipitation at the Pinon Canyon Maneuver Site for pre- and postmaneuver periods-..-

7. Lowess curve of smoothed annual streamflow at the streamflow-gaging station Purgatoire River near Thatcher (site S4) for water years 1968 through $1987-0$

8. Estimates of irrigation-return flow at the streamflowgaging station Van Bremer Arroyo near Model (Site S3) for water years 1984 through 1987-

9. Selected chemical properties and constituents and instream water-quality standards for the streamflow-gaging station Purgatoire River near Thatcher (Site S4) for water years 1983 through 1987--..-

10. Selected chemical properties and constituents and instream water-quality standards for the streamflow-gaging station Purgatoire River at Rock Crossing, near Timpas (Site S10), for water years

11. Flow-adjusted concentrations of total-recoverable iron for the Purgatoire River at Rock crossing, near Timpas (site S10) for water years 1983 through 1987--

12. Estimated mean annual sediment yields for small drainage basins in and near the Pinon Canyon Maneuver Site for 1983 through 1985 and 1987-....-

13. Diagram showing a conceptual drainage-basin system and inputs to modeling system-

14. Map showing locations of hydrologic response units in the

Taylor Arroyo drainage basin
15. Graphs showing daily mean precipitation and simulated soil moisture for the Taylor Arroyo drainage basin for water year 1987-

16. Graphs showing daily mean precipitation and measured and simulated streamflow for the Taylor Arroyo drainage basin for water year 1987

17. Diagram showing channel segmentation for hydrologic response units in the Taylor Arroyo drainage basin-

18. Graphs showing hyetographs for basin mean precipitation and for individual hydrologic response units (HRU) in the Taylor Arroyo drainage basin for August 9-10, 1987--..-- 
Figure 19. Map showing precipitation for August 9-10, 1987, in the

Taylor Arroyo drainage basin-_... 74

20. Graph showing measured and simulated streamflow for August 9-10, 1987, in the Taylor Arroyo drainage basin-----

21. Graph showing simulated streamflow hydrograph for existing land-use conditions and hypothetical increased military training for August 9-10, 1987, in the Taylor Arroyo

drainage basin-...

\section{TABLES}

Table 1. Periods of military training and training areas used, July 1985 through November 1987- 4

2. Summary of information for selected streamflow-gaging, water-quality, and suspended-sediment stations located in and near the Pinon Canyon Maneuver Site-cos

3. Summary of precipitation at the Pinon Canyon Maneuver Site from August 1983 through September $1987-1$ the Pinon Canyon Maneuver Site from August 1983 through

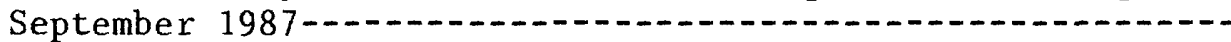
-values for the Spearman correlation coefficient (rho) for monthly mean precipitation, monthly streamflow, and monthly mean specific-conductance data for selected sites in and near the Pinon Canyon Maneuver Site-..-

6. Streamflow at streamflow-gaging stations in and near the Pinon Canyon Maneuver Site for water years 1984 through 1987-...

7. Summary statistics for monthly streamflow at streamflowgaging stations in and near the Pinon Canyon Maneuver Site for pre- and postmaneuver periods-.

8. Overall and seasonal p-values from seasonal rank-sum test of monthly streamflow between pre- and postmaneuver periods at streamflow-gaging stations Van Bremer Arroyo near Model (site S3) and Lockwood Canyon Creek near Thatcher (site S6)

9. Number of streamflow events at ephemeral streamflow-gaging stations at the Pinon Canyon Maneuver Site for water years 1984 through 1987

lected drainage-basin characteristics, estimates of flood magnitude for selected recurrence intervals, percent difference from premaneuver land-use estimates of flood magnitude, and recorded peak discharge for period of record for streamflow-gaging stations along streams draining the Pinon Canyon Maneuver Site-..

11. Summary statistics for selected water-quality properties and constituents-

12. Overall p-values from seasonal rank-sum test for change between pre- and postmaneuver periods for a selected water-quality property or constituent- 
Table 13. Summary statistics of monthly mean specific conductance for pre- and postmaneuver periods for selected streamflowgaging stations in and near the Pinon Canyon Maneuver Site-

14. Dissolved-solids load at streamflow-gaging stations in and near Pinon Canyon Maneuver Site for water years 1984 through 1987-

15. Suspended-sediment load at streamflow-gaging stations in and near Pinon Canyon Maneuver Site for water years 1984 through 1987-...

16. Factors for estimating mean annual sediment yield--.-.--

17. Rating conversions used for estimating sediment yield-------

18. Values used for estimating mean annual sediment yield using the Pacific Southwest Inter-Agency Committee method in small drainage basins in and near the Pinon Canyon Maneuver

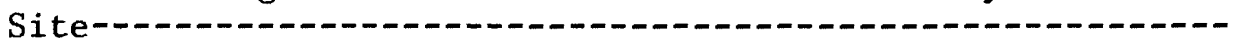

19. Selected model parameters and definitions-_-

20. Summary of information for hydrologic response units for the Taylor Arroyo drainage basin--.-

21. Selected parameter values used in Precipitation-Runoff Modeling System simulations for the Taylor Arroyo drainage basin for water year 1987--

22. Water balance from Precipitation-Runoff Modeling System simulations for the Taylor Arroyo drainage basin for water year 1987--_-

23. Characteristics of channel segments defined for unit mode of
the Precipitation-Runoff Modeling System for the Taylor
Arroyo drainage basin-

23. Characteristics of channel segments defined for unit mode
the Precipitation-Runoff Modeling System for the Taylor
Arroyo drainage basin-

23. Characteristics of channel segments defined for unit mode of
the Precipitation-Runoff Modeling System for the Taylor
Arroyo drainage basin-values for disturbed and undisturbed areas of each hydrologic response unit in the Taylor Arroyo drainage basin----

CONVERSION FACTORS AND RELATED INFORMATION

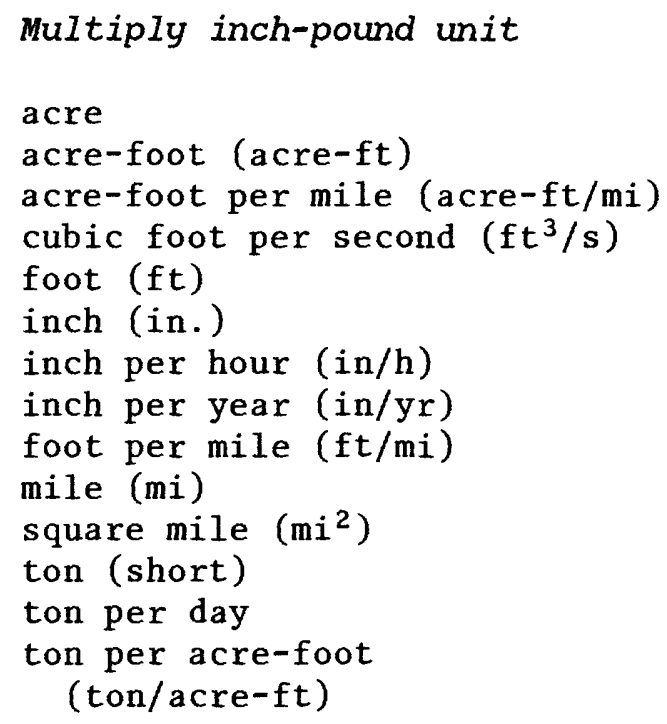

$B y$
0.4047
0.001233
0.00123
0.028317
0.3048
25.4
25.4
25.4
0.1894
1.609
2.590
0.9072
0.9072
735.77

To obtain metric unit

hectares

cubic hectometer

cubic hectometer per mile cubic meter per second meter millimeter millimeter per hour millimeter per year meter per kilometer kilometer square kilometer megagram megagram per day megagram per cubic hectometer 
Degree Celsius $\left({ }^{\circ} \mathrm{C}\right)$ may be converted to degree Fahrenheit $\left({ }^{\circ} \mathrm{F}\right)$ by using the following equation:

$$
{ }^{\circ} \mathrm{F}=9 / 5\left({ }^{\circ} \mathrm{C}\right)+32 \text {. }
$$

Degree Fahrenheit $\left({ }^{\circ} \mathrm{F}\right)$ may be converted to degree Celsius $\left({ }^{\circ} \mathrm{C}\right)$ by using the following equation:

$$
{ }^{\circ} \mathrm{C}=\left({ }^{\circ} \mathrm{F}-32\right) \times 5 / 9 .
$$

The following terms and abbreviations also are used in this report:

$$
\text { gram per cubic centimeter }\left(\mathrm{g} / \mathrm{cm}^{3}\right)
$$$$
\text { milligram per liter }(\mathrm{mg} / \mathrm{L})
$$$$
\text { microgram per liter }(\mu \mathrm{g} / \mathrm{L})
$$

microsiemens per centimeter at 25 degrees Celsius $(\mu \mathrm{S} / \mathrm{cm})$

Suspended-sediment concentrations are given only in milligrams per liter because these values are (within the range of values presented) numerically equal to concentrations expressed in parts per million. 


\title{
ASSESSMENT OF EFFECTS OF MILITARY MANEUVERS ON THE STREAMFLOW, WATER QUALITY, AND SEDIMENT YIELDS AT THE U.S. ARMY PINON CANYON MANEUVER SITE, LAS ANIMAS COUNTY, COLORADO \\ By Paul von Guerard, R.S. Parker, and R.G. Dash
}

\begin{abstract}
The U.S. Department of the Army began military maneuvers at the 381square-mile Pinon Canyon Maneuver Site in July 1985. The effects of military maneuvers on the surface water of the Maneuver Site and on the Purgatoire River are of concern to the military and to downstream water users. Streamflow, water-quality, and sediment-yield data are analyzed graphically and statistically to determine changes between pre- and postmaneuver periods.

Temporal and spatial distribution of precipitation from August 1983 through September 1987 at the Maneuver Site is summarized. Mean monthly precipitation at the Maneuver Site for this period is compared to 40-year mean monthly precipitation for the Las Animas County Airport. Monthly precipitation at the Bent Canyon gage for May 1987 was 6.17 inches and was exceeded once at the airport during the period of record (1947-87). There was no trend in monthly precipitation during $1983-87$ at the Maneuver Site.
\end{abstract}

With the exception of Van Bremer Arroyo near Model, there was no significant difference in streamflow existed between pre- and postmaneuver periods for streams in and near the Maneuver Site. During the base streamflow period (November through March) and the summer streamflow period (July through October), a statistically significant increase in streamflow occurred at Van Bremer Arroyo near Model. The increase may be a result of irrigation return flows from farmland adjacent to the Maneuver Site.

Changes in water quality, particularly increases in dissolved solids that could affect downstream agricultural water users, were investigated. Dissolved oxygen, flow-adjusted concentrations of selected water-quality constituents, and flow-adjusted monthly mean specific conductance at the streamflow-gaging stations Purgatoire River near Thatcher and Purgatoire River at Rock Crossing, near Timpas, were tested for changes between the pre- and postmaneuver periods. Except for total-recoverable zinc at the Purgatoire River near Thatcher, there was no significant difference ( $p>0.05)$ in dissolved oxygen, selected water-quality constituents, or monthly mean specific conductance between the pre- and postmaneuver periods.

Monthly mean specific conductance for all streamflow-gaging stations at the Maneuver Site and Chacuaco Creek at mouth, near Timpas was analyzed for change between pre- and postmaneuver periods. No significant difference ( $p>0.05)$ in monthly mean specific conductance was detected at these streamflow-gaging stations. 
The effects of military maneuvers on sediment yields were evaluated by using a qualitative method for estimating mean annual sediment yields that was developed by the Pacific Southwest Inter-Agency Committee. Sediment yields were estimated for 1983-84 for 28 drainage basins in and near the Maneuver Site prior to the start of military maneuvers. Twenty-one of these drainage basins are located on the Maneuver Site and seven are located outside the Maneuver Site on adjacent rangeland. Drainage areas of these drainage basins ranged in size from 0.10 to 1.2 square miles.

Generally, estimated sediment yields tended to decrease for the drainage basins on the Maneuver Site. During water years 1983 through 1987, improvement in ground cover and changes in the intensity and patterns of land use tended to offset and lessen the effects of military maneuvers on sediment yields. During November 1987, sediment yields were estimated for seven drainage basins located off the Maneuver Site. Estimated sediment yields for the postmaneuver period indicated a decrease for six drainage basins and no change for one.

The Precipitation-Runoff Modeling System was used to simulate changes in streamflow from the August 9, 1987, storm by using hypothetical effects from military maneuvers. The hypothetical scenario increased the simulated peak streamflow about 1.2 percent; there was no change in the timing of the streamflow.

\section{INTRODUCTION}

The U.S. Department of the Army acquired $381 \mathrm{mi}^{2}$ of semiarid rangeland in southeastern Colorado for mechanized military maneuvers. The area, known as the Pinon Canyon Maneuver Site (fig. 1), hereinafter referred to as the Maneuver Site, is located on the northwestern side of the Purgatoire River between the towns of Trinidad and La Junta.

During the last 100 years, the area has been used primarily for livestock grazing. After the acquisition of the Maneuver Site by the U.S. Army in 1983, livestock grazing was discontinued. Military maneuvers, which are done on a periodic basis at the Maneuver Site, began July 29, 1985. Six training rotations occurred through November 1987 (table 1). A typical training rotation lasts 4 weeks and has about 2 weeks of actual onsite maneuvers. A training rotation involves about 3,200 personnel and 1,160 vehicles, of which about 450 are tracked vehicles, including the M-60 tank and the M-113 armored personnel carrier. Other training occurs periodically, usually involving fewer than 500 personnel, fewer than 150 wheeled vehicles, and no tracked vehicles.

The Maneuver Site is divided into five training areas (pl. 1; fig. 1). Military maneuvers were rotated among the five training areas during July 1985 through November 1987 (table 1). The rotation of military maneuvers between training areas provides for a period of nonuse for each area. During the period of nonuse, any damage to vegetation and soils that results from military maneuvers may be mitigated by natural processes or artificial methods. 

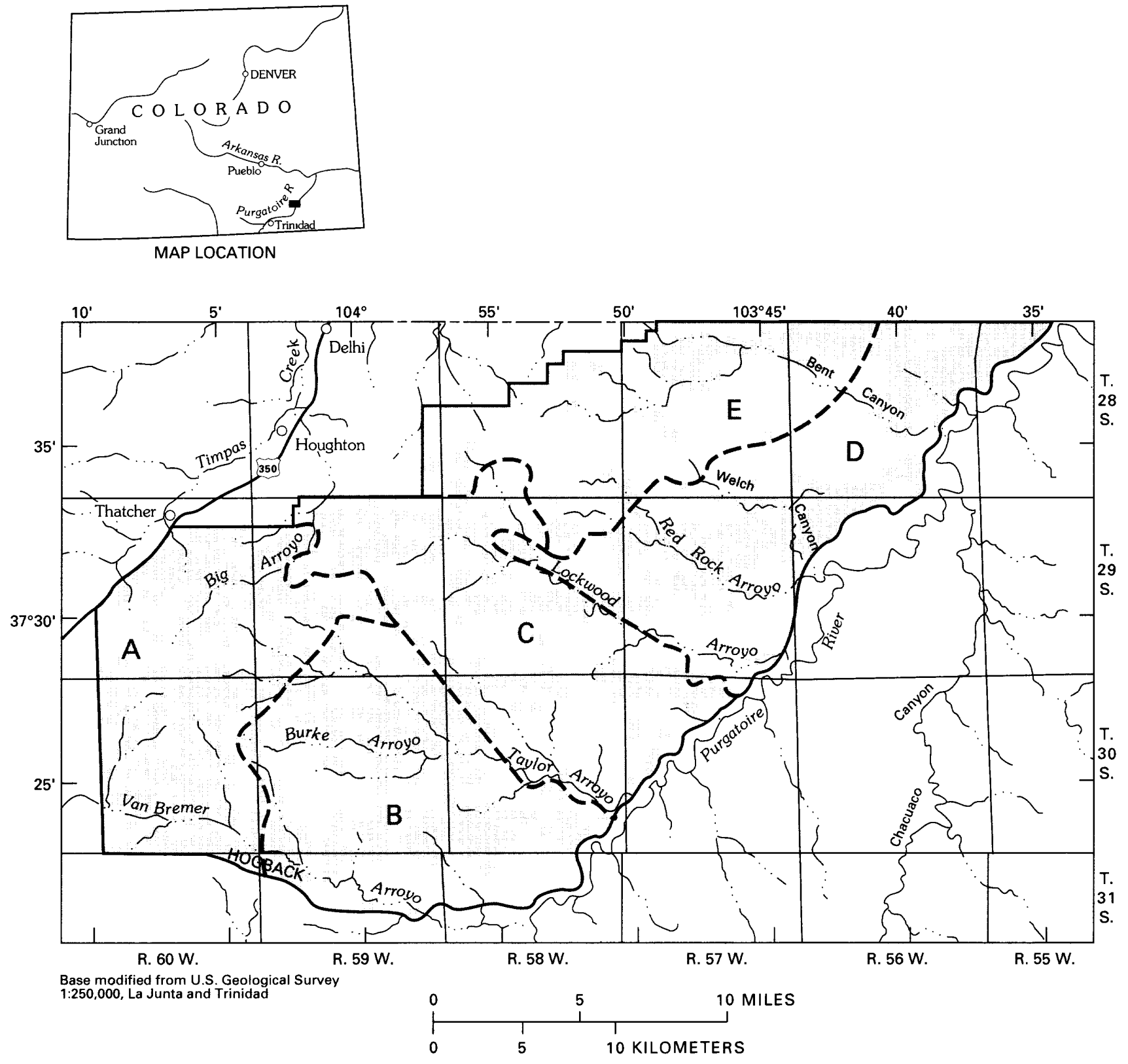

EXPLANATION

A TRAINING AREA

- - TRAINING AREA BOUNDARY

PINON CANYON

MANEUVER SITE

Figure 1.--Location of the Pinon Canyon Maneuver Site. 
Table 1.--Periods of military training and training areas used, July 1985 through November 1987

Period of military training

Training areas used (letter designation on pl. 1; fig. 1)

07-29-85 through 08-28-85

02-24-86 through 03-15-86

07-09-86 through 08-13-86

10-13-86 through 11-16-86

03-02-87 through $03-30-87$

10-19-87 through 11-22-87
$\mathrm{A}, \mathrm{B}, \mathrm{C}$

$\mathrm{A}, \mathrm{B}, \mathrm{C}$

$A, B, C$

$A, B, C$

$B, C, D$

$\mathrm{C}, \mathrm{D}, \mathrm{E}$

Because the change in land use could alter streamflow, water quality, and sediment yields, and because the magnitude of these changes could not be predicted, an environmental impact statement for the land acquisition was prepared. However, the changes are of concern to the military and to downstream water users in Colorado and Kansas. The House of Representatives Armed Services Committee, in Report No. 97-44, Military Construction Authorization Act, Fiscal Year 1982, page 7, recognized that commitments made by the U.S. Department of the Army in the environmental impact statement should be met and, thus, directed the U.S. Department of the Army to take the necessary steps to ensure the fulfillment of those commitments, including:

"...ensuring the establishment of a system of water-quality monitoring, in cooperation with the U.S. Geological Survey to collect baseline data upon acquistion of the training area to record the effects of varying degrees of use of land on the quality of water on the land and flowing from the land acquired..."

In 1983, the U.S. Geological Survey, in cooperation with the U.S. Department of the Army, Fort Carson Military Reservation began a study to assess the water resources and related effects resulting from military training at the Maneuver Site.

\section{Purpose and Scope}

This report describes the effects of military maneuvers on the quantity and quality of surface-water resources and sediment yields at the Pinon Canyon Maneuver Site and the Purgatoire River in the vicinity of the Maneuver Site. Data collection on the Maneuver Site began during water year 1983 and continued through water year 1987. Data collected and described for the baseline assessment of hydrologic conditions at the Maneuver Site (von Guerard and others, 1987) provide the premaneuver period of reference for assessing the effects of military maneuvers on the surface water of the area. Specifically, the period of data analyzed was divided into a premaneuver period (through July 31, 1985) and a postmaneuver period (after July 31, 1985). Except for sediment-yield estimates made in November 1987, only data collected through 
September 1987 are discussed in this report. Annual precipitation data collected from a network of four precipitation gages located throughout the Maneuver Site (pl. 1) are summarized in this report. Continuous measurements of streamflow, specific conductance, and water temperature, and periodic collection of water-quality samples are summarized for a network of 11 streamflow-gaging stations (table 2; pl. 1). Data from streamflow-gaging stations Van Bremer Arroyo near Thatcher (site S2) and Van Bremer Arroyo near Tyrone (site S2A) (von Guerard and others, 1987) were not analyzed in this report because of the short period of record available for each streamflow gage. Daily records of suspended-sediment data collected at six of the streamflowgaging stations are presented (table 2; pl. 1). Streamflow-gaging stations were assigned site numbers that correspond to those used by von Guerard and others (1987).

Mean annual sediment yields for 29 of the drainage basins above the stock-watering reservoirs were estimated for the premaneuver period using the method developed by the Pacific Southwest Inter-Agency Committee (1968) (PSIAC) (von Guerard and others, 1987). During the postmaneuver period, sediment yields were reestimated for 28 of the 29 small drainage basins in order to assess any changes in sediment yields between pre- and postmaneuver periods. Small drainage basins upstream from these drainage basins range in size from 0.10 to $1.2 \mathrm{mi}^{2}$. Analysis of sediment yields is done for the preand postmaneuver periods for 21 of the stock-watering reservoirs on the Maneuver Site and for 7 drainage basins offsite (p1. 1).

Precipitation and streamflow data collected in the Taylor Arroyo drainage basin (fig. 2) during water year 1987 were used to calibrate the Precipitation-Runoff Modeling System (PRMS). A method using PRMS to examine the effects of military maneuvers on storm runoff in the Taylor Arroyo drainage basin is described.

Effects of military land use on ground-water resources are not expected to be substantial and, thus, were not examined. Ground-water resources at the Maneuver Site are described in von Guerard and others (1987).

\section{Description of Study Area}

The Maneuver Site is $381 \mathrm{mi}^{2}$ in area and is entirely within the Arkansas River drainage basin. About 96 percent of the Maneuver Site drains eastward to the Purgatoire River; the remaining 4 percent drains north and east into Timpas Creek. The streams that drain the Maneuver Site are intermittent or ephemeral (table 2) and occupy shallow valleys that cross the rolling plains of the study area. Near the confluence with the Purgatoire River, the tributary stream channels become entrenched in the sandstone of the canyon rim and form side canyons to the main canyon. Near the upper ends of the side canyons, the channels of some of the tributary streams intersect the water table, and the streams become perennial or intermittent downstream from that point. Elevation of the Maneuver Site ranges from 5,905 ft at the highest point near Big Arroyo Hills to about 4,350 ft where the Purgatoire River flows out of the study area. 
Table 2.--Summary of information for selected streamflow-gaging, water-quality, and suspended-sediment stations located in and near the Pinon Canyon Naneuver site

[e, ephemeral; i, intermittent; $p$, perennial]

\begin{tabular}{|c|c|c|c|c|c|c|}
\hline $\begin{array}{l}\text { Site } \\
\text { number } \\
\text { on } \\
\text { plate } 1\end{array}$ & $\begin{array}{l}\text { U.S. Geolog- } \\
\text { ical Survey } \\
\text { station } \\
\text { number }\end{array}$ & $\begin{array}{l}\text { U.S. Geological Survey } \\
\text { station name }\end{array}$ & $\begin{array}{l}\text { Total drain- } \\
\text { age area } \\
\text { (square } \\
\text { miles) }\end{array}$ & $\begin{array}{l}\text { Period of } \\
\text { record }\end{array}$ & $\begin{array}{l}\text { Stream } \\
\text { type }\end{array}$ & $\begin{array}{l}\text { Daily } \\
\text { suspended } \\
\text { sediment } \\
\text { collected }\end{array}$ \\
\hline S1 & 07120620 & Big Arroyo near Thatcher............. & 15.5 & March 1983- & e & Yes \\
\hline$S 2^{1}$ & 07126130 & Van Bremer Arroyo near Thatcher- & 80.6 & $\begin{array}{l}\text { March 1983- } \\
\text { May } 1985\end{array}$ & e & No \\
\hline S3 & 07126200 & Van Bremer Arroyo near Model-... & 175 & July 1966- & i & No \\
\hline 54 & 07126300 & Purgatoire River near Thatcher-- & ${ }^{2} 1,791$ & $\begin{array}{l}{ }^{3} \text { July } 1966 \text { to } 1976 \text {; } \\
\text { 1977- }\end{array}$ & $\mathbf{p}$ & Yes \\
\hline 57 & 07126415 & $\begin{array}{l}\text { Red Rock Canyon Creek at mouth, } \\
\text { near Thatcher. }\end{array}$ & 48.8 & May 1983- & e & No \\
\hline 58 & 07126470 & $\begin{array}{l}\text { Chacuaco Creek at mouth, near } \\
\text { Timpas. }\end{array}$ & 424 & May 1983- & e & Yes \\
\hline S9 & 07126480 & $\begin{array}{l}\text { Bent Canyon Creek at mouth, } \\
\text { near Timpas. }\end{array}$ & 56.2 & May 1983- & e & Yes \\
\hline S10 & 07126485 & $\begin{array}{l}\text { Purgatoire River at Rock } \\
\text { Crossing, near Timpas. }\end{array}$ & 2,635 & June 1983- & $\mathbf{p}$ & Yes \\
\hline
\end{tabular}

${ }^{1}$ Data from streamflow-gaging stations Van Bremer Arroyo near Thatcher (site S2) and Van Bremer Arroyo near Tyrone (site S2A) (von Guerard and others, 1987) were not analyzed in this report because of the short period of record available for each streamflow gage.

${ }^{2}$ Revised, previously reported as 1,935 square miles.

${ }^{3}$ Construction of Trinidad Reservoir completed August 1977.

The geologic units at the Maneuver Site mainly consist of sedimentary rocks including limestone, shale, and sandstone; basaltic dikes occur along the southern boundary. The primary sedimentary formations exposed at the land surface all are of Cretaceous age, and in descending order these are the Niobrara Formation, Carlile Shale, Greenhorn Limestone, Graneros Shale, Dakota Sandstone, and Purgatoire Formation. Other formations that crop out are of limited extent and are associated with the canyon areas along the eastern border of the Maneuver Site. For further information about the geology of the study area, see von Guerard and others (1987, p. 9-13). 


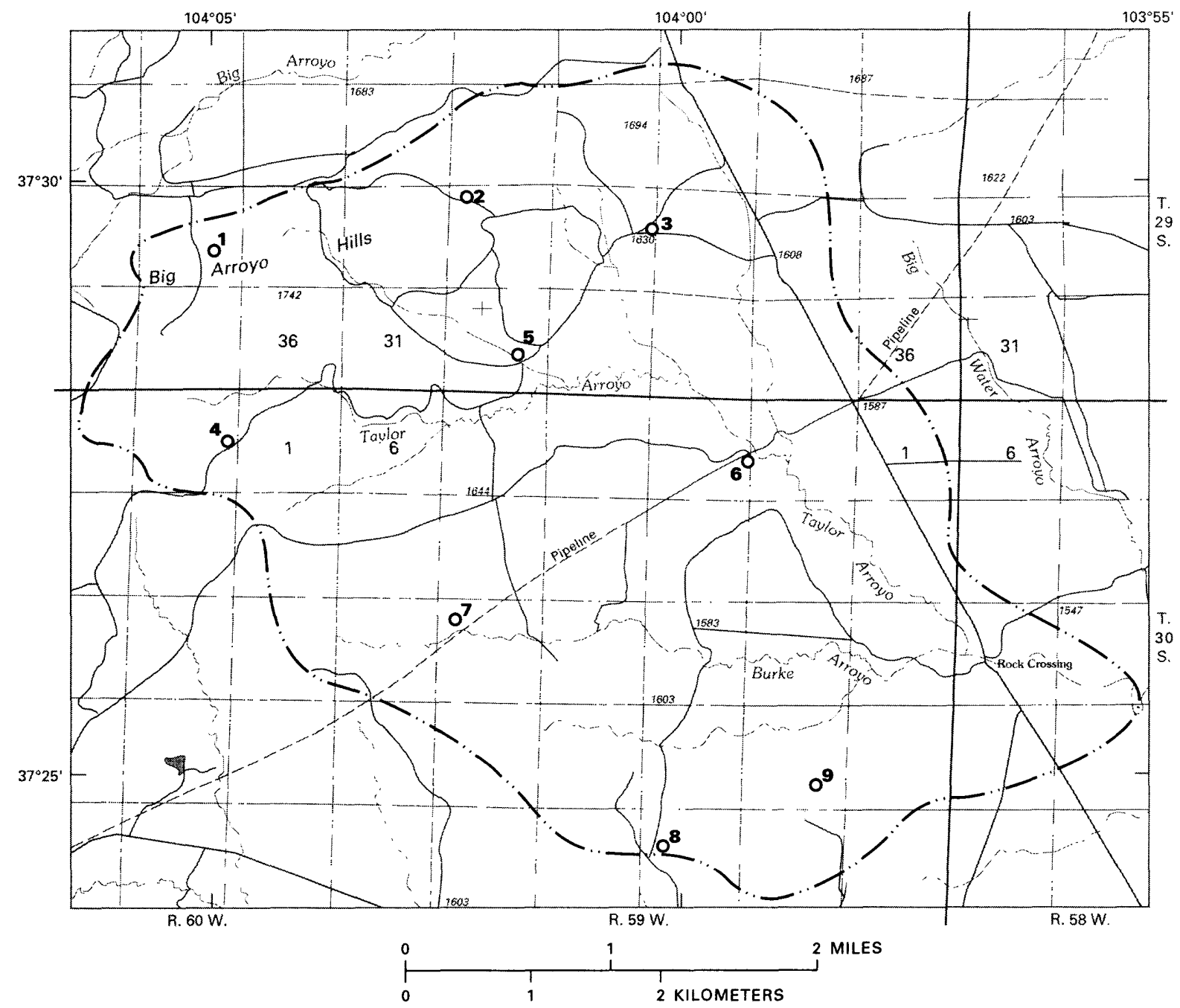

EXPLANATION

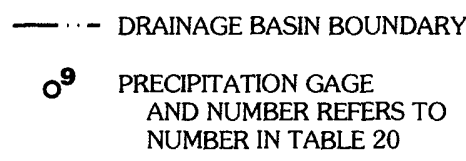

Figure 2.--Locations of precipitation gages in Taylor Arroyo drainage basin. (See plate 1 for location of basin.)

Near-surface geology and climate determine the type of soils that develop in the area. Soils developed in areas underlain by shale and limestone are silty and have a fine texture; soils underlain by sandstone tend to be sandy and loamy. Soils are slightly to moderately salt- and alkali-affected, except for soils associated with the igneous basaltic units. All soils generally are well drained and have depths that range from 5 to $60 \mathrm{in.}$ (U.S. Soil Conservation Service, 1983). 
The climate at the Maneuver Site is semiarid. Warm daytime temperatures and low relative humidity cause large evaporation rates at the Maneuver Site. Long-term temperature records are available for the Las Animas County Airport, located about $5 \mathrm{mi}$ northeast of Trinidad. Records for 1972 to 1987 indicate a mean annual temperature of $52.5^{\circ} \mathrm{F}$; the maximum mean monthly temperature was $89.1^{\circ} \mathrm{F}$ during July; the minimum mean monthly temperature was $23.3^{\circ} \mathrm{F}$ during January (National Climatic Data Center, 1972-87). From 1972 through 1987, evaporation rates were measured during April through October at Springfield, Colo., $70 \mathrm{mi}$ east of the Maneuver Site, and averaged 69.1 in. (National Climatic Data Center, 1972-87). Mean annual precipitation at the Maneuver Site for 1951-80 was about 12 in. (Colorado Climate Center, 1984). Precipitation measured at the precipitation network during water years 1984 through 1987 averaged 12.39 in/yr.

\section{Acknowledgments}

The authors thank Robert S. Shaw of the Department of Range Science at Colorado State University for his review of this report. The authors also thank Mr. Shaw for providing insight into the complexities of the vegetal communities at the Maneuver Site.

\section{PRECIPITATION}

The temporal and spatial distribution of precipitation in the semiarid environment causes problems for the land manager. To effectively rehabilitate land that was damaged by military maneuvers, the characteristic variability of precipitation at the Maneuver Site needs to be understood. Monthly precipitation data are available for four sites within the Maneuver Site from August 1983 through September 1987 (p1. 1; table 3), and seasonal precipitation data for water year 1987 are available for analysis for July through September for the nine sites in the Taylor Arroyo drainage basin (fig. 2). Summary statistics of precipitation data for the four sites within the Maneuver Site are presented in table 4. The following sections are a discussion of the temporal and spatial characteristics, the change in precipitation between pre- and postmaneuver periods, and the effects of precipitation on vegetation at the Maneuver Site.

\section{Temporal and Spatial Distribution of Precipitation at the Maneuver Site}

The timing, spatial distribution, and quantities of precipitation at the Maneuver Site affect the processes of surface runoff and soil erosion and may determine the effectiveness of certain conservation practices implemented to mitigate the effects of military maneuvers. Precipitation at the Maneuver Site primarily results from either frontal storms or convective storms. Frontal storms can occur throughout the year and have varying strength and frequency; the largest quantities of precipitation are associated with periods of moist airflow from the Gulf of Mexico. Convective storms occur frequently during July through September. Areal distribution of precipitation associated with frontal storms is more uniform than with convective storms, which tend to have large variations in spatial distributions of precipitation. 
Table 3.--Summary of precipitation at the Pinon Canyon Maneuver Site from August 1983 through September 1987

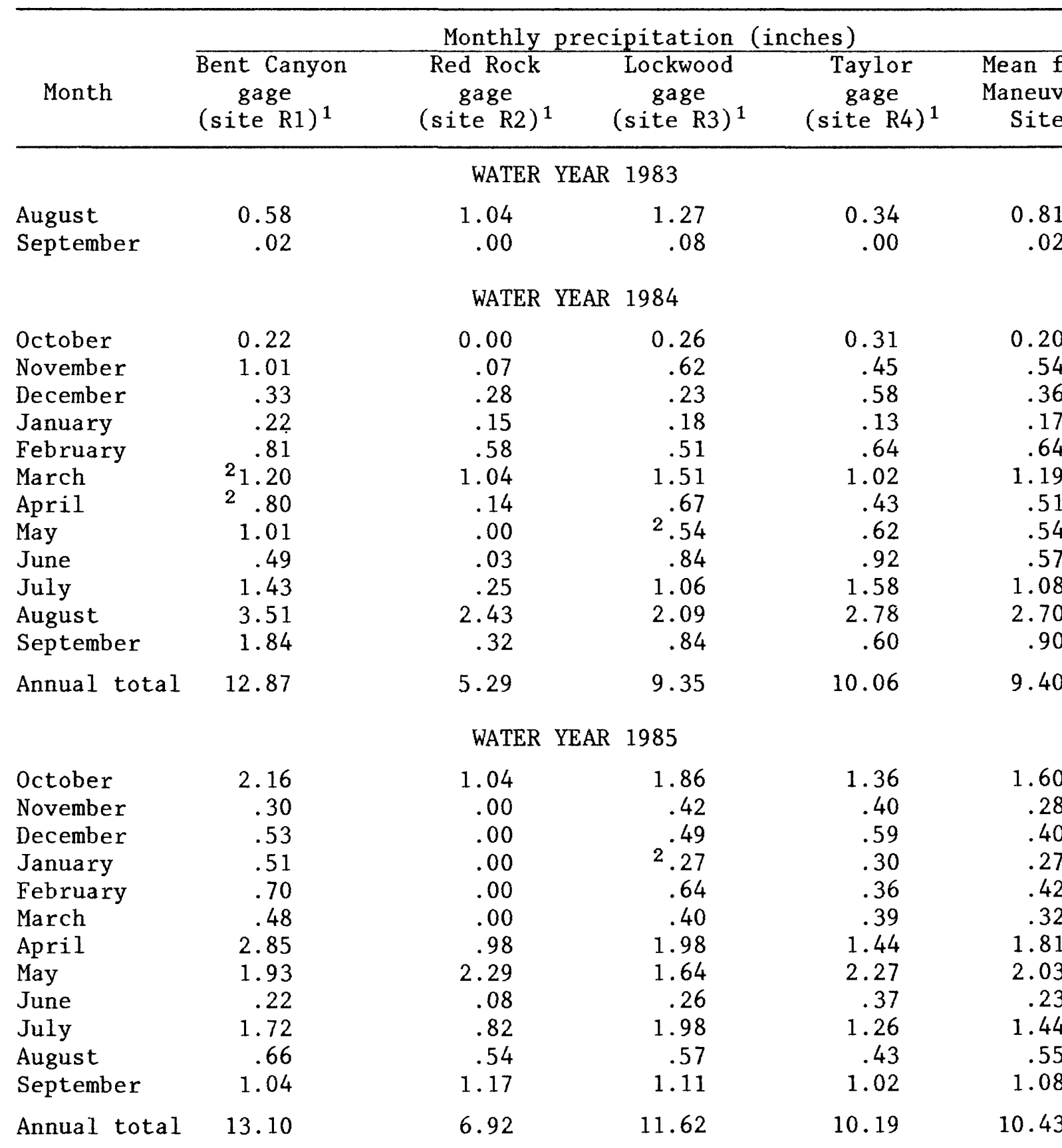


Table 3.--Summary of precipitation at the Pinon Canyon Maneuver Site from August 1983 through September 1987--Continued

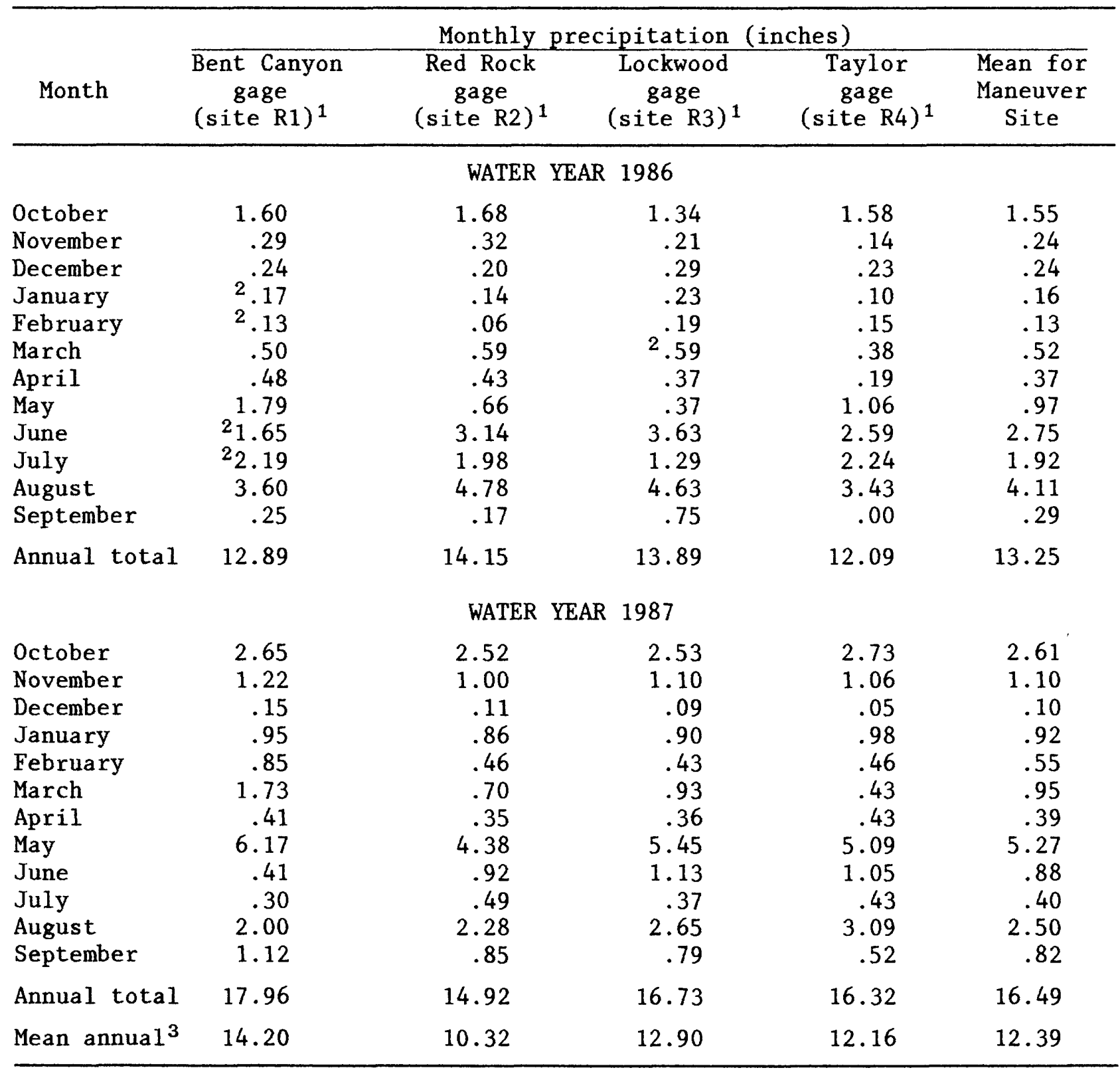

${ }^{1}$ Site number on plate 1.

${ }^{2}$ Daily precipitation data are incomplete. Missing days estimated based on precipitation at nearby sites, streamflow, and reservoir inflow records.

${ }^{3}$ For water years 1984 through 1987. 
Table 4.--Selected summary statistics for monthly precipitation at the Pinon Canyon Maneuver Site from August 1983 through September 1987

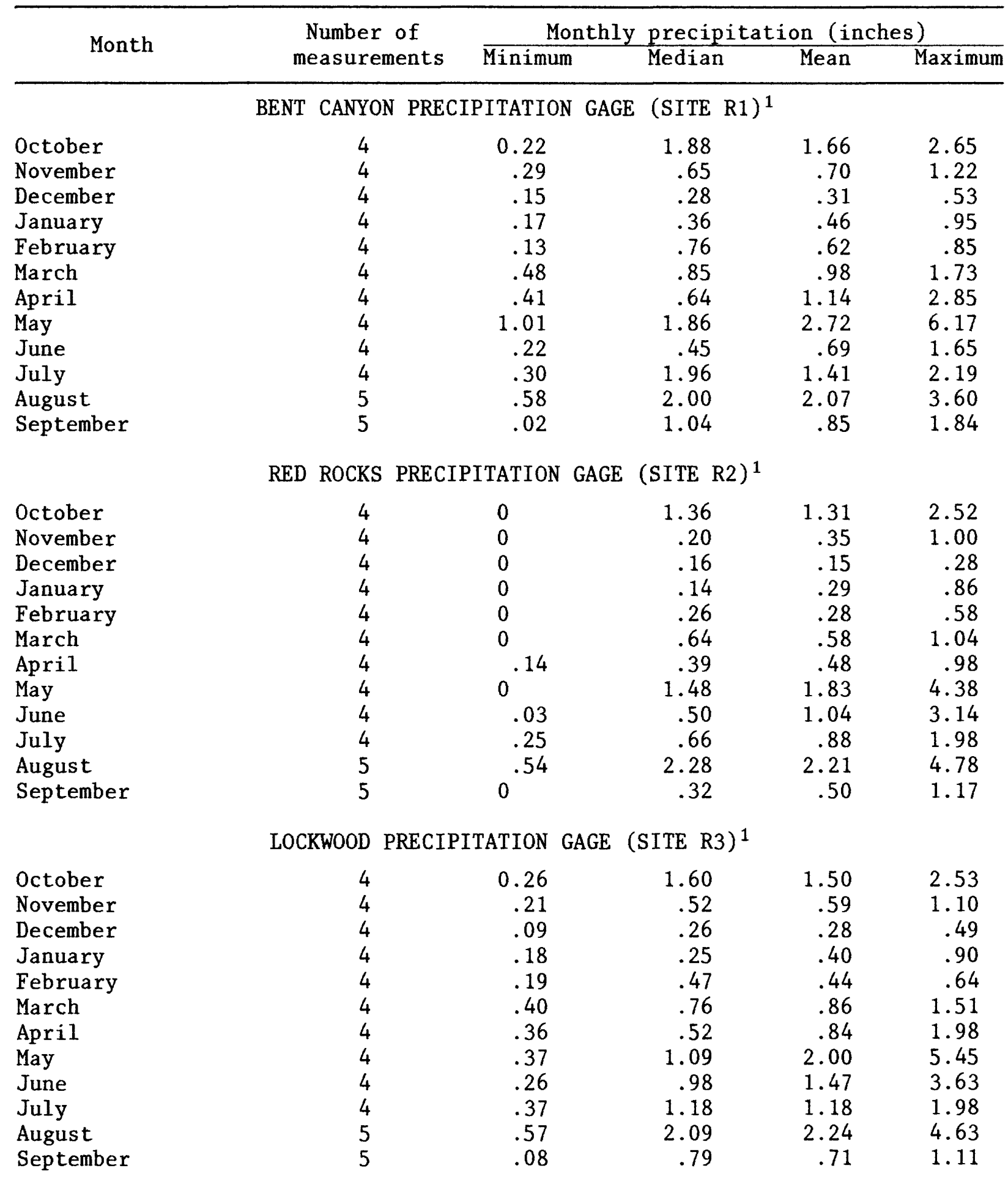


Table 4.--Selected summary statistics for monthly precipitation at the Pinon Canyon Maneuver Site from August 1983 through September 1987--Continued

\begin{tabular}{|c|c|c|c|c|c|}
\hline \multirow{2}{*}{ Month } & \multirow{2}{*}{$\begin{array}{l}\text { Number of } \\
\text { measurements }\end{array}$} & \multicolumn{4}{|c|}{ Monthly precipitation (inches) } \\
\hline & & Minimum & Median & Mean & $\overline{\text { Maximum }}$ \\
\hline \multicolumn{6}{|c|}{ TAYLOR PRECIPITATION GAGE (SITE R4) ${ }^{1}$} \\
\hline October & 4 & .31 & 1.47 & 1.50 & 2.73 \\
\hline November & 4 & .14 & .42 & .51 & 1.06 \\
\hline December & 4 & .05 & .40 & .36 & .59 \\
\hline January & 4 & .10 & .20 & .38 & .98 \\
\hline February & 4 & .15 & .41 & .40 & .64 \\
\hline March & 4 & .38 & .41 & .56 & 1.02 \\
\hline April & 4 & .19 & .43 & .62 & 1.44 \\
\hline May & 4 & .62 & 1.66 & 2.26 & 5.09 \\
\hline June & 4 & .37 & .98 & 1.23 & 2.59 \\
\hline July & 4 & .43 & 1.42 & 1.38 & 2.24 \\
\hline August & 5 & .43 & 2.78 & 2.01 & 3.43 \\
\hline September & 5 & 0 & .52 & .43 & 1.02 \\
\hline
\end{tabular}

${ }^{1}$ Site number on plate 1.

Monthly precipitation data from four sites operated year round at the Maneuver Site (p1. 1) from August 1983 through September 1987 were averaged for comparison with the 40-year (1947-87) mean monthly precipitation for the Las Animas County Airport (fig. 3). Comparison of short-term and long-term precipitation records can help to characterize the temporal variability of the short-term precipitation record.

At the Las Animas County Airport and the Maneuver Site, monthly precipitation for November through March usually was less than 1 in. (fig. 3). Precipitation during this period usually results from frontal storms and occurs as low-intensity rainfall or snowfall.

Increased precipitation during April, May, and June indicates spring geographic circulation patterns that carry fast-moving frontal storms eastward over southern Colorado. Storms that occur during this period usually are of low to moderate intensity. Monthly precipitation during April through June usually was less than 2 in.; however, monthly precipitation greater than 2 in. is not uncommon (fig. 3). Monthly precipitation at the Bent Canyon precipitation gage (site R1) (p1. 1) for May 1987 was 6.17 in. (tables 3 and 4); when compared to precipitation data for the Las Animas County Airport, the May 1987 monthly precipitation of 6.17 in. was exceeded once at the Airport during the period of record (1947-87).

Precipitation during July through September largely results from convective storms. Monthly precipitation during July through September at the Las Animas County Airport usually was greater than 1 in. Comparison of precipitation records at the Maneuver Site with long-term records from the Las Animas County Airport indicates generally drier than long-term conditions for July and September and wetter than long-term conditions for August (fig. 3). 

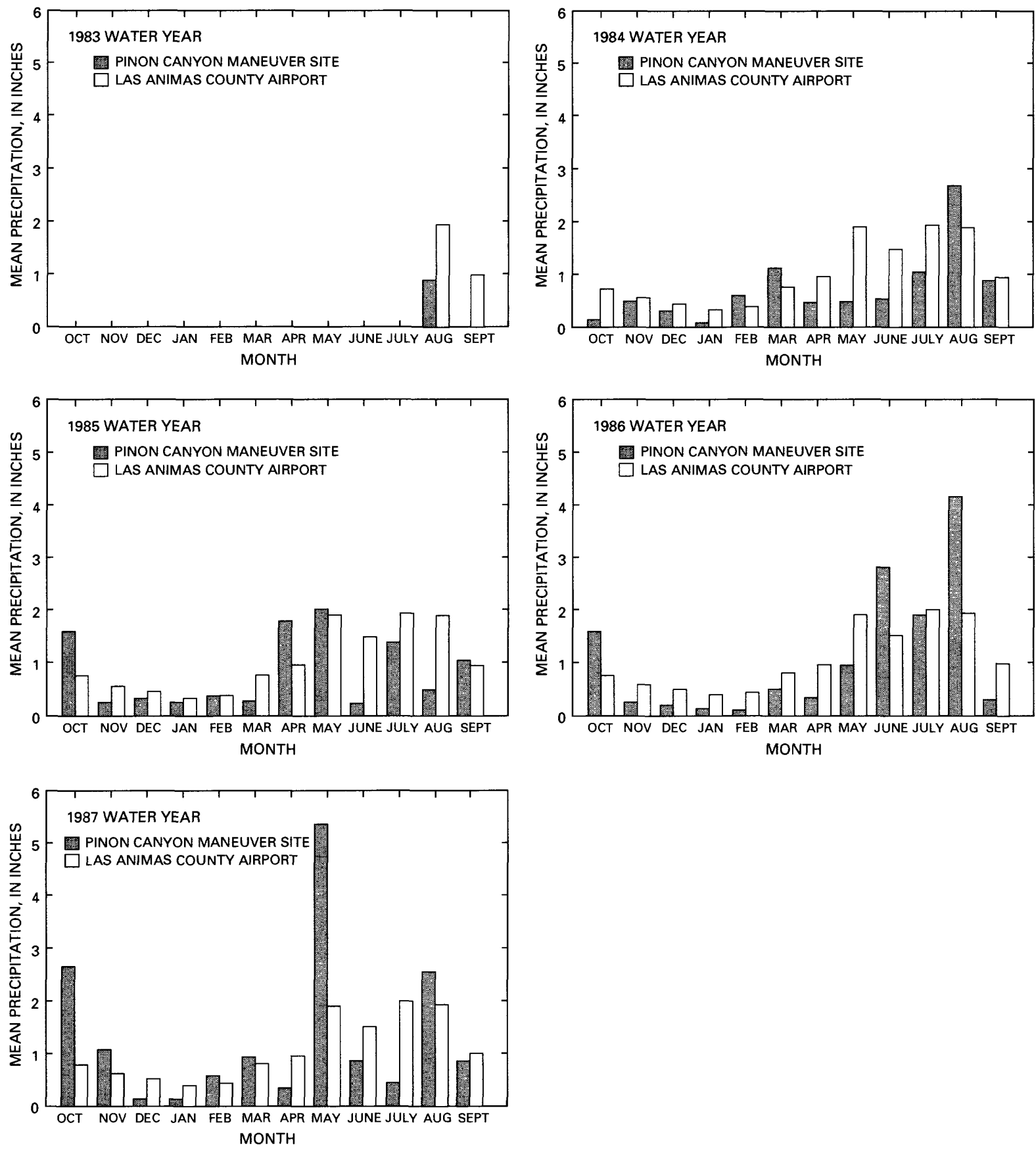

Figure 3.--Monthly mean precipitation at the Pinon Canyon Maneuver Site from August 1983 through September 1987 compared to 40-year (1947-87) mean monthly precipitation at the Las Animas County Airport. 
Spatial variations in precipitation can be determined by comparing ranges and median values of precipitation at the four precipitation gages (table 4 ). Spatial variations also can be determined by examination of monthly and annual totals of precipitation at the four precipitation gages (table 3). An example of the spatial variability for a particular convective storm in the Taylor Arroyo drainage basin is shown in figure 4. Precipitation for the August 3, 1987, storm in the Taylor Arroyo drainage basin ranged from 0.30 to 3.0 in. and had an area-weighted daily mean precipitation of 1.25 in. In this example, the largest measured volume of precipitation was in the northeastern parts of the Taylor Arroyo drainage basin.

\section{Change in Precipitation at the Maneuver Site Between Pre- and Postmaneuver Periods}

Evaluation of changes in precipitation between pre- and postmaneuver periods needs to precede the evaluation of the effects of military maneuvers on streamflow and water-quality properties and constituents for streams draining the Maneuver Site. Monthly mean precipitation at the Maneuver Site from August 1983 through September 1987 was calculated as the mean of monthly precipitation at the four precipitation gages ( 1.1 ; table 3 ). Monthly mean precipitation data for the pre- and postmaneuver periods were compared using box plots. A box plot is used to show more detail near the extremes of the data. It is a useful tool for visually examining the central tendency and dispersion of a group of data and is useful especially for comparing two or more groups of data. An example of a box plot is shown in figure 5 . First, the median value is plotted as a horizontal line. The 25 th and 75 th percentiles are the lower and upper ends that are used to draw a box. The box represents the interquartile range. Vertical lines extend to 1.5 times the interquartile range. Outliers within 1.5 to 3.0 times the interquartile range are shown as " $x$ " and as "." for far out values greater than 3.0 times the interquartile range (Martin and Crawford, 1987).

To avoid serial correlation in the daily precipitation data, monthly mean precipitation was used in the following analysis. Hydrologic data usually do not have a normal distribution and are often skewed. Therefore when doing statistical analyses, the data commonly are transformed to follow a normal distribution, or non parametric statistical techniques are used that are less sensitive to the skewed distribution. Change in monthly mean precipitation at the Maneuver Site between the pre- and postmaneuver periods was evaluated using the non parametric seasonal rank-sum test (Crawford and others, 1983). An assumption of the seasonal rank-sum test is that the data are independent, that is, having no correlation with time. The independence of monthly mean precipitation data for three time periods was tested by evaluating the Spearman correlation coefficient (rho) (Iman and Conover, 1983). The results of the Spearman rho test for independence are listed in table 5; monthly mean precipitation data for each period used in this analysis are independent at a 0.05 -significance level. 


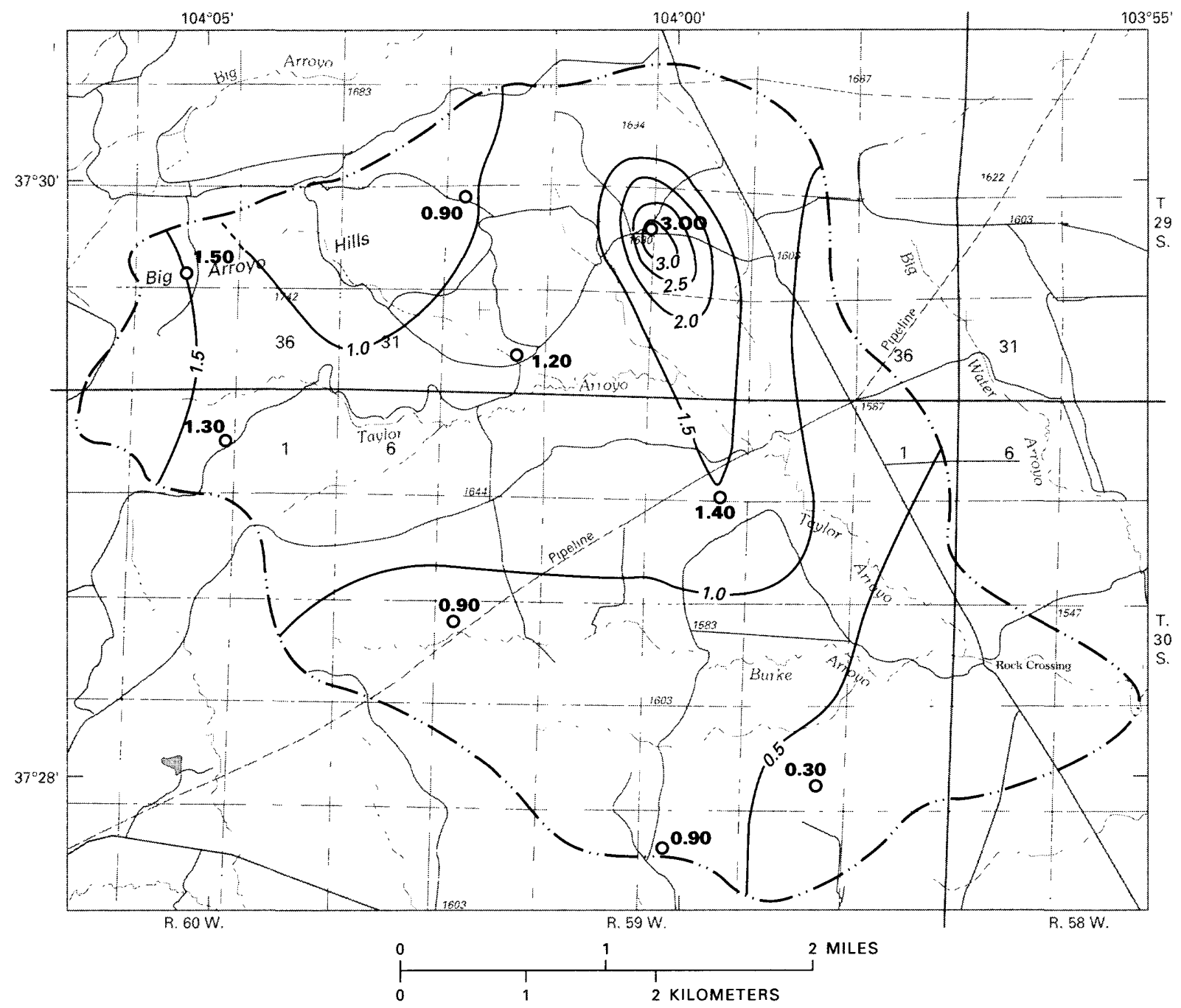

EXPLANATION

- 0.5 - LINE OF EQUAL PRECIPITATION, IN INCHES

DRAINAGE BASIN BOUNDARY

PRECIPITATION GAGE

AND NUMBER IS TOTAL

PRECIPITATION, IN INCHES

Figure 4.--Precipitation for August 3, 1987, in the Taylor Arroyo drainage basin. (See plate 1 for location of basin.)

For the purposes of understanding any changes in streamflow between pre- and postmaneuver periods, change in precipitation between the periods is analyzed using the seasonal rank-sum test. The seasonal rank-sum test includes temporal variations in data and is used to test for changes between periods that are separated by some specific event. The start of military maneuvers on July 29, 1985, is the specific event that separates data collected in and near the Maneuver Site into pre- and postmaneuver periods. 


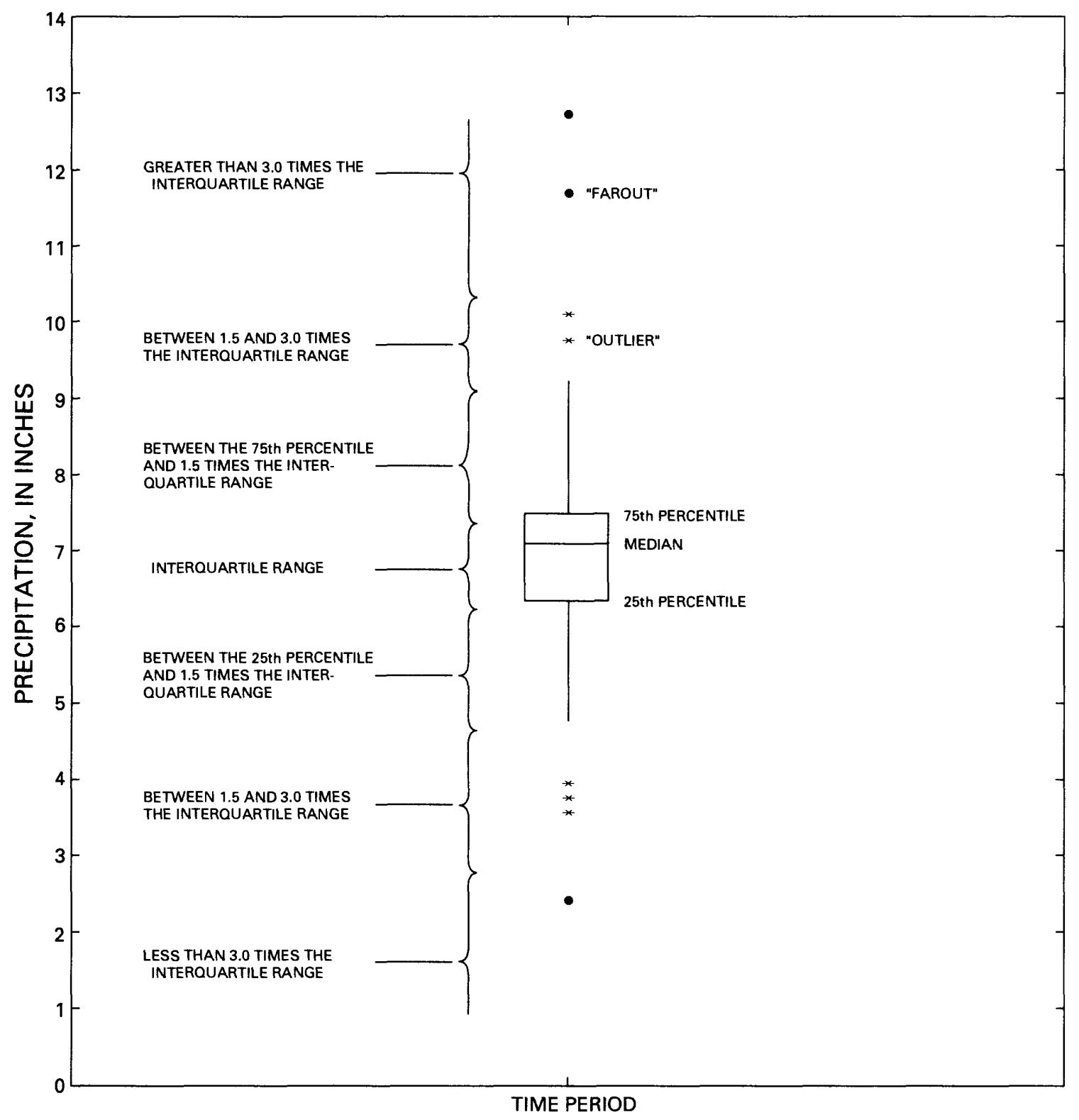

Figure 5.--Example of a box plot (modified from Martin and Crawford, 1987).

For the purposes of analyzing monthly data, the premaneuver period ends July 31, 1985. The significance of change in monthly mean precipitation between pre- and postmaneuver periods is determined by testing the null hypothesis, $\mu_{1}=\mu_{2}$. The null hypothesis is tested by calculating a test statistic and determining its associated p-value. As described by Iman and Conover (1983, p. 217), "The p-value associated with an observed value of a test statistic is the smallest level of significance that would have allowed the null hypothesis to be rejected." 
Table 5.--P-values for the Spearman correlation coefficient (rho) for monthly mean precipitation, monthly streamflow, and monthly mean specific-conductance data for selected sites in and near the Pinon Canyon Maneuver Site

\begin{tabular}{|c|c|c|c|c|}
\hline \multirow{2}{*}{$\begin{array}{l}\text { Site number } \\
\text { on plate } 1 \\
\text { and station name } \\
\text { in table } 2\end{array}$} & \multirow{2}{*}{$\begin{array}{l}\text { Type of } \\
\text { monthly } \\
\text { data }\end{array}$} & \multicolumn{3}{|c|}{$\begin{array}{l}\text { Probability of a greater } \\
\text { Spearman's rho } 1\end{array}$} \\
\hline & & $\begin{array}{l}\text { November } \\
\text { through } \\
\text { March }\end{array}$ & $\begin{array}{l}\text { April } \\
\text { through } \\
\text { June }\end{array}$ & $\begin{array}{l}\text { July } \\
\text { through } \\
\text { October }\end{array}$ \\
\hline $\begin{array}{l}\text { Average of precipi- } \\
\text { tation sites R1, } \\
\text { R2, R3, and R4. }\end{array}$ & Precipitation & 0.60 & 0.38 & 0.42 \\
\hline $\begin{array}{l}\text { S3 Van Bremer Arroyo } \\
\text { near Model. }\end{array}$ & $\begin{array}{l}\text { Streamflow } \\
\text { Specific conductance }\end{array}$ & $0^{.01}$ & $\begin{array}{l}.41 \\
.06\end{array}$ & $\begin{array}{l}.36 \\
.03\end{array}$ \\
\hline $\begin{array}{l}\text { S3 Van Bremer Arroyo } \\
\text { near Model minus } \\
\text { irrigation-return } \\
\text { flow. }\end{array}$ & $\begin{array}{l}\text { Streamflow } \\
\text { Specific conductance }\end{array}$ & $\begin{array}{l}.01 \\
.02\end{array}$ & $\begin{array}{l}.09 \\
.20\end{array}$ & $\begin{array}{l}.12 \\
.86\end{array}$ \\
\hline $\begin{array}{l}\text { S4 Purgatoire River } \\
\text { near Thatcher. }\end{array}$ & $\begin{array}{l}\text { Streamflow } \\
\text { Specific conductance }\end{array}$ & $\begin{array}{l}.52 \\
.53\end{array}$ & $\begin{array}{l}.91 \\
.32\end{array}$ & $\begin{array}{l}.53 \\
.21\end{array}$ \\
\hline $\begin{array}{l}\text { S6 Lockwood Canyon } \\
\text { Creek near Thatcher. }\end{array}$ & $\begin{array}{l}\text { Streamflow } \\
\text { Specific conductance }\end{array}$ & $\begin{array}{l}.77 \\
.80\end{array}$ & $\begin{array}{l}.21 \\
.96\end{array}$ & $0^{.23}$ \\
\hline $\begin{array}{l}\text { S8 Chacuaco Creek at } \\
\text { mouth, near Timpas. }\end{array}$ & $\begin{array}{l}\text { Streamflow } \\
\text { Specific conductance }\end{array}$ & $\begin{array}{l}\left(\begin{array}{l}2 \\
(3)\end{array}\right) \\
\left({ }^{3}\right)\end{array}$ & $\begin{array}{l}.01 \\
(3)\end{array}$ & $\begin{array}{l}.31 \\
(3)\end{array}$ \\
\hline $\begin{array}{l}\text { S10 Purgatoire River } \\
\text { at Rock Crossing, } \\
\text { near Timpas. }\end{array}$ & $\begin{array}{l}\text { Streamflow } \\
\text { Specific conductance }\end{array}$ & $\begin{array}{l}.91 \\
.34\end{array}$ & $\begin{array}{l}.91 \\
.12\end{array}$ & $\begin{array}{l}.64 \\
.69\end{array}$ \\
\hline $\begin{array}{l}\text { The sum of sites } \mathrm{S} 1 \text {, } \\
\mathrm{S} 5, \mathrm{~S} 7 \text {, and } \mathrm{S} 9 \text {. }\end{array}$ & $\begin{array}{l}\text { Streamflow } \\
\text { Specific conductance }\end{array}$ & $\begin{array}{l}\left(\begin{array}{l}2 \\
3\end{array}\right) \\
\left({ }^{\prime}\right)\end{array}$ & $\begin{array}{l}.40 \\
\left({ }^{3}\right)\end{array}$ & $\begin{array}{l}.86 \\
\left({ }^{3}\right)\end{array}$ \\
\hline
\end{tabular}

${ }^{1}$ Probabilities of a Spearman's rho $>0.05$ indicate that data are independent at a 0.05-significance level.

${ }^{2}$ Streamflow period November through March not used in analysis.

${ }^{3}$ Spearman's correlation coefficient not determined.

Monthly mean precipitation data were classified into three groups (time periods), November through March (period 1), April through June (period 2), and July through October (period 3). Groups were selected based on the type and intensity of precipitation that usually occurs during a period. Precipitation for October through March usually is of low intensity or occurs as snowfall. During April through June, precipitation usually is a result of fast-moving frontal storms, and precipitation during July through September usually results from convective storms. Monthly mean precipitation was larger during the postmaneuver period (fig. 6, table 3); however, no significant difference $(p>0.05)$ was detected $(p=0.79)$ in monthly mean precipitation between the pre- and postmaneuver periods. 

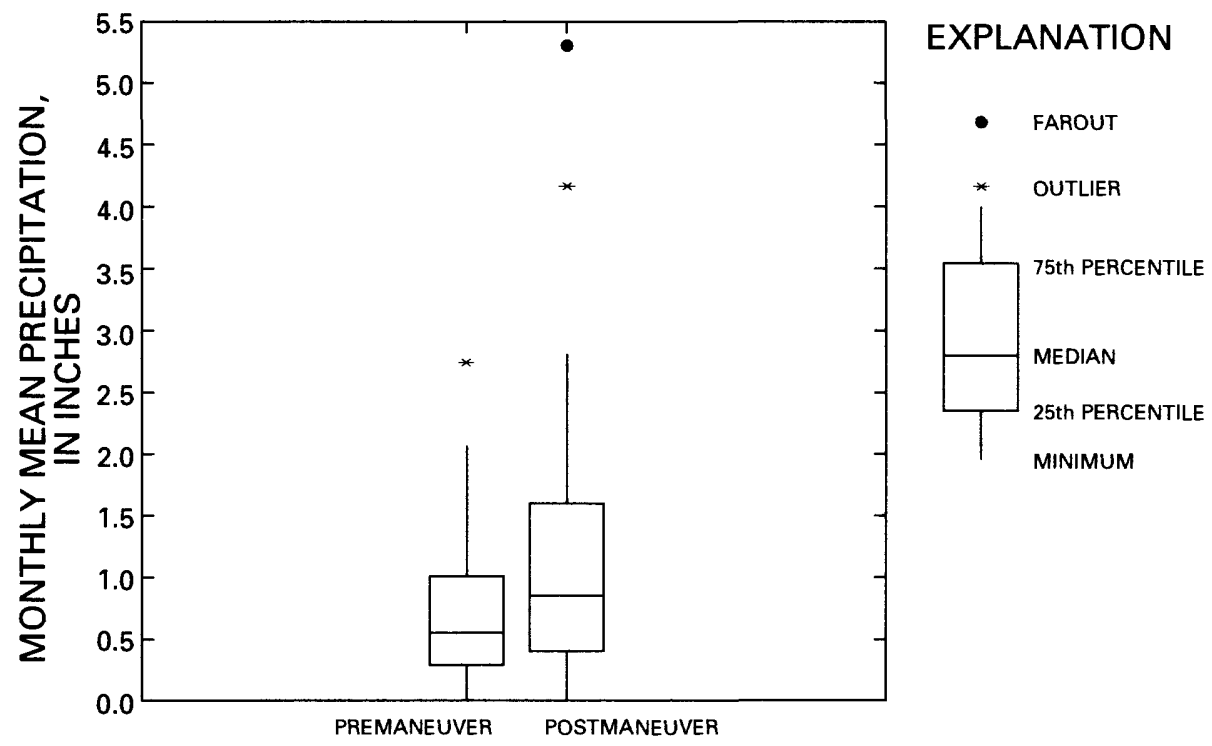

Figure 6.--Monthly mean precipitation at the Pinon Canyon Maneuver Site for pre- and postmaneuver periods.

Analysis of annual precipitation data indicated an increase in annual precipitation from water years 1984 through 1987 (table 3). Further analysis of the monthly mean precipitation data indicated that the increase in annual precipitation is due to more than average precipitation for certain months. Monthly mean precipitation for August and October 1986 and for May 1987 at the Maneuver Site far exceeded the 40-year mean for those months at the Las Animas County Airport (fig. 3).

\section{Effects of Precipitation on Vegetation}

Vegetal cover at the Maneuver Site protects the soil surface from the energy of rain-splash erosion. In addition, dead and decaying plant material improves infiltration capacity and soil structure through addition of organic material. Reseeding of vegetation, a method of rehabilitating lands disturbed by military maneuvers, will be affected by the timing and quantity of precipitation.

Precipitation during October through March has minimal effect on seedling establishment and plant growth. However, the presence or absence of adequate precipitation during these months determines antecedent soil-moisture conditions for the growing season. Precipitation during the spring growing period, April through June, is necessary for the germination and seedling establishment of vegetation. The temporal distribution of precipitation during the spring growing period may affect the germination and establishment of reseeded vegetation. For example, during water year 1985, monthly precipitation for April, May, and June was $1.81,2.03$, and 0.23 in. (table 3). Less than average precipitation in June may adversely affect seedlings that emerge during the wet period of April and May. Precipitation is necessary during the summer growing period, July through September, to maintain the growth of spring vegetation and emerging summer vegetation. 
The spring growing period is a critical time in determining the species composition of vegetation at the Maneuver Site (R.S. Shaw, Colorado State University, written commun., 1987). Early spring (April) precipitation is necessary for germination of cool-season annual vegetation and initiation of cool-season perennial plants; late spring (May and June) precipitation is necessary for growth of warm-season vegetation. For example, the total spring precipitation during water year 1987 exceeded the 40-year mean monthly precipitation at the Las Animas County Airport (fig. 3). As a result, 1987 vegetation surveys indicate an increase in cool-season annual grasses and warm-season annual forbs compared to the 1985 and 1986 surveys (R.S. Shaw, written commun., Colorado State University, 1987).

Shaw (written commun., 1987) noted a major shift in species composition of vegetation in areas affected by military maneuvers from perennial warmseason grasses (particularly blue grama) to annual cool-season grasses (six-weeks grass and little barley) and warm-season forbs (sunflower, Russianthistle, and kochia). Annual vegetation becomes established in areas disturbed by military maneuvers and provides some protection for the soil surface. Establishment of annual vegetation is dependent on at least average precipitation. Therefore, at a particular time in the year, during periods of drought, such as the summer 1985 (fig. 3), establishment of annual vegetation would be limited, and the temporary cover provided by such vegetation would not be available to protect the soil from the erosive forces of wind and water.

\section{EFFECTS OF MILITARY MANEUVERS ON STREAMFLOW}

The change in land use at the Maneuver Site may affect the volume of streamflow in tributaries draining the Maneuver Site. Increases in streamflow from the Maneuver Site may result in increased discharge of dissolved solids and suspended sediment to the Purgatoire River. The following discussion of streamflow in and near the Maneuver Site includes an analysis of the effects of military maneuvers on streamflow of the Maneuver Site. Analysis of temporal and spatial characteristics and change in streamflow between pre- and postmaneuver periods and summary statistics for streamflow at streamflowgaging stations in and near the Maneuver Site are included in this section.

\section{Contribution of Tributary Streamflow to the Purgatoire River}

Streamflow data were reported by von Guerard and others (1987, p. 33) for water years 1984 and 1985 for the following tributaries in and near the Maneuver Site, Van Bremer Arroyo near Model (site S3); Taylor Arroyo below Rock Crossing, near Thatcher (site S5); Lockwood Canyon Creek near Thatcher (site S6); Red Rock Canyon Creek at mouth, near Thatcher (site S7); Chacuaco Creek at mouth, near Timpas (site S8); and Bent Canyon Creek at mouth, near Timpas (site S9) (table 2; pl. 1). During water years 1984 through 1987 (table 6), Purgatoire River tributaries that drain the Maneuver Site (sites S3, S5, S6, S7, and S9) had a combined streamflow of about 9,000 acre-ft, or about 4.0 percent of the total streamflow of the Purgatoire River at Rock Crossing, near Timpas (site S10). However, because of instream transit 
Table 6.--streamflow at streamflow-gaging stations in and near the Pinon Canyon Maneuver site for water years 1984 through 1987

\begin{tabular}{|c|c|c|c|c|c|c|c|c|c|c|c|c|}
\hline \multirow{2}{*}{$\begin{array}{c}\text { Site } \\
\text { number } \\
\text { on } \\
\text { plate } \\
1\end{array}$} & \multicolumn{2}{|c|}{ U.S. Geological Survey } & \multicolumn{5}{|c|}{$\begin{array}{l}\text { Streamflow, in acre-feet, } \\
\text { for indicated period }\end{array}$} & \multicolumn{5}{|c|}{$\begin{array}{l}\text { Percent of streamflow at } \\
\text { Purgatoire River at Rock Crossing, } \\
\text { near Timpas, for indicated period }\end{array}$} \\
\hline & $\begin{array}{l}\text { Station } \\
\text { number } \\
\text { (table 2) }\end{array}$ & $\begin{array}{c}\text { Station } \\
\text { name } \\
(\text { table } 2)\end{array}$ & $\begin{array}{l}\text { Water } \\
\text { year } \\
1984\end{array}$ & $\begin{array}{l}\text { Water } \\
\text { year } \\
1985\end{array}$ & $\begin{array}{l}\text { Water } \\
\text { year } \\
1986\end{array}$ & $\begin{array}{l}\text { Water } \\
\text { year } \\
1987\end{array}$ & Total & $\begin{array}{l}\text { Water } \\
\text { year } \\
1984\end{array}$ & $\begin{array}{l}\text { Water } \\
\text { year } \\
1985\end{array}$ & $\begin{array}{l}\text { Water } \\
\text { year } \\
1986\end{array}$ & $\begin{array}{l}\text { Water } \\
\text { year } \\
1987\end{array}$ & Total \\
\hline S1 & 07120620 & $\begin{array}{l}\text { Big Arroyo near } \\
\text { Thatcher. }\end{array}$ & 84 & 102 & 20 & 17 & 223 & (1) & $(1)$ & $(1)$ & $(1)$ & $\left.{ }^{1}\right)$ \\
\hline s3 & 07126200 & $\begin{array}{l}\text { Van Bremer Arroyo } \\
\text { near Model. }\end{array}$ & 605 & 1,790 & 2,340 & 1,180 & 5,910 & 1.14 & 5.44 & 4.86 & 1.32 & 2.65 \\
\hline 54 & 07126300 & $\begin{array}{l}\text { Purgatoire River } \\
\text { near Thatcher. }\end{array}$ & 52,000 & 34,100 & 44,900 & 92,900 & 224,000 & 298.1 & 2104 & 293.3 & 2104 & 100 \\
\hline S5 & 07126325 & $\begin{array}{l}\text { Taylor Arroyo } \\
\text { below Rock } \\
\text { Crossing, } \\
\text { near Thatcher. }\end{array}$ & 130 & 51 & 109 & 253 & 543 & 0.24 & 0.16 & 0.23 & 0.28 & 0.24 \\
\hline S6 & 07126390 & $\begin{array}{l}\text { Lockwood Canyon } \\
\text { Creek near } \\
\text { Thatcher. }\end{array}$ & 225 & 18 & 102 & 321 & 666 & .42 & .05 & .21 & .36 & .30 \\
\hline S7 & 07126415 & $\begin{array}{l}\text { Red Rock Canyon } \\
\text { Creek at mouth, } \\
\text { near Thatcher. }\end{array}$ & 275 & 7.9 & 608 & 298 & 1,190 & .52 & .02 & 1.26 & .33 & .53 \\
\hline S8 & 07126470 & $\begin{array}{l}\text { Chacuaco Creek at } \\
\text { mouth, near } \\
\text { Timpas. }\end{array}$ & 532 & 606 & 1,450 & 1,020 & 3,610 & 1.00 & 1.84 & 3.01 & 1.14 & 1.62 \\
\hline s9 & 07126480 & $\begin{array}{l}\text { Bent Canyon Creek } \\
\text { at mouth, near } \\
\text { Timpas. }\end{array}$ & 654 & 0 & 33 & .40 & 687 & 1.23 & 0 & .07 & 0 & .31 \\
\hline 510 & 07126485 & $\begin{array}{l}\text { Purgatoire River } \\
\text { at Rock Cross- } \\
\text { ing, near } \\
\text { Timpas. }\end{array}$ & 53,000 & 32,900 & 48,100 & 89,300 & 223,000 & $(1)$ & $(1)$ & $\left.{ }^{1}\right)$ & $(1)$ & $(1)$ \\
\hline
\end{tabular}

${ }^{1}$ Not applicable.

2Differences most likely attributable to measurement error of streamflow.

losses, less than the 9,000 acre-ft of streamflow measured at tributaries draining the Maneuver Site likely reaches the Purgatoire River. Instream transit loss in the Taylor Arroyo drainage basin was determined to be about $6.2 \mathrm{acre}-\mathrm{ft} / \mathrm{mi}$ of stream channel (von Guerard and others, 1987, p. 41). About 72 percent of the streamflow originating in the upper parts of the Taylor Arroyo drainage basin during August 1985 was lost to instream transit losses prior to reaching the downstream streamflow-gaging station (site S5). There are no measurements or gage records on the seeps and springs that occur below the streamflow-gaging stations on streams tributary to the Purgatoire River. However, based on periodic observations, the contribution of these seeps and springs to streamflow at site $\mathrm{S} 10$ is small, if any. It is assumed that 50 percent of the streamflow for water years 1984 through 1987 from tributaries draining the Maneuver Site reaches site $\mathrm{S} 10$; this percentage would be only about 2.0 percent of the flow at site 510 , or less than the measurement error of streamflow records at site $\mathrm{S} 10$. 
About 64 percent of the tributary streamflow from the Maneuver Site (including streamflow for site S1) for water years 1984 through 1987 was discharged from Van Bremer Arroyo, near Model (site S3) (table 6). During water years 1984 through 1987 , about 3,700 acre-ft, or about 63 percent, of the total streamflow at site $S 3$ resulted from irrigation-return flow from farmland adjacent to the Maneuver Site. Irrigation-return flow was determined by analyzing daily streamflow at site S3. Streamflow greater than base streamflow $\left(>0.50 \mathrm{ft}^{3} / \mathrm{s}\right)$ that was unaffected by rainfall runoff was considered to be irrigation return flow. This return flow represents about 41 percent of the streamflow that flows from the Maneuver Site. The remainder of the tributary streamflow resulted from rainfall runoff and from base streamflow sustained by ground-water seepage.

The main tributary inflow to the Purgatoire River, Chacuaco Creek at mouth, near Timpas (site S8), located between streamflow-gaging stations Purgatoire River near Thatcher (site S4) and Purgatoire River at Rock Crossing, near Timpas (site S10), does not originate on the Maneuver Site (table 2; pl. 1). Chacuaco Creek has a drainage area of $424 \mathrm{mi}^{2}$ (table 2), which is an area similar in size to the Maneuver Site. During water years 1984 through 1987, streamflow from Chacuaco Creek was 3,610 acre-ft, or about 1.6 percent, of the streamflow at site S10 (table 6). Chacuaco Creek is ephemeral, and all streamflow resulted from rainfall runoff.

\section{Streamflow in the Purgatoire River}

Elevation differences in the Purgatoire River basin cause climatic variations which, in turn, affect the streamflow. During years with average and above-average snowpack, 30 to 50 percent of the annual streamflow of the Purgatoire River occurs during April and May. During the rainfall-runoff period, May through October, flash floods occur intermittently. Releases from Trinidad Reservoir, located about $53 \mathrm{mi}$ upstream from the streamflow-gaging station Purgatoire River near Thatcher (site S4), affect streamflow on an intermittent basis.

Change from livestock grazing to military maneuvers at the Maneuver Site may increase streamflow contributions from the Maneuver Site to the Purgatoire River. Analysis of trends in streamflow for the Purgatoire River is useful for determining effects of streamflow from the Maneuver Site on streamflow in the Purgatoire River.

Streamflow data for water years 1968 through 1987 for the Purgatoire River near Thatcher (site S4) (table 2; pl. 1) were examined for trends by using locally weighted regression scatter-plot smoothing (lowess curve) (Chambers and others, 1983, p. 94). The lowess-curve procedure uses weighted least squares to fit a line to a set of points on a scatter plot. A smoothed point is calculated by determining how $y$ depends on $x$ within a segment of the scatter plot. The data point (y) at the center of a particular segment is assigned the greatest weight, and the weight function for data points decreases smoothly as $x$ moves away from the center point ( $y)$. This procedure is repeated for each data point at the center of a segment until a smoothed data set is calculated. 
Trend analysis of streamflow at site 54 is representative of the Purgatoire River in the vicinity of the Maneuver Site because of the similarity of streamflow records at the Purgatoire River near Thatcher (site S4) and the Purgatoire River at Rock Crossing, near Timpas (site S10) (table 6). An increasing monotonic trend in annual streamflow apparently has occurred at site S4 since 1974 (fig. 7). The significance of this apparently increasing trend in annual streamflow was tested by evaluating the Spearman correlation coefficient (rho). The results of this trend test indicate that the increasing monotonic trend in annual streamflow (fig. 7) was significant (Spearman's rho $=0.53$ ) at the 0.05 significance level. Because of the long-term increasing trend in annual streamflow for the Purgatoire River in the vicinity of the Maneuver Site and because streamflow from the Maneuver Site is a small part of streamflow at site S10 (table 6), changes in streamflow in the Purgatoire River that result from military maneuvers are not likely to be detected.

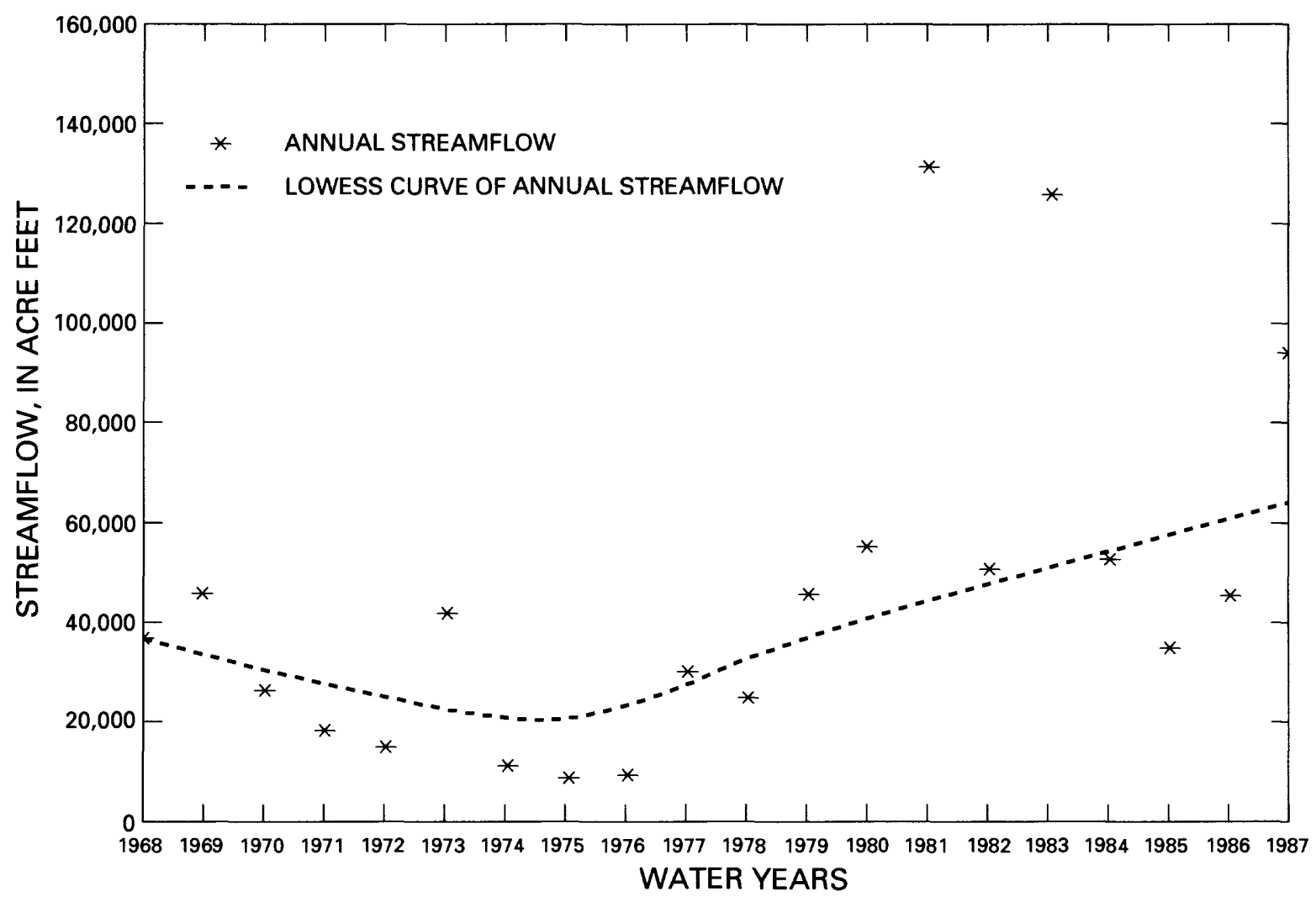

Figure 7.--Lowess curve of smoothed annual streamflow at the streamflowgaging station Purgatoire River near Thatcher (site S4) for water years 1968 through 1987.

Changes in streamflow in the Purgatoire River between pre- and postmaneuver periods were examined by using monthly streamflow data for the Purgatoire River near Thatcher (site S4) and the Purgatoire River at Rock Crossing, near Timpas (site S10) (pl. 1). Monthly streamflow data for the 1983 through 1987 water years at sites S4 and S10 are summarized in table 7. 
Table 7.--Summary statistics for monthly streamflow at streamflow-gaging stations in and near the Pinon Canyon Maneuver Site for pre- and postmaneuver periods

[Premaneuver period is October 1982 through July 1985; postmaneuver period is August 1985 through September 1987]

\begin{tabular}{|c|c|c|c|c|c|c|c|c|}
\hline \multirow{2}{*}{ Period } & \multirow{2}{*}{$\begin{array}{l}\text { Number } \\
\text { of } \\
\text { measure- } \\
\text { ments }\end{array}$} & \multicolumn{7}{|c|}{$\begin{array}{c}\text { Monthly streamflow } \\
(\text { acre-feet) }\end{array}$} \\
\hline & & Mean & $\begin{array}{l}\text { Standard } \\
\text { deviation }\end{array}$ & $\begin{array}{l}\text { Mini- } \\
\text { mum }\end{array}$ & $\begin{array}{l}25 \text { th per- } \\
\text { centile }\end{array}$ & Median & $\begin{array}{l}\text { 75th per- } \\
\text { centile }\end{array}$ & $\begin{array}{c}\text { Maxi- } \\
\text { mum }\end{array}$ \\
\hline
\end{tabular}

VAN BREMER ARROYO NEAR MODEL (SITE S3)

$\begin{array}{lcccccccc}\text { Premaneuver } & 34 & 61.9 & 138 & 1.92 & 7.97 & 10.6 & 15.6 & 559 \\ \text { Postmaneuver } & 26 & 152 & 257 & 6.80 & 11.7 & 37.7 & 101 & 982 \\ \text { Premaneuver }^{1} & 34 & 13.5 & 15.5 & 1.84 & 7.14 & 9.74 & 12.3 & 88.5 \\ \text { Postmaneuver }^{1} & 26 & 73.8 & 150 & 6.76 & 11.1 & 12.4 & 48.0 & 676\end{array}$

PURGATOIRE RIVER NEAR THATCHER (SITE S4)

$\begin{array}{lrrrrrrrr}\text { Premaneuver } & 34 & 6,100 & 8,810 & 1,650 & 2,180 & 2,740 & 5,650 & 45,400 \\ \text { Postmaneuver } & 26 & 5,480 & 7,350 & 974 & 2,330 & 2,940 & 5,476 & 36,400\end{array}$

LOCKWOOD CANYON CREEK NEAR THATCHER (SITE S6)

\begin{tabular}{|c|c|c|c|c|c|c|c|c|}
\hline Premaneuver & 27 & 10.6 & 23.2 & 0.0 & 0.73 & 1.78 & 7.91 & 95. \\
\hline Postmaneuver & 26 & 16.3 & 55.9 & 0 & .79 & 1.90 & 5.12 & 286 \\
\hline & & CUACO & EK AT & & TIMPAS & $(\mathrm{SITE} S 8)^{2}$ & & \\
\hline $\begin{array}{l}\text { Premaneuver } \\
\text { Postmaneuver }\end{array}$ & $\begin{array}{l}22 \\
26\end{array}$ & $\begin{array}{l}40.0 \\
105\end{array}$ & $\begin{array}{l}97.7 \\
221\end{array}$ & $\begin{array}{l}0 \\
0\end{array}$ & $\begin{array}{l}0 \\
0\end{array}$ & $\begin{array}{l}0 \\
0\end{array}$ & $\begin{array}{c}0 \\
93.2\end{array}$ & $\begin{array}{l}322 \\
886\end{array}$ \\
\hline
\end{tabular}

PURGATOIRE RIVER AT ROCK CROSSING, NEAR TIMPAS (SITE S10)

$\begin{array}{lllllllll}\text { Premaneuver } & 26 & 5,750 & 9,320 & 1,880 & 2,330 & 2,650 & 6,280 & 49,800 \\ \text { Postmaneuver } & 26 & 5,470 & 7,150 & 1,240 & 2,290 & 2,840 & 5,940 & 36,000\end{array}$

EPHEMERAL STREAMS ON THE MANEUVER SITE ${ }^{2,3}$

\begin{tabular}{lllllllll} 
Premaneuver & 18 & 84.4 & 231 & 0 & 0 & 7.17 & 71.6 & 995 \\
Postmaneuver & 16 & 86.3 & 154 & 0 & 0 & 23.3 & 89 & 555 \\
\hline
\end{tabular}

${ }^{1}$ Monthly streamflow at site $\mathrm{S} 3$ minus the effect of irrigation-return flow.

2Monthly streamflow data are for April through October.

${ }^{3}$ Monthly streamflow data are for April through October and are the summation of monthly streamflows for streamflow-gaging stations Big Arroyo near Thatcher (site S1); Taylor Arroyo below Rock Crossing, near Thatcher (site S5); Red Rock Canyon Creek at mouth, near Timpas (site S7); and Bent Canyon Creek at mouth, near Timpas (site S9). 
Monthly streamflow at sites $\mathrm{S} 4$ and $\mathrm{S} 10$ is similar; however, median monthly streamflow is higher at sites $\mathrm{S} 4$ and $\mathrm{S} 10$ during the postmaneuver period (table 7). The significance of change in monthly streamflow at each site, between the pre- and postmaneuver periods was determined by using the seasonal rank-sum test. Monthly streamflow data for each season at sites S4 and S10 are independent at a 0.05 significance level (table 5). This test indicated there was no significant difference $(p>0.05)$ in monthly streamflow at sites S4 and S10 between pre- and postmaneuver periods $(p=0.82$ and $p=0.65)$. Because there was no significant difference in monthly streamflow at sites 54 and 510 , any increase or decrease in streamflow from Chacuaco Creek at mouth near Timpas (site S8) ( 1.1 1) or in streamflow that resulted from military maneuvers at the Maneuver Site, cannot be detected by this analysis of streamflow data at sites $\mathrm{S} 4$ and $\mathrm{S} 10$. Because long-term streamflow for the Purgatoire River has been increasing (fig. 7), very large increases in streamflow from the Maneuver Site may be needed to detect any effects from military maneuvers on streamflow in the Purgatoire River.

Change in Streamflow for Chacuaco Creek at Mouth, Near Timpas, Between the Pre- and Postmaneuver Periods

Chacuaco Creek drains about 50 percent of the drainage area between the Purgatoire River near Thatcher (site S4) and the Purgatoire River at Rock Crossing, near Timpas (site S10) (table 2; p1. 1). To detect effects of military maneuvers on the Purgatoire River, streamflow in Chacuaco Creek was analyzed to distinguish the source of any changes that may have occurred in streamflow in the Purgatoire River.

Streamflow in Chacuaco Creek usually occurs in response to rainfall runoff during April through October. Summary statistics for monthly streamflow during the runoff period for the pre- and postmaneuver periods are listed in table 7. An increase in monthly median streamflow occurred at Chacuaco Creek at mouth, near Timpas (site S8), during the postmaneuver period. The test for change in monthly streamflow during runoff periods at site $\mathrm{S} 8$ was made by using the seasonal rank-sum test. Monthly streamflow data at site S8 are independent for July through October (period 3); however, there is some dependence between monthly streamflow data for April through June (period 2) (table 5). When there is some dependence in the monthly data, the significance level (alpha)--in this case, alpha $=0.05--$ is not exact and is considered approximate. There was no significant difference ( $p>0.05)$ in monthly streamflow between the pre- and postmaneuver periods $(p=0.26)$.

\section{Streamflow at the Maneuver Site}

Military maneuvers can denude large areas of vegetation and increase soil compaction. These effects could increase flow in streams draining the Maneuver Site. Except for Van Bremer Arroyo near Model (site S3) (table 2; pl. 1), which is affected by irrigation return flows from farmland adjacent to the Maneuver Site, most of the streamflow that originates from the Maneuver Site results from rainfall runoff. Trends in precipitation, increasing or decreasing, could affect trends in streamflow at the Maneuver Site. Because no substantial change in monthly precipitation occurred between pre- and postmaneuver periods (see discussion in "Change in Precipitation at the Maneuver 
Site Between Pre- and Postmaneuver Periods" section), any changes in streamflow that are unaffected by irrigation-return flows may be direct results of military maneuvers or conservation practices implemented by the U.S. Army.

Daily streamflow data for streams that drain the Maneuver Site are available at Big Arroyo near Thatcher (site S1); Van Bremer Arroyo near Model (site S3); Taylor Arroyo below Rock Crossing, near Thatcher (site S5); Lockwood Canyon Creek near Thatcher (site S6); Red Rock Canyon Creek at mouth, near Thatcher (site S7); and Bent Canyon Creek at mouth, near Timpas (site S9) (table 2; pl. 1). Sites S3 and $S 6$ are intermittent streams that flow in response to ground-water inflow and rainfall runoff. Sites S1, S5, S7, and S9 are ephemeral streams that flow only in response to rainfall runoff (table 2 ). To avoid serial correlation in the daily streamflow data, monthly streamflow was used in the following analysis.

Summary statistics of monthly streamflow data at the intermittent streamflow sites $\mathrm{S} 3$ and $\mathrm{S} 6$ are listed in table 7. During the postmaneuver period, median monthly streamflow for periods of all streamflow at site $\mathrm{S} 3$ was about 259 percent more than the median for the premaneuver period (table 7). However, median monthly streamflow without the effects of irrigation-return flow increased only about 27 percent for the same period.

Monthly streamflow at sites S3 and S6 were tested for change between preand postmaneuver periods by using the seasonal rank-sum test. There is some dependence in monthly streamflow data at site S3 during November through March (table 5); therefore, the significance level, alpha $=0.05$, is approximate. A significant increase $(p<0.05)$ occurred at site S3 for monthly streamflow that included the effects of irrigation-return flow and for monthly streamflow minus effects of irrigation-return flows $(p<.001$ and $p=0.002)$ (table 8$)$.

Table 8.--Overall and seasonal p-values from seasonal rank-sum test of monthly streamflow between pre- and postmaneuver periods at streamflowgaging stations Van Bremer Arroyo near Model (site S3) and Lockwood Canyon Creek near Thatcher (site S6)

[Premaneuver period, October 1982 through July 1985; postmaneuver period August 1985 through September 1987]

\begin{tabular}{|c|c|c|c|c|}
\hline \multirow{2}{*}{$\begin{array}{l}\text { Site number and } \\
\text { U.S. Geological } \\
\text { Survey station name } \\
\text { (p1. } 1 \text { and table 2) }\end{array}$} & \multirow[b]{2}{*}{$\begin{array}{l}\text { Overall } \\
\text { p-value }\end{array}$} & \multicolumn{3}{|c|}{ Seasonal p-values } \\
\hline & & $\begin{array}{l}\text { November } \\
\text { through } \\
\text { March }\end{array}$ & $\begin{array}{l}\text { April } \\
\text { through } \\
\text { June }\end{array}$ & $\begin{array}{l}\text { July } \\
\text { through } \\
\text { October }\end{array}$ \\
\hline S3, Van Bremer Arroyo near Mode1-- & $<0.001$ & 0.02 & 0.46 & 0.04 \\
\hline $\begin{array}{l}\text { S3, Van Bremer Arroyo near Mode1; } \\
\text { for months unaffected by } \\
\text { irrigation-return flow. }\end{array}$ & .002 & .02 & .07 & .09 \\
\hline $\begin{array}{l}\text { S6, Lockwood Canyon Creek near } \\
\text { Thatcher. }\end{array}$ & .82 & .51 & .45 & .84 \\
\hline
\end{tabular}


The p-values for the base streamflow period (November through March) and the summer streamflow period (July through October) (with irrigation return flow) indicate that a significant difference $(\mathrm{p}<0.05)$ occurred between pre- and postmaneuver monthly streamflow (table 8). The estimated volume of irrigation-return flows at site S3 increased during water year 1985 (fig. 8). The resulting increase in streamflow may be a result of water being stored in channel alluvium and streambanks during periods of irrigation return flow and its subsequent release during periods of base and summer streamflow.

No significant difference $(p>0.05)$ in monthly streamflow occurred at site S6 $(p=0.82)$. Analysis of $p$-values by season (table 8$)$ indicated there was no significant difference in monthly streamflow occurred for any season between the pre- and postmaneuver periods.

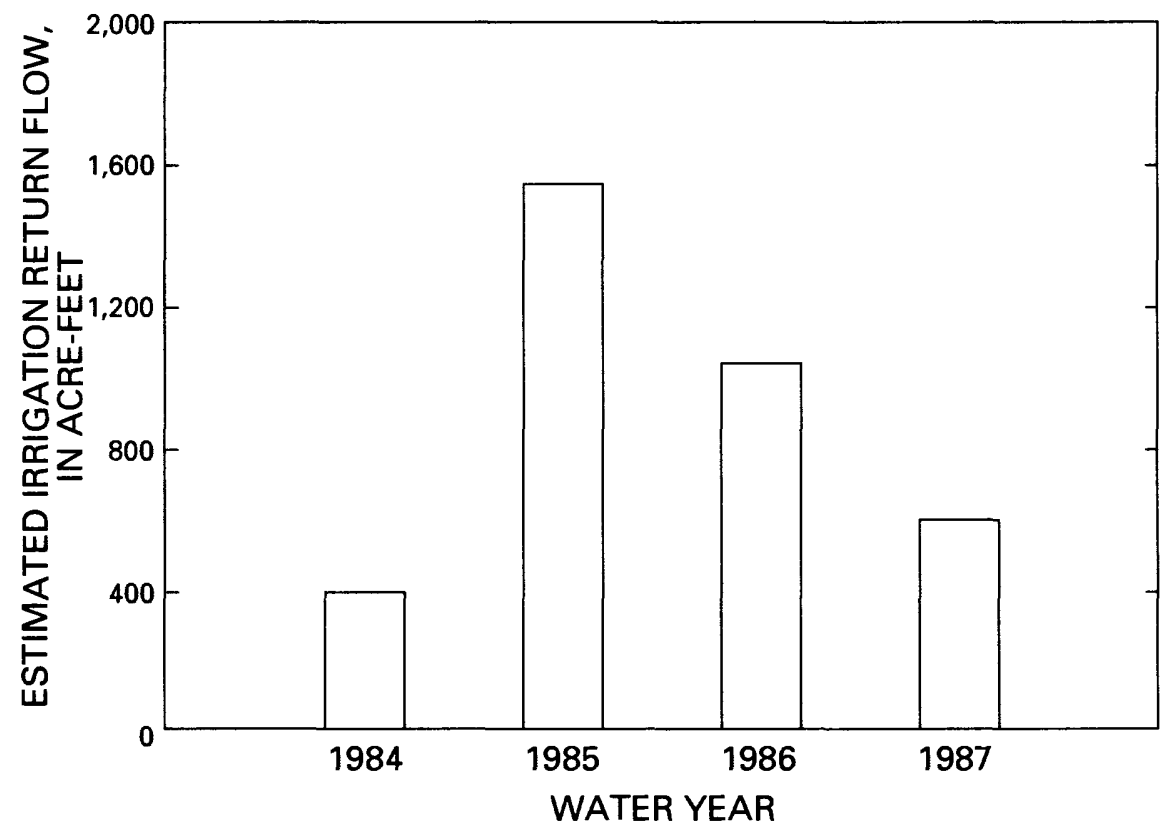

Figure 8.--Estimates of irrigation-return flow at the streamflow-gaging station Van Bremer Arroyo near Model (site S3) for water years 1984 through 1987. 
The infrequent occurrence of streamflow at ephemeral streams draining the Maneuver Site limits the amount of streamflow data available for analysis between pre- and postmaneuver periods for any one site (table 9). To have a large enough data base for statistical analysis, monthly streamflow for all gaged ephemeral streams, Big Arroyo near Thatcher (site S1); Taylor Arroyo below Rock Crossing, near Thatcher (site S5); Red Rock Canyon Creek at mouth, near Thatcher (site S7); and Bent Canyon Creek at mouth, near Timpas (site S9), were summed into one data set. Because streamflow at these sites usually occurs during May through October, monthly streamflow data for water years 1984 through 1987 for this runoff period were included in the following analysis. Because streamflow data are summed for sites S1, S5, S7, and S9 for pre- and postmaneuver periods, the statistical tests applied are for the overall distribution for all sites rather than for any particular site.

Table 9.--Number of streamflow events at ephemeral streamflow-gaging stations at the Pinon Canyon Maneuver Site for water years 1984 through 1987

\begin{tabular}{|c|c|c|c|c|c|c|}
\hline \multirow{2}{*}{$\begin{array}{c}\text { Site } \\
\text { number } \\
(\mathrm{p} 1.1)\end{array}$} & \multirow{2}{*}{$\begin{array}{l}\text { U.S. Geological Survey } \\
\text { station number and name } \\
\text { (table 2) }\end{array}$} & \multicolumn{5}{|c|}{$\begin{array}{l}\text { Number of streamflow events } \\
\text { during indicated water year }\end{array}$} \\
\hline & & 1984 & 1985 & 1986 & 1987 & Total \\
\hline $\mathrm{S} 1$ & $\begin{array}{l}07120620 \text { Big Arroyo } \\
\text { near Thatcher. }\end{array}$ & 2 & 2 & 1 & 2 & 7 \\
\hline S5 & $\begin{array}{l}07126325 \text { Taylor Arroyo } \\
\text { below Rock Crossing, } \\
\text { near Thatcher. }\end{array}$ & 2 & 3 & 6 & 3 & 14 \\
\hline S7 & $\begin{array}{l}07126415 \text { Red Rock Canyon } \\
\text { Creek at mouth, near } \\
\text { Thatcher. }\end{array}$ & 4 & 1 & 7 & 3 & 15 \\
\hline \multirow[t]{2}{*}{ S9 } & $\begin{array}{l}07126480 \text { Bent Canyon } \\
\text { Creek at mouth, } \\
\text { near Timpas. }\end{array}$ & 3 & 0 & 2 & 0 & 5 \\
\hline & Total & 11 & 6 & 16 & 8 & 41 \\
\hline
\end{tabular}

Summary statistics of combined monthly streamflow for all ephemeral sites for the pre- and postmaneuver periods are listed in table 7 . Combined monthly streamflow seems to have increased during the postmaneuver period. Combined monthly streamflow (April through 0ctober) for sites S1, S5, S7, and S9 was tested for change between the pre- and postmaneuver periods by using the seasonal rank-sum test. Combined monthly streamflow data for periods 2 (April through June) and 3 (July through 0ctober) at sites S1, S5, S7, and S9 were independent at a 0.05 -significance level (table 5). There was no significant ( $p>0.05)$ difference between combined monthly streamflows for the pre- and postmaneuver periods at sites S1, S5, S7, and S9 for the runoff period for water years 1984 through $1987(p=0.79)$. 


\section{Effects of Conservation Practices on Flood Frequency at the Maneuver Site}

In an attempt to contain soil erosion since the acquisition of the Maneuver Site, the U.S. Army built approximately 120 erosion-control dams throughout the Maneuver Site. The dams were built in all major drainage basins draining the Maneuver Site, except for the drainage basin upstream from Red Rock Canyon Creek at mouth, near Thatcher (site S7) (p1. 1). These erosion-control dams are in addition to the approximately 190 stock-watering reservoirs that were built prior to the U.S. Army's acquisition of the Maneuver Site.

Flood-frequency analysis for streams in and near the Maneuver Site was done by von Guerard and others (1987; p. 36) using regional estimating techniques described by McCain and Jarrett (1976) and Livingston and Minges (1987). In this analysis, the effective drainage area of all drainage basins was decreased by the drainage area upstream from the stock-watering reservoirs that were built prior to the U.S. Army's acquisition of the Maneuver Site. Effective drainage area is a significant independent variable used for estimating peak-flood discharges for selected recurrence intervals (McCain and Jarrett, 1976; Livingston and Minges, 1987). A decrease in effective drainage area might decrease the magnitude of estimated peak-flood discharges presented in von Guerard and others (1987, p. 40). However, increased soil compaction and loss of vegetal cover could cause increases in peak-flood discharges.

Recomputed estimates of peak-flow discharges estimated by von Guerard and others (1987, p. 40), using smaller effective drainage areas to include the effects of the newly constructed erosion-control dams, are listed in table 10. The recomputed estimates of peak-flood discharges are 0 to 40 percent less than earlier estimates.

Table 10.--selected drainage-basin characteristics, estimates of flood magnitude for solected recurrence intervals, percent difference from premaneuver land-use estimates of flood wagnitude, and recorded peak discharge for period of record for streamf low-gaging stations along streams draining the pinon Canyon maneuver site

$\left[\mathrm{mi}^{2}\right.$, square mile; $\mathrm{ft} / \mathbf{m i}^{\mathrm{i}}$, feet per $m i l e ; \mathrm{ft}^{3} / \mathrm{s}$, cubic feet per second]

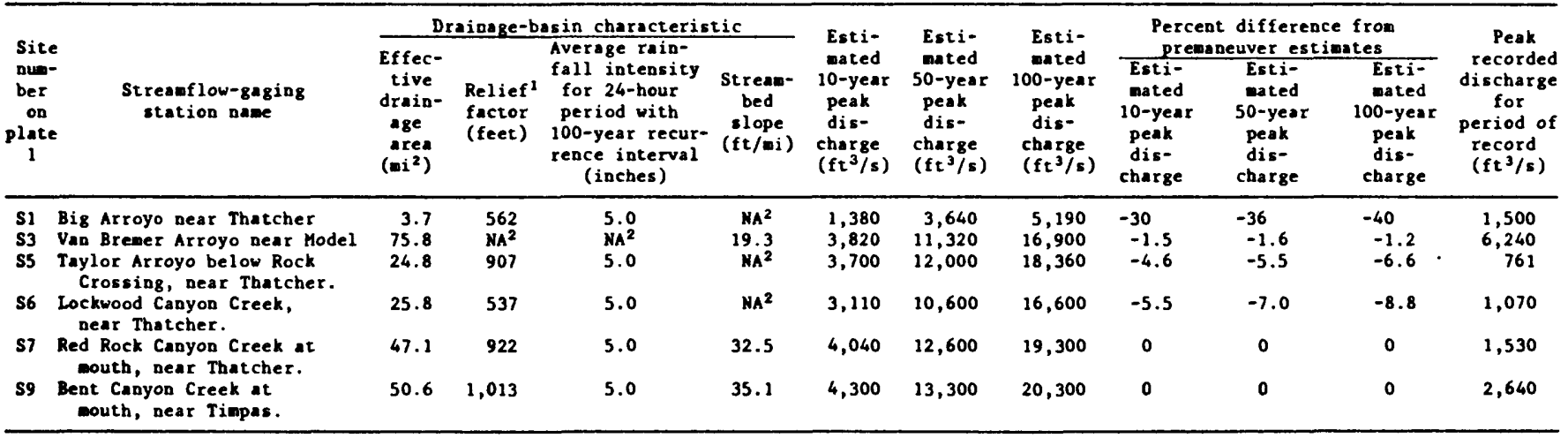

${ }^{1}$ Relief factor is the difference in elevation between the lowest and highest points in the drainage basin.

2Not used in estimatiog peak-flood discharge. 


\section{EFFECTS OF MILITARY MANEUVERS ON SURFACE-WATER QUALITY}

The change in land use at the Maneuver Site resulted in local concerns about the effects that military maneuvers might have on the surface water of the area and, consequently, about the effects on water quality of the Purgatoire River. The Maneuver Site is located about 58 river miles upstream from the confluence of the Arkansas and Purgatoire Rivers. Changes in water quality, particularly an increase in dissolved-solids concentrations that resulted from military maneuvers, could affect downstream agricultural water users. Although no changes were detected in streamflow between the pre- and postmaneuver periods for the Purgatoire River and tributaries that drain the Maneuver Site, concentrations of dissolved and suspended constituents may have increased as a result of military maneuvers. The following discussion of the effects of military maneuvers on surface-water quality includes instream water-quality standards and summary statistics of water-quality constituents and properties for pre- and postmaneuver periods.

Instream Water-Quality Standards for the Purgatoire River

The Colorado Department of Health, Water Quality Control Commission, has classified the section of the Purgatoire River that is downstream from Trinidad to its confluence with the Arkansas River as a class 2 warm-water aquatic-life stream. This water-quality classification is assigned to streams in which the variety of biological life forms is primarily limited by streamflow and streambed characteristics. Stream classifications are assigned to protect existing species and to encourage the establishment of more sensitive species that are compatible with existing streamflow and streambed characteristics (Colorado Department of Health, 1982).

Chemical properties and constituents included in the Colorado Department of Health (1982) instream water-quality standards are included in analysis of periodic water-quality samples at the Purgatoire River near Thatcher (site S4) and the Purgatoire River at Rock Crossing, near Timpas (site 10) (p1. 1). These measured properties and constituents are presented in the time-series plots of figures 9 and 10 , which also depict the instream standard for each property and constituent.

All measured dissolved-oxygen concentrations at sites S4 and S10 were greater than the minimum instream standard (figs. 9a and 10a). There is an instream water-quality standard for dissolved nitrite as nitrogen; however, concentrations of dissolved nitrite plus nitrate as nitrogen were measured. (Hereinafter, these terms are referred to as dissolved nitrite and dissolved nitrite plus nitrate.) Graphs of dissolved nitrite plus nitrate indicate that, during water years 1983 through 1987, the instream standard for dissolved nitrite may have been exceeded 10 times at the Purgatoire River near Thatcher (site S4) and 11 times at the Purgatoire River below Rock Crossing, near Timpas (site S10) (figs. $9 \mathrm{~b}$ and $10 \mathrm{~b}$ ). Dissolved nitrogen in surface water usually is not in the form of nitrite; therefore, most of the dissolved nitrite plus nitrate in surface water is assumed to be in the form of dissolved nitrate. Probable sources of dissolved nitrate in the Purgatoire River basin are farming and ranching activities. 

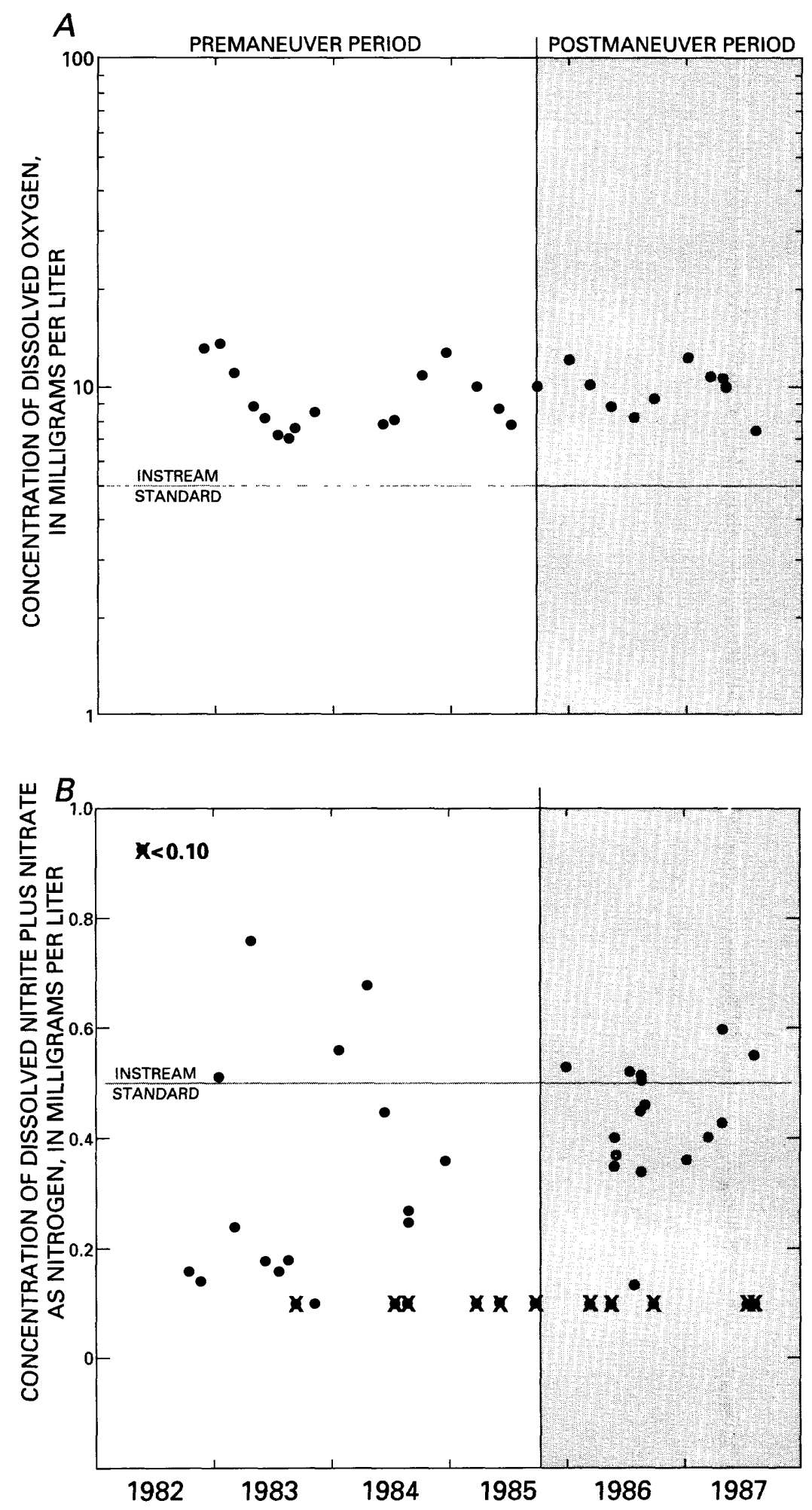

Figure 9.--Selected chemical properties and constituents and instream water-quality standards (Colorado Department of Health, 1982) for the streamflow-gaging station Purgatoire River near Thatcher (site S4) for water years 1983 through 1987: $A$, dissolved oxygen; and $B$, dissolved nitrite plus nitrate as nitrogen. 

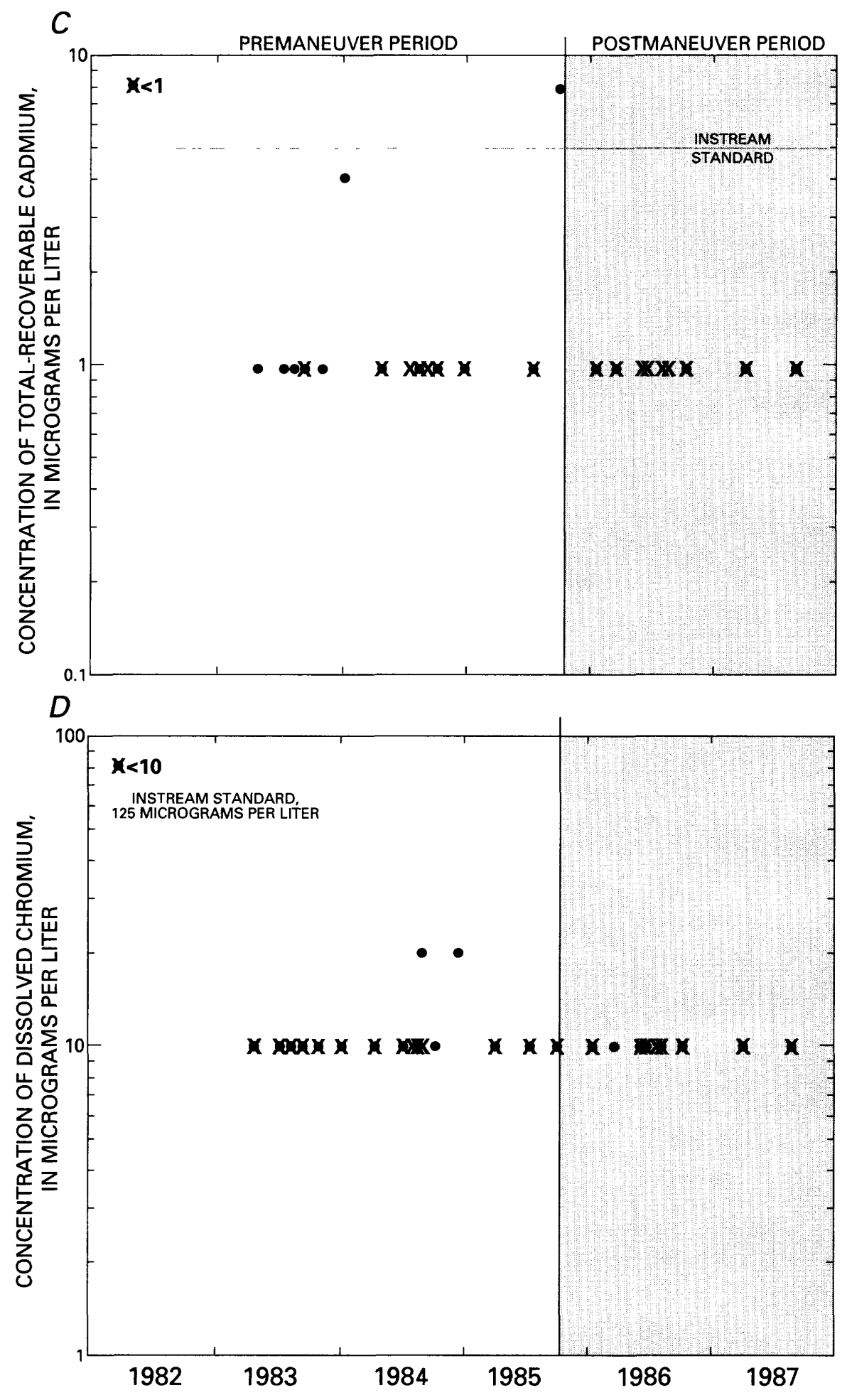

Figure 9.--Selected chemical properties and constituents and instream water-quality standards (Colorado Department of Health, 1982) for the streamflow-gaging station Purgatoire River near Thatcher (site S4) for water years 1983 through 1987: C, total-recoverable cadmium; and $D$, dissolved chromium--Continued. 


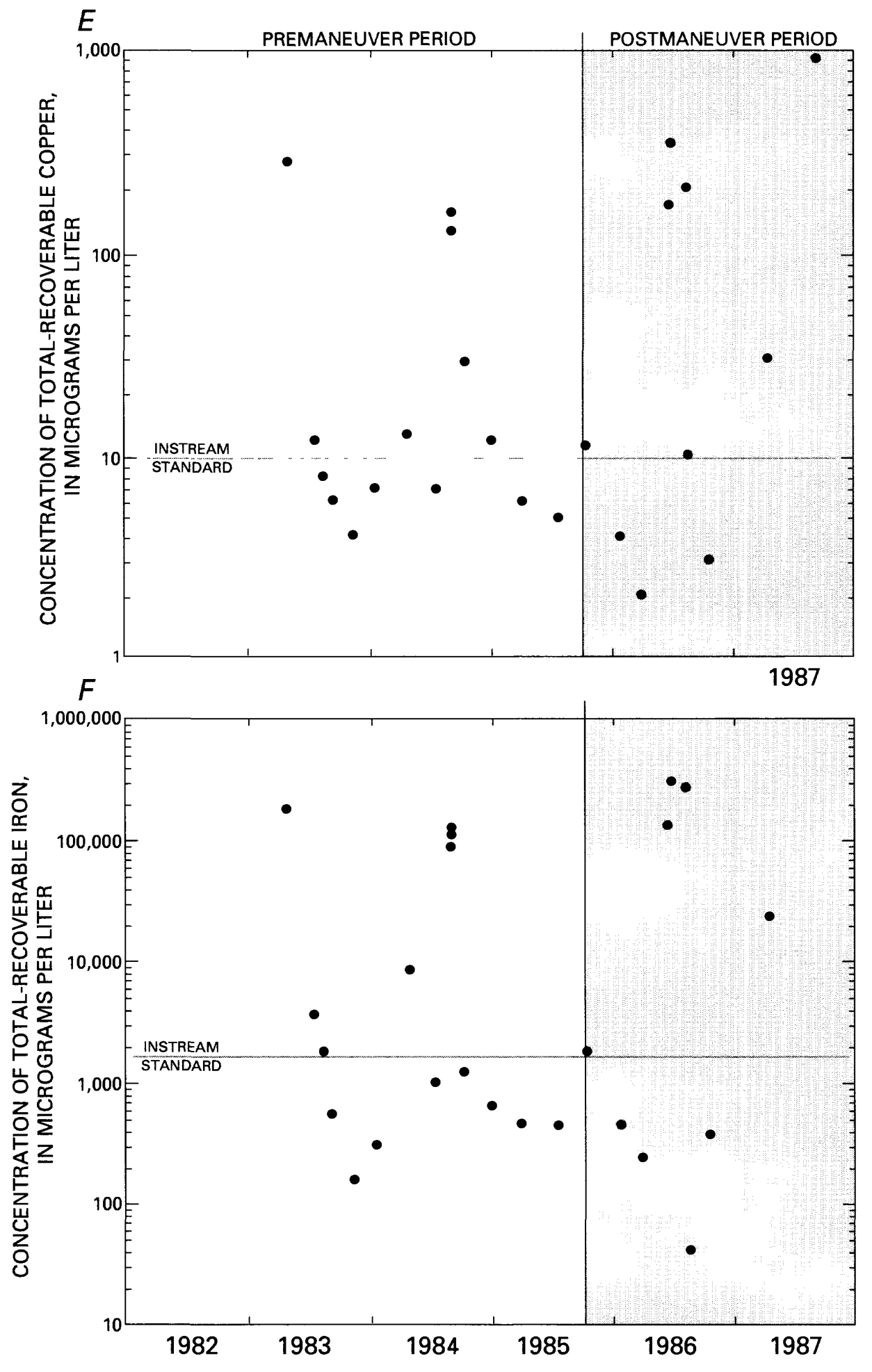

Figure 9.--Selected chemical properties and constituents and instream water-quality standards (Colorado Department of Health, 1982) for the streamflow-gaging station Purgatoire River near Thatcher (site S4) for water years 1983 through 1987: $E$, total-recoverable copper; and $F$, total-recoverable iron--Continued. 

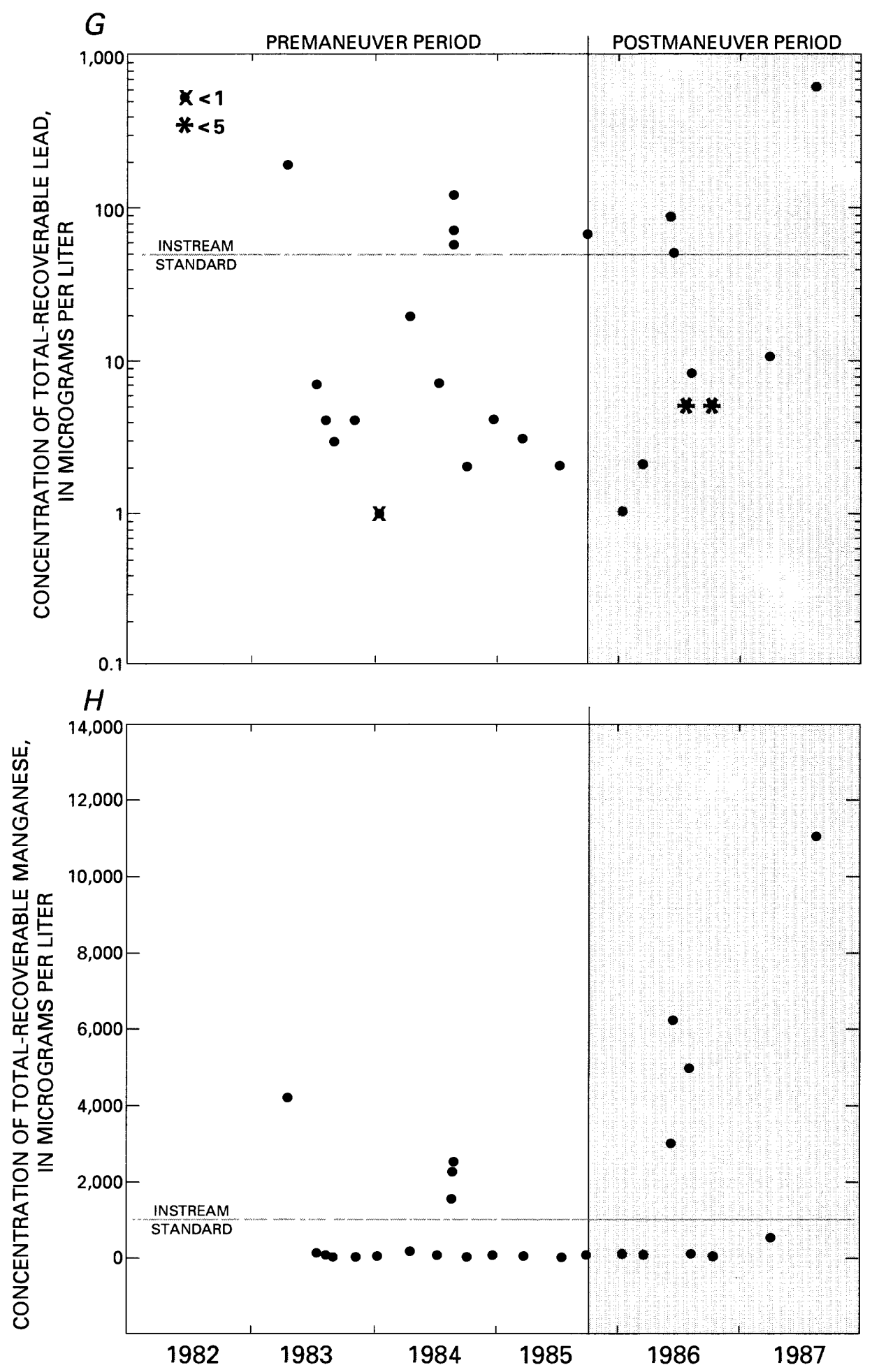

Figure 9.--Selected chemical properties and constituents and instream water-quality standards (Colorado Department of Health, 1982) for the streamflow-gaging station Purgatoire River near Thatcher (site S4) for water years 1983 through 1987: G, total-recoverable lead; and $H$, total-recoverable manganese--Continued. 

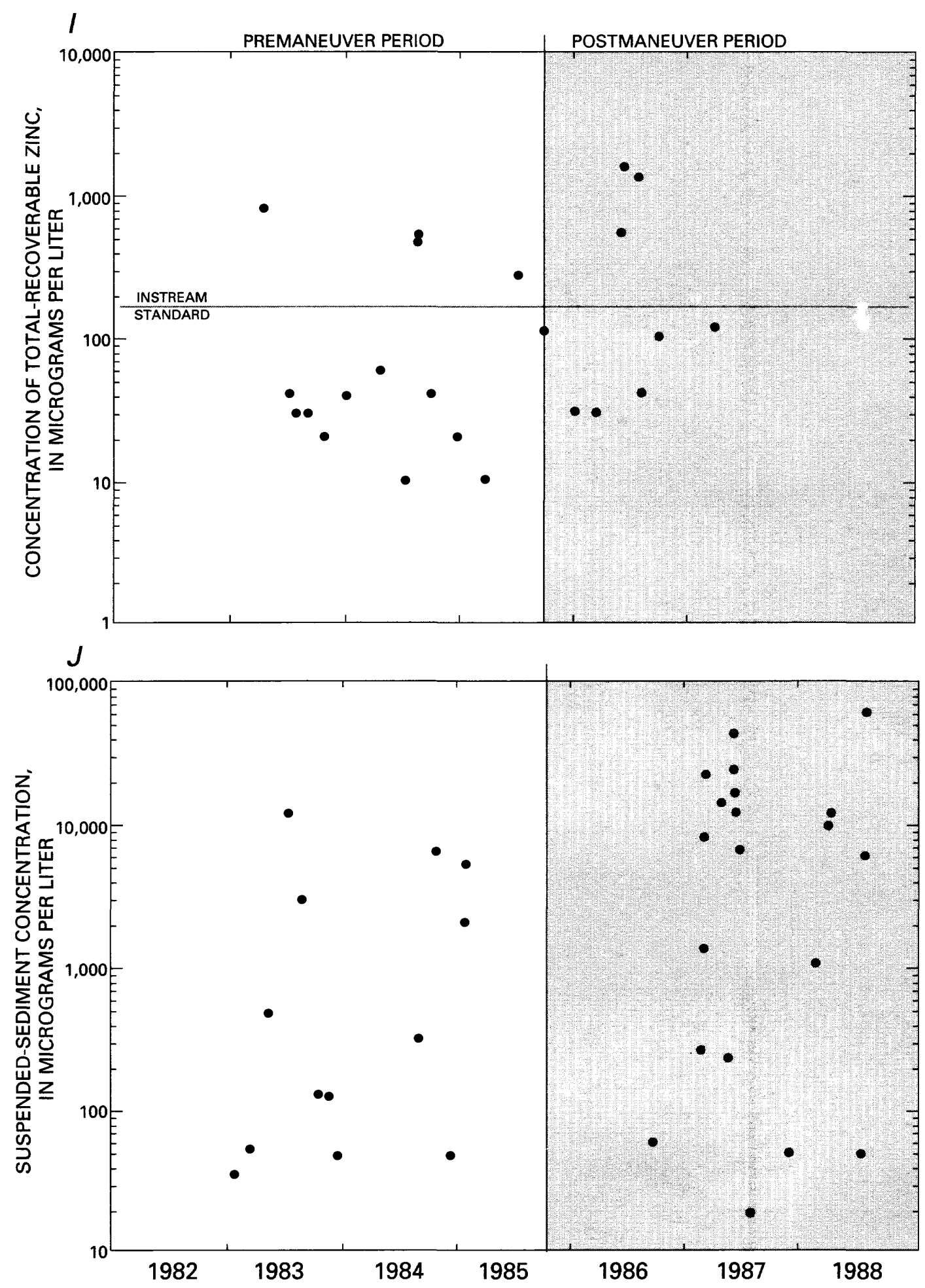

Figure 9.--Selected chemical properties and constituents and instream water-quality standards (Colorado Department of Health, 1982) for the streamflow-gaging station Purgatoire River near Thatcher (site S4) for water years 1983 through 1987: I, Total-recoverable zinc; and $J$, suspended-sediment concentration--Continued. 

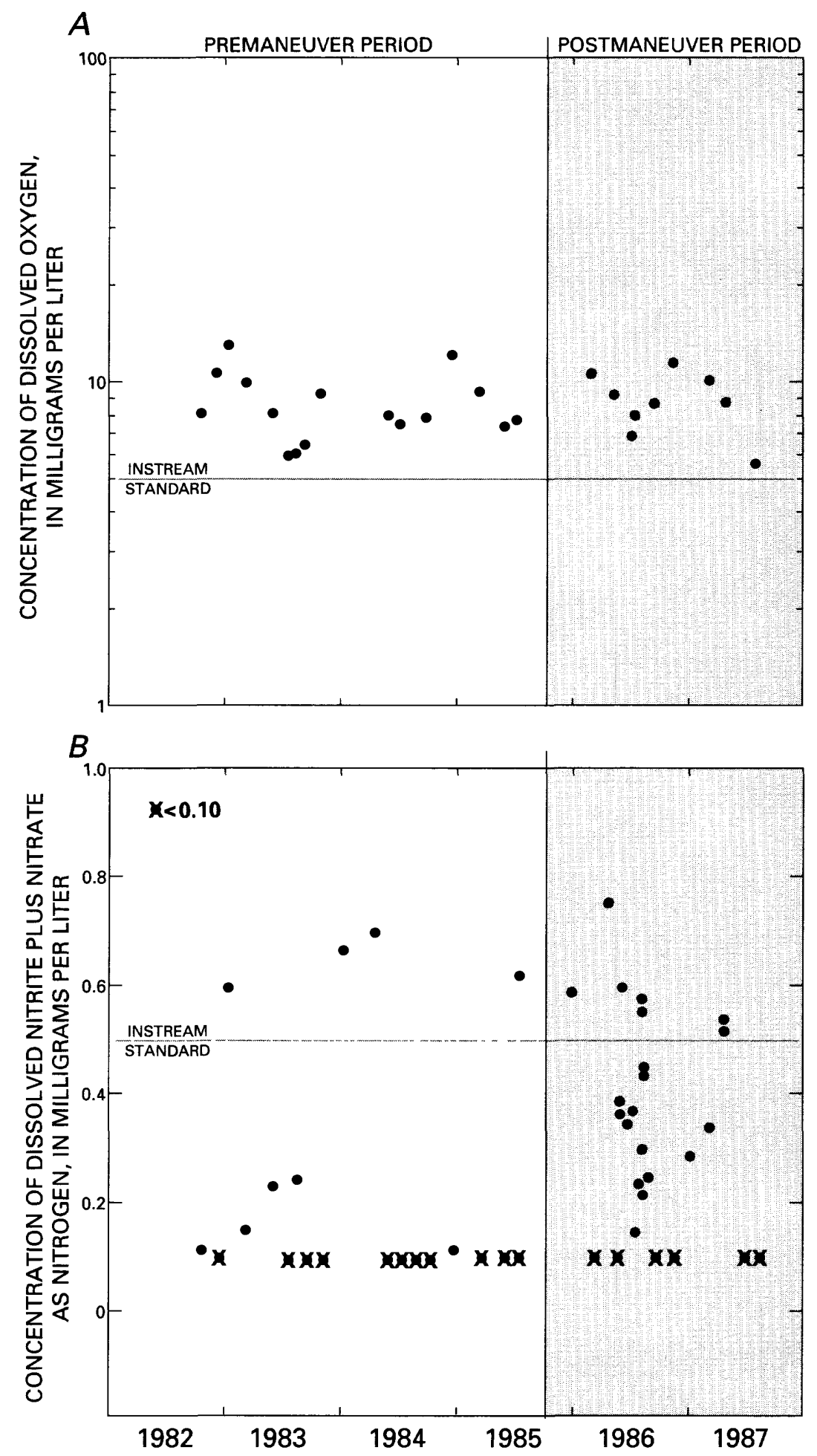

Figure 10.--Selected chemical properties and constituents and instream water-quality standards (Colorado Department of Health, 1982) for the streamflow-gaging station Purgatoire River at Rock Crossing, near Timpas (site S10), for water years 1983 through 1987: $\boldsymbol{A}$, dissolved oxygen; and $B$, dissolved nitrite plus nitrate as nitrogen. 

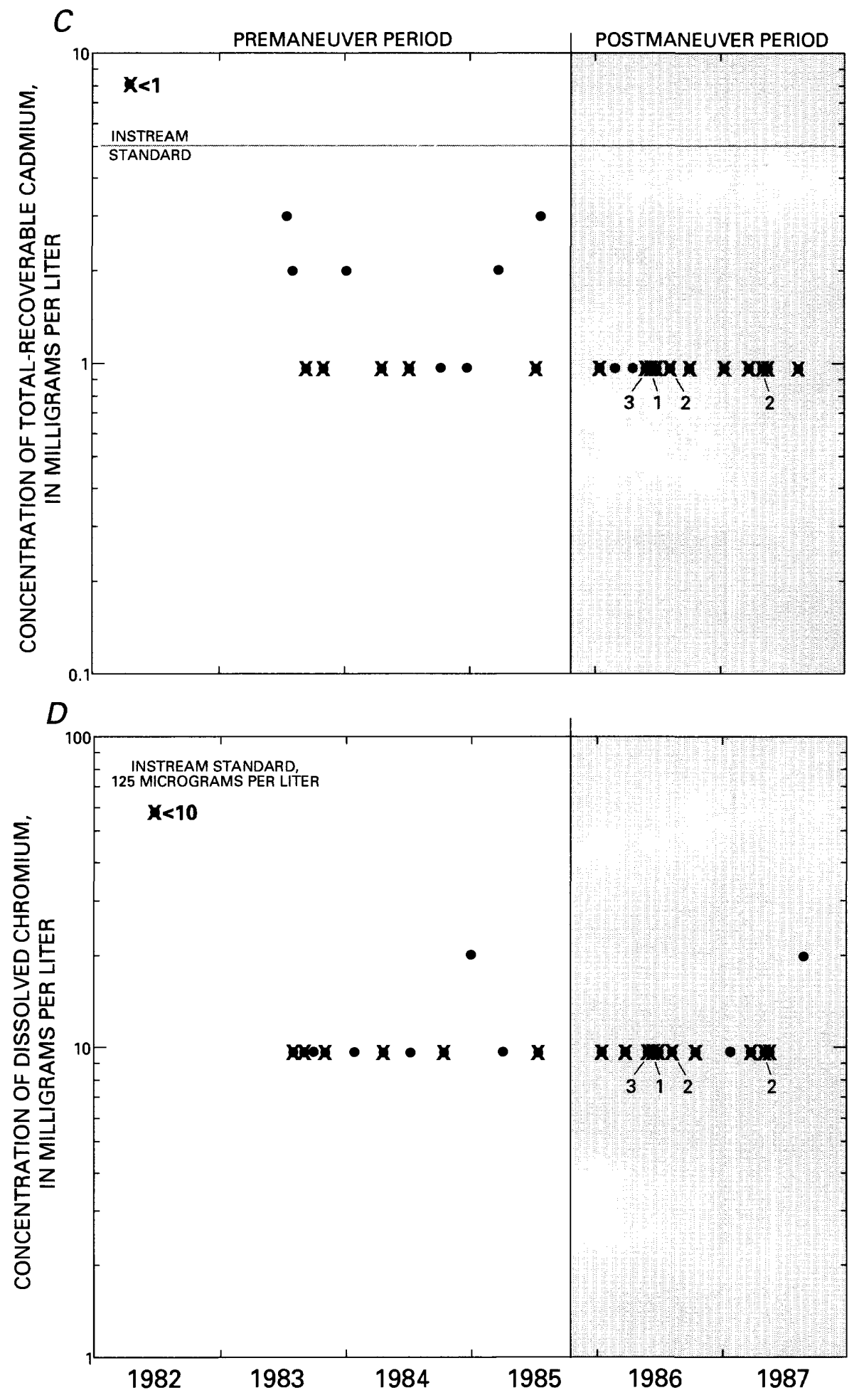

Figure 10.--Selected chemical properties and constituents and instream water-quality standards (Colorado Department of Health, 1982) for the streamflow-gaging station Purgatoire River at Rock Crossing, near Timpas (site S10), for water years 1983 through 1987: C, total-recoverable cadmium; and $D$, dissolved chromium--Continued. 

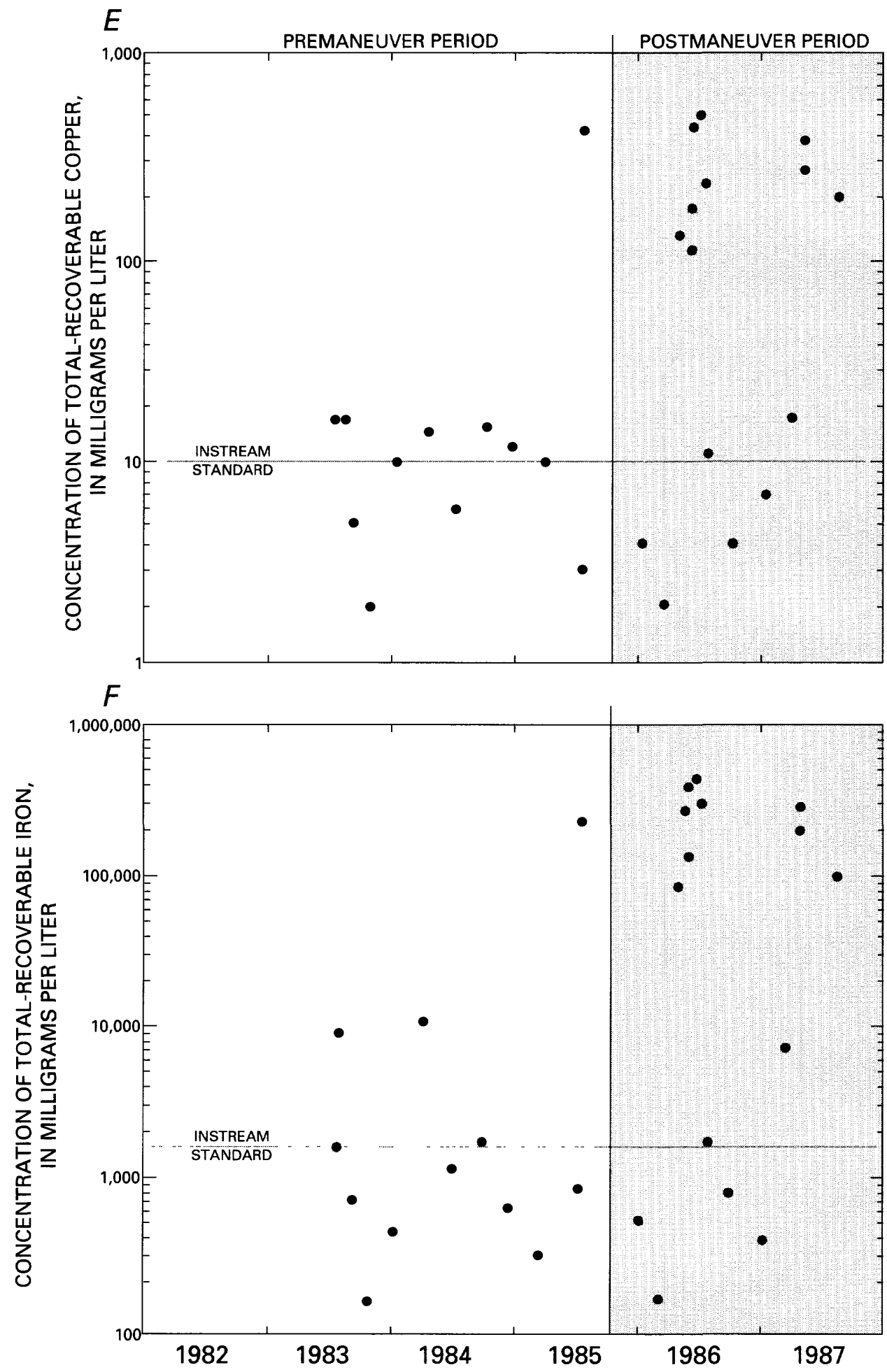

Figure 10.--Selected chemical properties and constituents and instream water-quality standards (Colorado Department of Health, 1982) for the streamflow-gaging station Purgatoire River at Rock Crossing, near Timpas (site S10), for water years 1983 through 1987: $E$, total recoverable copper; and $F$, total-recoverable iron--Continued. 

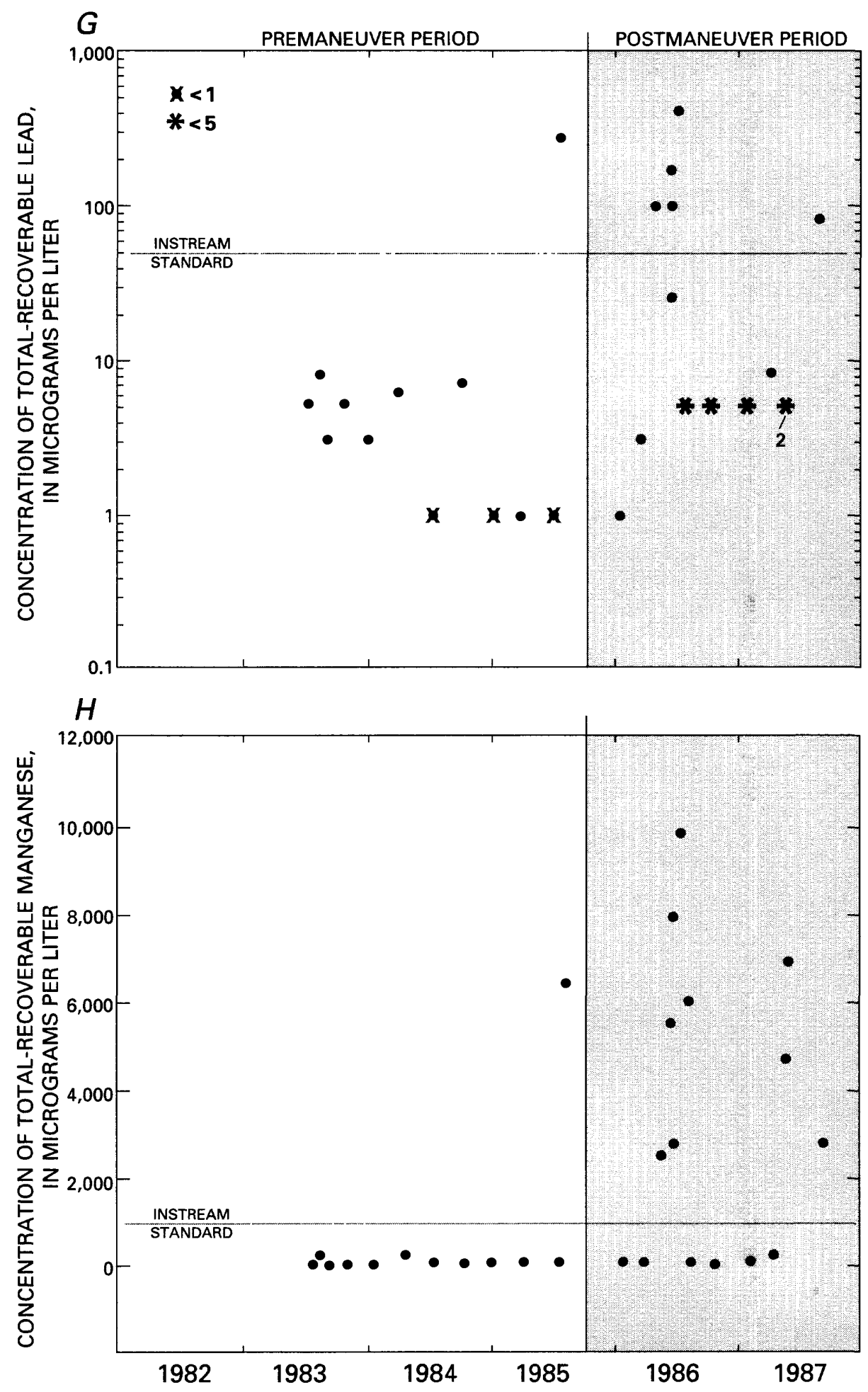

Figure 10.--Selected chemical properties and constituents and instream water-quality standards (Colorado Department of Health, 1982) for the streamflow-gaging station Purgatoire River at Rock Crossing, near Timpas (site S10), for water years 1983 through 1987: G, total-recoverable lead; and $H$, total-recoverable manganese--Continued. 

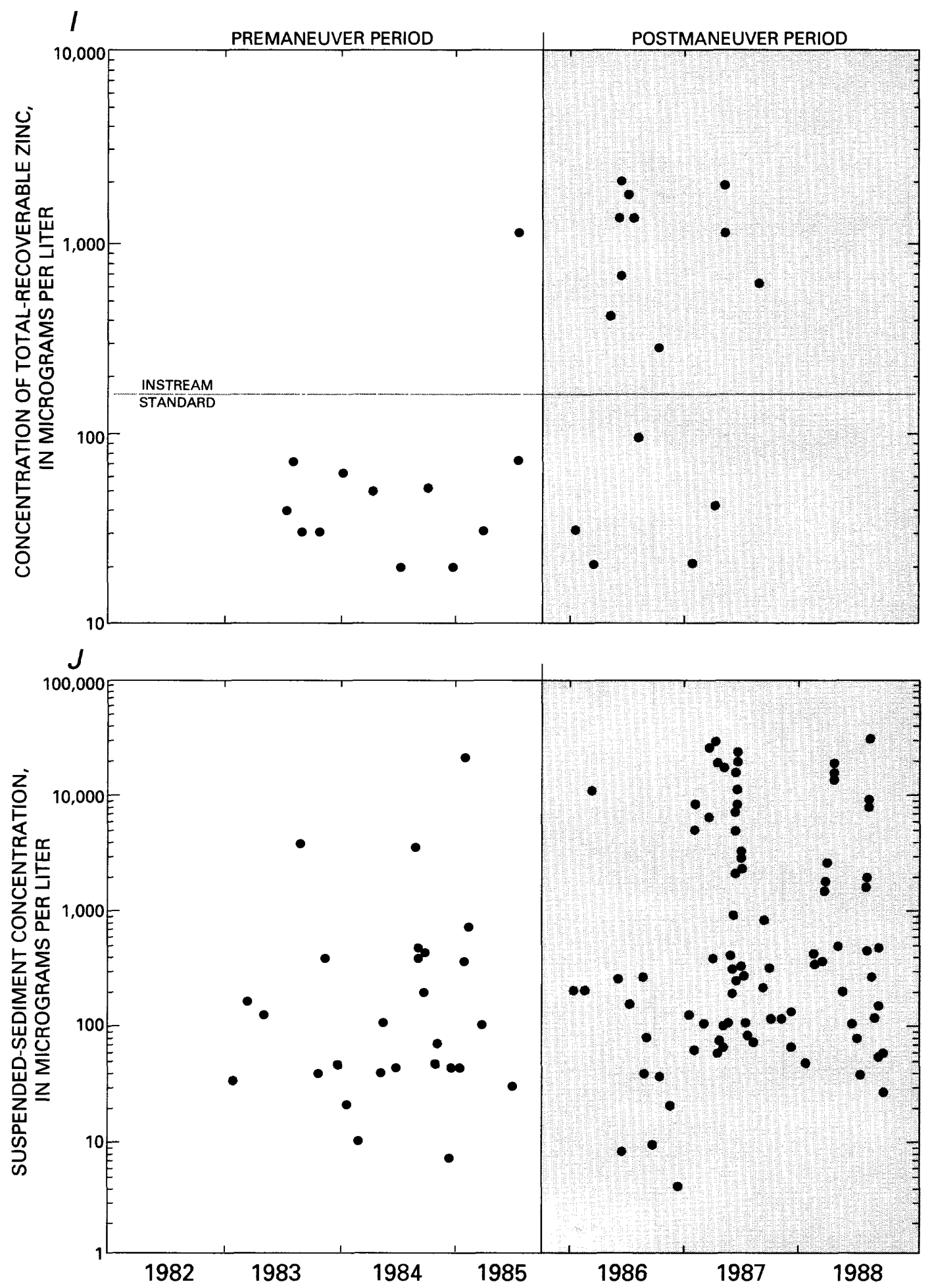

Figure 10.--Selected chemical properties and constituents and instream water-quality standards (Colorado Department of Health, 1982) for the streamflow-gaging station Purgatoire River at Rock Crossing, near Timpas (site S10), for water years 1983 through 1987: I, Total-recoverable zinc; and $J$, suspended-sediment concentration--Continued. 
Concentrations of six total-recoverable metals, dissolved chromium, and suspended sediment are shown in figures $9 \mathrm{c}-\mathrm{j}$ and $10 \mathrm{c}-\mathrm{j}$. The instream standard for total-recoverable cadmium was exceeded one time at site 54 . Instream standards were exceeded for total-recoverable copper, iron, lead, manganese, and zinc. These instream standards were exceeded during periods of streamflow that had large concentrations of suspended sediment; these periods usually are associated with snowmelt and rainfall runoff. A water-quality standard may be exceeded because of natural conditions such as flood flows or drought (Colorado Department of Health, 1982). Generally, during periods of base flow, metal concentrations were equal to or less than the instream standards. No graph of cyanide concentration is included; the instream standard for cyanide is $5.0 \mu \mathrm{g} / \mathrm{L}$, and all samples analyzed for cyanide were less than the range of detection limits $(0.01$ to $0.05 \mu \mathrm{g} / \mathrm{L})$ of the methods used for cyanide analysis.

\section{Summary Statistics and Analysis of Change Between Pre- and Postmaneuver} Periods for Selected Water-Quality Properties and Constituents

Summary statistics for selected water-quality properties and constituents at the Purgatoire River near Thatcher (site S4) and the Purgatoire River at Rock Crossing, near Timpas (site S10), for pre- and postmaneuver periods are listed in table 11. Water-quality constituents often may be related to streamflow. To test for changes between the pre- and postmaneuver periods, water-quality data need to be flow adjusted to remove the effects of streamflow (Crawford and others, 1983, p. 10). Streamflow may mask variations in water quality attributable to changes in land use or to contributions of tributary inflow from tributaries other than those draining the Maneuver Site. Flow-adjusted concentration for dissolved nitrite plus nitrate and for totalrecoverable copper, iron, lead, manganese, and zinc were determined by using the equation:

$$
\log k=a+b(\log Q)
$$

where $\mathrm{k}=$ concentration of a water-quality property or constituent;

$a=$ regression constant;

$\mathrm{b}=$ regression coefficient; and

$Q=$ instantaneous streamflow, in cubic feet per second.

Dissolved-oxygen concentrations were not flow adjusted but were adjusted by determining the ratio of dissolved-oxygen concentration to dissolvedoxygen concentration at saturation. Analysis of this ratio accounts for the effect of water temperature and barometric pressure on dissolved-oxygen concentrations.

The need for flow-adjustment of the water-quality data is illustrated in the following example. There appears to be a difference between the pre- and post-manuever periods for concentrations of some total-recoverable metals (figs. 9 and 10). For example, at site S10 the median concentrations for total-recoverable iron for the pre- and post-manueuver period are 1,035 and $100,000 \mathrm{mg}$, this increase is a result of sampling at higher streamflows during 


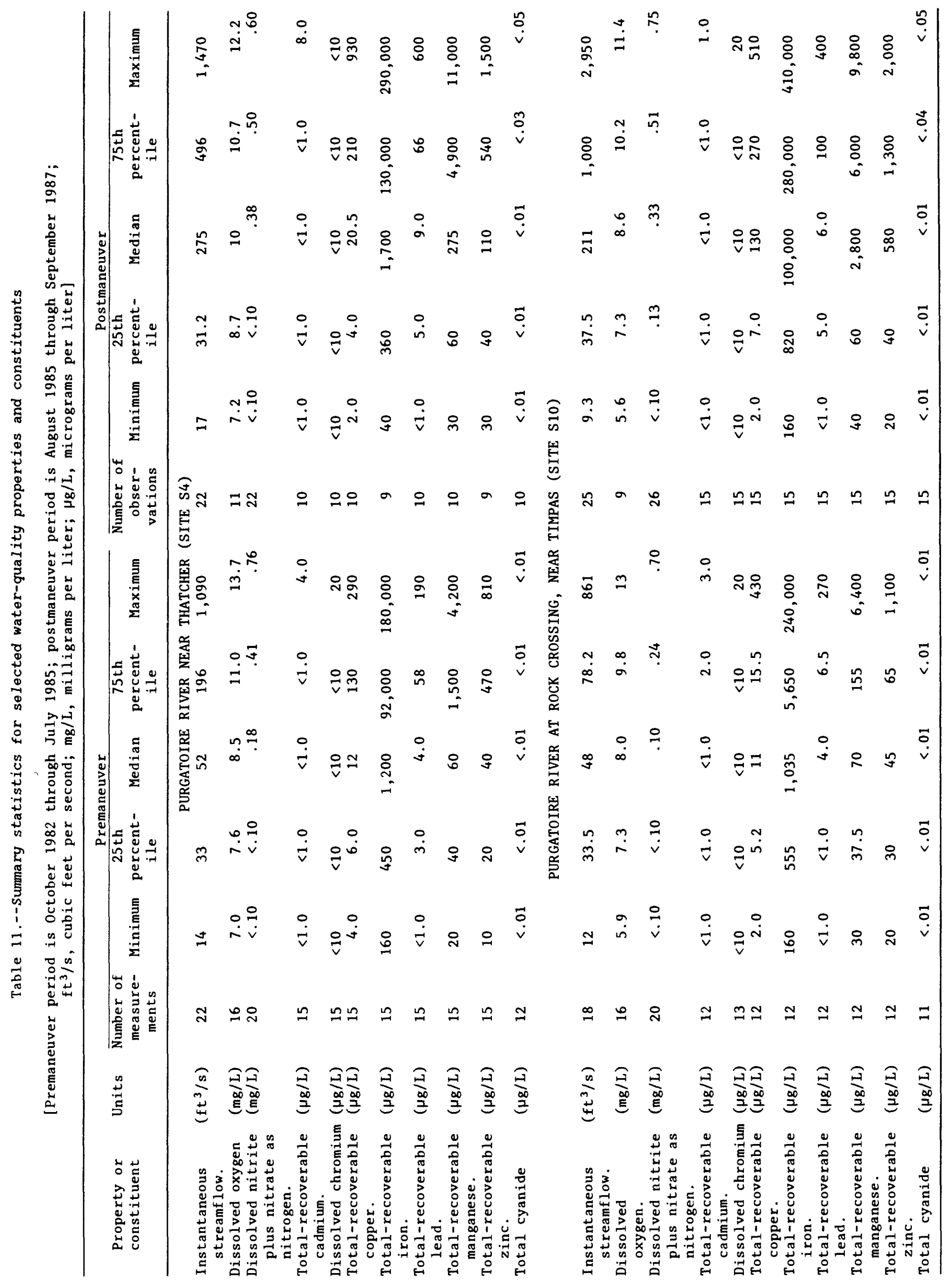


the post manuever period (table 11). When the effect of streamflow on totalrecoverable iron is removed (flow adjustment) and the flow-adjusted concentrations (residuals) are plotted versus time there is no apparent change between the pre- and post-manuever period (fig. 11). Therefore, it is important to remove the effects of streamflow prior to doing statistical trend analysis.

Once the relation between streamflow and concentration of the waterquality constituent was determined, the residual values (difference between the predicted values from the regression relations and the actual values) were calculated. These residuals were analyzed for change between the pre- and postmaneuver periods.

Dissolved oxygen and flow-adjusted concentrations for selected waterquality constituents for the Purgatoire River near Thatcher (site S4) and the Purgatoire River at Rock Crossing, near Timpas (site S10), were tested for changes between the pre- and postmaneuver periods by using the seasonal rank-sum test. Except for total-recoverable zinc at site S4, there were no significant differences $(p>0.05)$ in any of the selected water-quality constituents or in dissolved oxygen between the pre- and postmaneuver periods (table 12). No test for change in the concentrations of total-recoverable cadmium, dissolved chromium, and total cyanide was made because most of the samples analyzed had concentrations less than the detection limit of the analytical method.

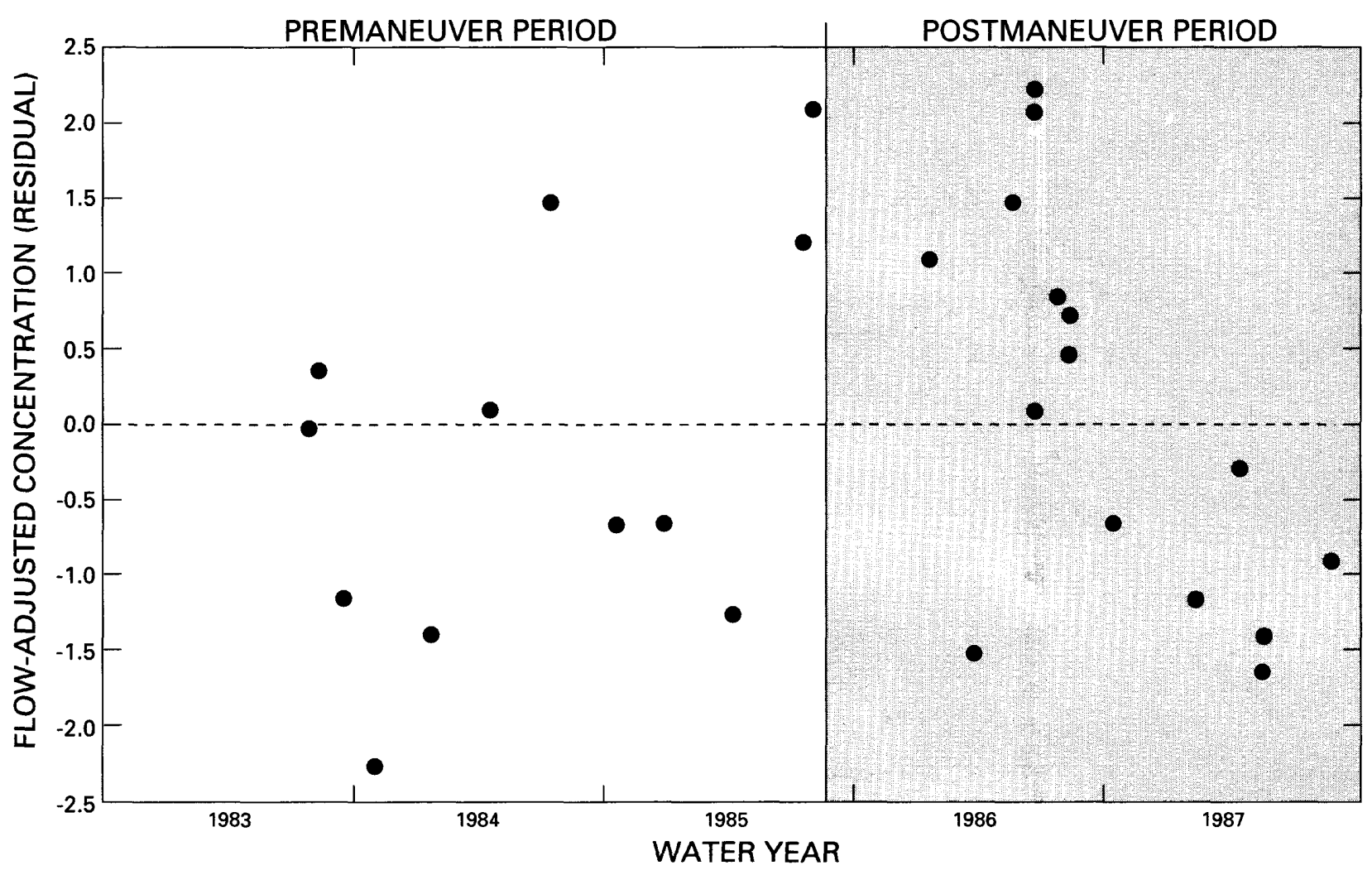

Figure 11.--Flow-adjusted concentrations of total-recoverable iron for the Purgatoire River at Rock Crossing near Timpas (site S10) for water years 1983 through 1987. 
Table 12.--overall p-values from seasonal rank-sum test for change between pre- and postmaneuver periods for a selected water-quality property or constituent

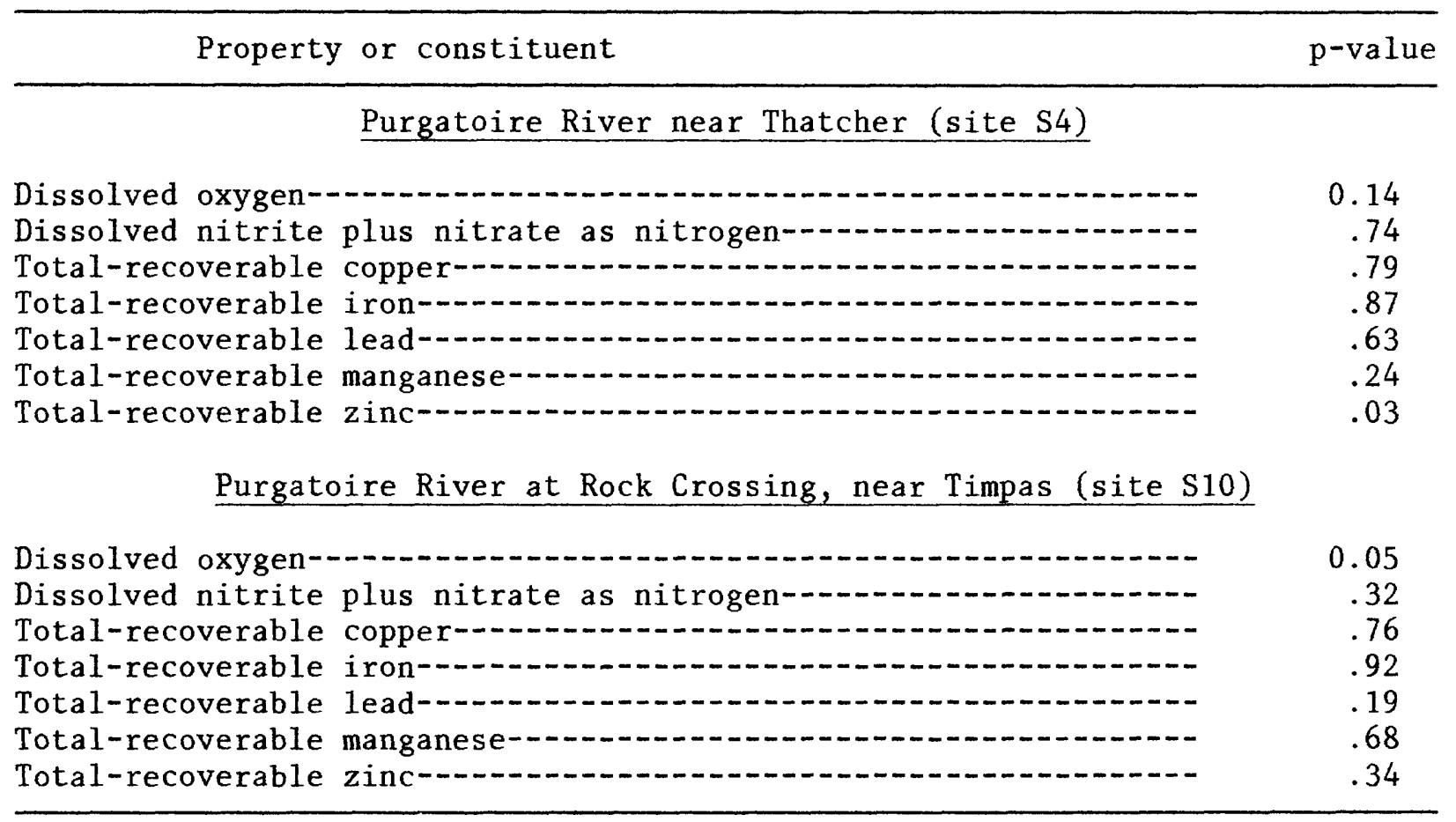

\section{Specific Conductance in the Purgatoire River}

Although no significant changes in streamflow that resulted from military maneuvers were detected at the Purgatoire River near Thatcher (site S4) (pl. 1) and the Purgatoire River below Rock Crossing, near Timpas (site S10), changes in land use at the Maneuver Site may have increased dissolved-solids concentrations in the Purgatoire River. Because soils at the Maneuver Site art slightly to moderately saline, any increase in soil erosion could result in larger quantities of soluble salts being transported by streamflow that originates on the Maneuver Site. This, in turn, would result in larger values of specific conductance because specific conductance has been shown to be correlated to dissolved-solids concentrations (von Guerard and others, 1987, p. 51). Therefore, testing for changes in specific conductance between preand postmaneuver periods could provide an indication as to whether or not dissolved solids increased in the Purgatoire River between sites S4 and S10.

Daily mean specific-conductance data for water years 1984 through 1987 are available for the Purgatoire River near Thatcher (site S4) and for the Purgatoire River at Rock Crossing, near Timpas (site S10) (p1. 1). Summary statistics of monthly mean specific conductance for pre- and postmaneuver periods at sites $\mathrm{S} 4$ and $\mathrm{S} 10$ are listed in table 13. To avoid serial correlation of the daily specific-conductance data, monthly mean specific conductance was used in the following analysis. Monthly mean specific conductance was computed for months that had sufficient data available to estimate any missing 


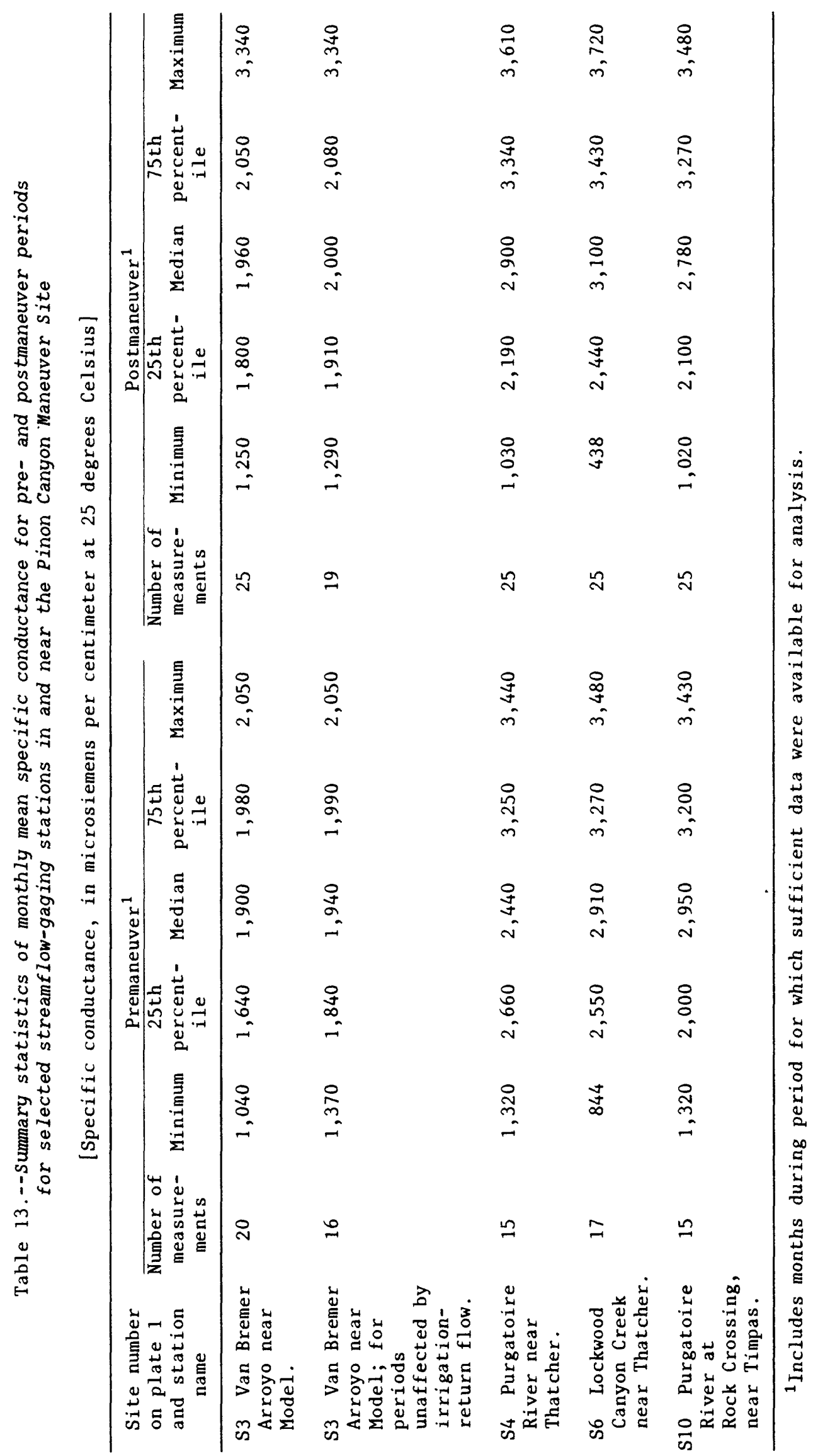


daily specific conductance. Monthly mean specific conductance was not calculated for months when data were insufficient to estimate missing records or when streamflow conditions were too variable to estimate the missing record with reasonable accuracy. Monthly mean specific-conductance data were flow adjusted at sites $\mathrm{S} 4$ and site $\mathrm{S} 10$ by using the following equation:

$$
\log M S C=a+b(\log M Q)
$$

where MSC = monthly mean specific conductance, in microsiemens per centimeter at 25 degrees Celsius;

$a=$ regression constant;

$\mathrm{b}=$ regression coefficient; and

$M Q=$ monthly mean streamflow, in cubic feet per second.

Flow-adjusted monthly mean specific conductance at sites $\mathrm{S} 4$ and $\mathrm{S} 10$ was independent at a 0.05-significance level (table 5). Flow-adjusted monthly mean specific conductance at sites $\mathrm{S} 4$ and $\mathrm{S} 10$ was tested for change between pre- and postmaneuver periods by using the seasonal rank-sum test. No significant difference $(p>0.05)$ in monthly mean specific conductance was detected at sites S4 and S10 $(p=0.07$ and $p=0.33)$. The absence of a trend in flow-adjusted specific conductance during water years 1984 through 1987 at site $\mathrm{S} 4$ corresponds with the absence of long-term trends in specific conductance at this site. Cain (1987, p. 77) analyzed 142 periodic flow-adjusted specificconductance measurements for 1969 through 1983 for site S4 and detected no significant trend in the data.

Because most of the streamflow from the Maneuver Site results from rainfall runoff, any effects of military maneuvers that cause a change in the specific conductance of the Purgatoire River, specifically at site S10, probably would be indicated during periods of rainfall runoff. Further analysis of specific-conductance data at site S10 was done for periods of rainfall runoff. Serial correlation of the daily mean specific conductance was avoided by grouping the data into rainfall-runoff periods. These groups of data were analyzed for change between pre- and postmaneuver periods. The effects of streamflow from Chacuaco Creek at mouth, near Timpas (site S8) (p1. 1), were eliminated from each rainfall-runoff period at site $\mathrm{S} 10$ by subtracting the daily mean streamflow at site $S 8$ from the daily mean streamflow at site S10. Effects of specific conductance that were from streamflow at site S8 on streamflow at site $\mathrm{S} 10$ were eliminated by computing dissolvedsolids concentrations for each period at sites S8 and S10 by using the equations :

$$
\begin{aligned}
\mathrm{DS}_{8} & =0.80\left(\mathrm{SC}_{8}\right)-53, \mathrm{R}^{2}=0.99, \mathrm{SE}=14.4, \text { and } \\
\mathrm{DS}_{10} & =0.99\left(\mathrm{SC}_{10}\right)-228, \mathrm{R}^{2}=0.99, \quad \mathrm{SE}=104,
\end{aligned}
$$

where $\mathrm{DS}_{8}=$ daily mean dissolved-solids concentration, in milligrams per liter, at site $\mathrm{S} 8$;

$\mathrm{SC}_{8}=$ daily mean specific conductance, in microsiemens per centimeter at 25 degrees Celsius, at site S8;

$\mathrm{DS}_{10}=$ daily mean dissolved-solids concentration, in milligrams per liter, at site S10;

$\mathrm{SC}_{10}=$ daily mean specific conductance, in microsiemens per centimeter at 25 degrees Celsius, at site $\mathrm{S} 10$;

$\mathrm{R}^{2}=$ coefficient of determination; and

$\mathrm{SE}=$ standard error, in milligrams per liter. 
Daily mean dissolved-solids loads at sites $\mathrm{S} 8$ and $\mathrm{S} 10$ were calculated by using the equation:

$$
\text { QDS }=\text { QW } \times \text { DS } \times 0.0027 \text {, }
$$

where QDS = dissolved-solids load, in tons per day;

$\mathrm{QW}=$ streamflow, in cubic feet per second;

DS = dissolved-solids concentration, in milligrams per liter; and $0.0027=a$ unit conversion constant.

Calculated daily mean dissolved-solids load for periods of runoff at site 88 were subtracted from calculated daily mean dissolved-solids load at site S10. Then, adjusted daily mean dissolved-solids concentrations at site $\mathrm{S} 10$ were converted into adjusted daily mean specific conductance at site S10 by using the equation:

$$
\mathrm{ASC}_{10}=247+0.997\left(\mathrm{ADS}_{10}\right), \mathrm{R}^{2}=0.99, \mathrm{SE}=105
$$

where $\mathrm{ASC}_{10}=$ adjusted daily mean specific conductance in microsiemens per centimeter at 25 degrees Celsius, at site S10;

$\operatorname{ADS}_{10}=$ adjusted daily mean dissolved-solids concentration, in milligrams per liter;

$\mathrm{R}^{2}=$ coefficient of determination; and

$\mathrm{SE}=$ standard error, in microsiemens per centimeter at 25 degrees Celsius.

To eliminate the effects of streamflow, adjusted daily mean specific conductance was flow adjusted for each rainfall-runoff period at site S10 (p1. 1). The grouped flow-adjusted daily mean specific-conductance values for rainfallrunoff periods were tested for change between pre- and postmaneuver periods by using the rank-sum test (Iman and Conover, 1983, p. 280). No significant difference $(p>0.05)$ in adjusted daily mean specific conductance was detected at site $\mathrm{S} 10$ for periods of rainfall runoff between pre- and postmaneuver periods $(p=0.63)$.

\section{Specific Conductance for Streamflow in Streams that Drain the Maneuver Site}

No significant change in streamflow was detected between pre- and postmaneuver periods for streams that drain the Maneuver Site. However, military maneuvers may have increased dissolved-solids concentrations and, thus, specific-conductance values in those streams.

Daily specific-conductance data are available for water years 1984 through 1987 for Van Bremer Arroyo near Model (site S3) and Lockwood Canyon Creek near Thatcher (site S6) (p1. 1). Attempts to eliminate the effect of streamflow (flow adjustment) from the daily mean specific-conductance data at sites S3 and S6 were unsuccessful. The regression of daily mean specific conductance compared to daily mean streamflow was not significant $(\mathrm{p}=0.03)$. Therefore, specific-conductance data that were not flow adjusted were analyzed for trend. To avoid serial correlation of the daily mean specific conductance, monthly mean specific conductance was used in this analysis. 
Summary statistics of monthly mean specific conductance at Van Bremer Arroyo near Model (site S3) and Lockwood Canyon Creek near Thatcher (site S6) (p1. 1) for the pre- and postmaneuver periods are listed in table 13. There is some dependence in monthly specific-conductance data for periods of all streamflow for the periods November through March and July through October and for periods of streamflow unaffected by irrigation-return flow at site S3 for the period November through March (table 5). Because of the dependence of some of the monthly specific conductance, the significance level, alpha $=0.05$, of the seasonal rank-sum test is approximate. The significance of the change in monthly mean specific conductance between pre- and postmaneuver periods for both streamflow conditions at site $\mathrm{S} 3$ was tested by using the seasonal ranksum test. No significant difference ( $p>0.05)$ in monthly mean specific conductance was detected at site S3 for periods including all streamflow and for periods minus irrigation return flow $(p=0.12$ and $p=0.13)$.

A test for change in monthly mean specific conductance at site $\mathrm{S} 6$ between pre- and postmaneuver periods was done by using the seasonal rank-sum test. There is some dependence in the monthly specific-conductance data at site S6 during July through October (table 5); therefore, the significance level, alpha $=0.05$, is approximate. No significant difference $(p>0.05)$ between preand postmaneuver periods was detected $(p=0.66)$.

\section{LIMITATIONS OF DATA ANALYSIS}

Natural variability in quantity and quality of streamflow in a semiarid area decreases the ability of statistical tests to detect changes in the quantity and quality of streamflow caused by changes in land use of the area. Except for streamflow during base-flow periods at Van Bremer Arroyo near Model (site S3) (pl. 1), no statistically significant change in streamflow quantity and quality was detected between the pre- and postmaneuver periods for the Purgatoire River and its tributaries in and near the Maneuver Site. However, the lack of detection of a statistically significant change may be attributable in part to the short period of record available for statistical analysis. The reliability of the statistical analysis would be greatly improved if additional years of record existed.

\section{DISSOLVED-SOLIDS AND SUSPENDED-SEDIMENT LOADS}

Military maneuvers have had no apparent effect on water quality of the Purgatoire River and of streams in and near the Maneuver Site. However, analysis of dissolved-solids and suspended-sediment loads discharged by tributaries in and near the Maneuver Site for the pre- and postmaneuver periods would be useful to describe more accurately the relative contributions of these streams to the Purgatoire River.

\section{Dissolved-Solids Loads}

Equations that related dissolved solids to specific conductance for the study area were developed by von Guerard and others (1987, p. 113). These equations were used to calculate dissolved-solids concentrations from the specific-conductance record available for each site. For sites that had 
insufficient data to develop an equation that related dissolved-solids concentrations to specific conductance, equations for sites that had similar drainage basins and streamflow characteristics were used (Hem, 1985). Dissolved-solids loads were computed by using equation 5 . Where daily mean specific-conductance data were missing, daily mean dissolved-solids loads were estimated by using periods of record at the site that bracket the missing period. Monthly dissolved-solids loads were estimated for periods of extended missing record by using the regression relation between monthly dissolvedsolids loads and monthly streamflow:

$$
\log \mathrm{MDS}=\mathrm{a}+\mathrm{b}(\log \mathrm{QM})
$$

where MDS = monthly dissolved-solids load, in tons;

$\mathrm{a}=$ regression constant;

$\mathrm{b}=$ regression coefficient; and

$\mathrm{QM}=$ monthly streamflow, in cubic feet per second.

Dissolved-solids loads for streams in and near the Maneuver Site for water year 1985 were estimated by von Guerard and others (1987) by assuming that a mean specific conductance was applicable to all streamflow-gaging stations along ephemeral streams. After 1985, site-specific values of specific conductance for water years 1984 through 1987 have become available for analysis. Dissolved-solids loads listed in table 14 include water years 1984 through 1987; data for water year 1985 that originally were published by von Guerard and others (1987, p. 53) are updated.

Table 14.--Dissolved-solids load at streamflow-gaging stations in and near Pinon Canyon Maneuver Site for water years 1984 through 1987

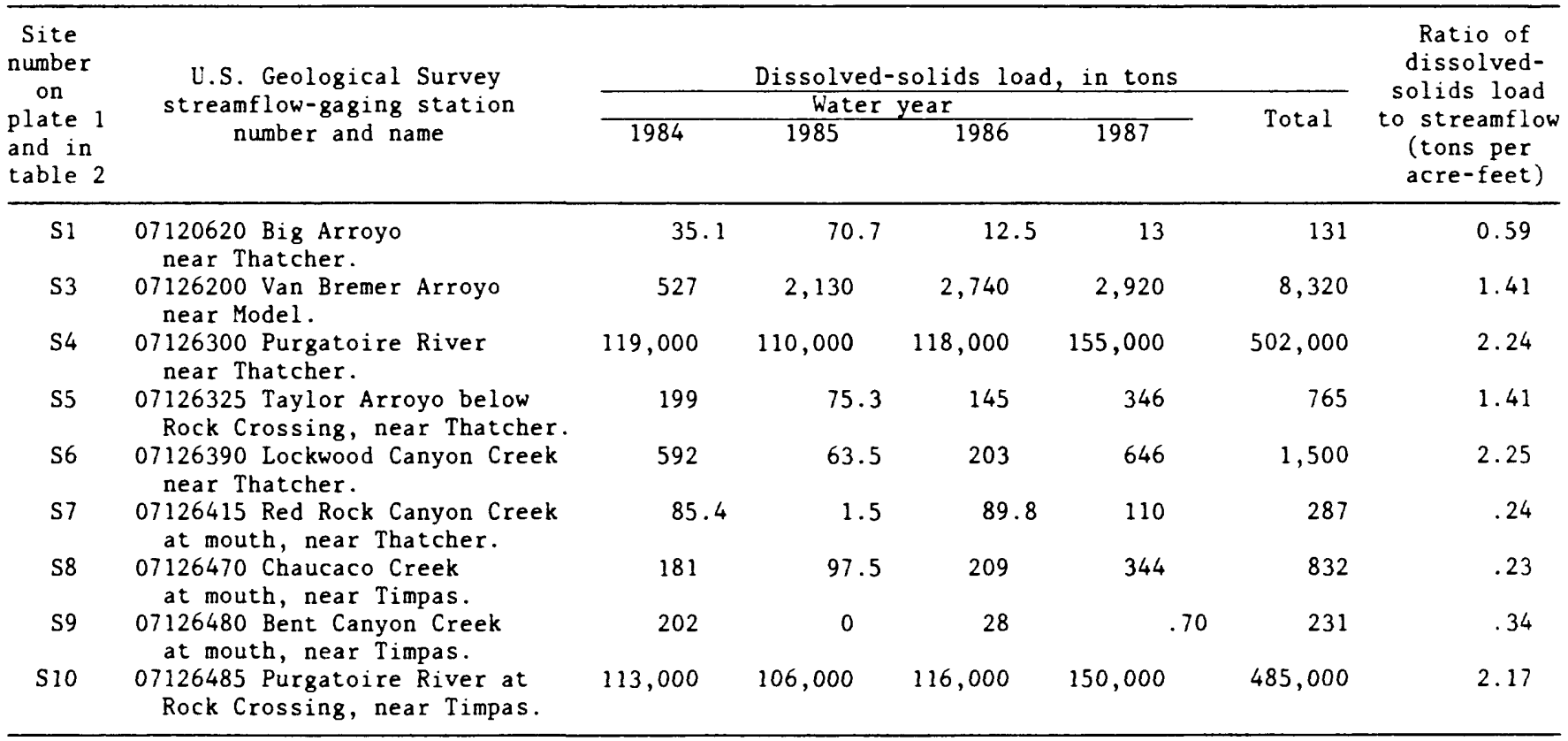


Streams that drain the Maneuver Site had annual dissolved-solids loads ranging from 0 ton for water year 1985 at Bent Canyon Creek at mouth, near Timpas (site S9), to 2,920 tons for water year 1987 at Van Bremer Arroyo near Model (site S3) (table 14). Assuming that 50 percent of gaged tributary streamflow reaches the Purgatoire River and that dissolved solids did not increase or decrease, except for site S1, the dissolved-solids load during water years 1984 through 1987 for streams that drain the Maneuver Site represented about 1.1 percent of the dissolved-solids load at site S10, of which about 75 percent was contributed by flow at site S3. For the same period, dissolved-solids load at Chacuaco Creek at mouth, near Timpas (site S8) represented 0.17 percent of the dissolved-solids load at site S10.

Analysis of the ratio of dissolved-solids load to streamflow (table 14) indicates that, generally, perennial and intermittent streams (sites S3, S4, S6, and S10) transport more tons of dissolved solids per acre-foot of streamflow than do ephemeral streams (sites S1, S5, S7, S8, and S9). During periods of low streamflow, dissolved-solids concentrations are largest. The steady supply of dissolved solids at low streamflows results in the low streamflows transporting most of the annual dissolved-solids load (von Guerard and others, 1987, p. 55). Further analysis of dissolved-solids loads indicates that 9,820 tons, or about 87 percent of the dissolved-solids load discharged from the Maneuver Site are from the intermittent streams Van Bremer Arroyo near Model (site S3) and Lockwood Canyon Creek near Thatcher (site S6) (table 14).

\section{Suspended-Sediment Loads}

Suspended-sediment loads at streamflow-gaging stations in and near the Maneuver Site for water years 1984 and 1985 were discussed in von Guerard and others (1987, p. 57). During water years 1984 through 1987, total annual suspended-sediment loads at the Purgatoire River, near Thatcher (site S4) (p1. 1) and Purgatoire River at Rock Crossing, near Timpas (site S10), were $1,870,000$ and $1,890,000$ tons (table 15). Suspended-sediment loads for water years 1986 and 1987 at sites S4 and S10 were about 1,040,000 and about 1,090,000 tons greater than suspended-sediment loads for water years 1984 through 1985. During the same period, suspended-sediment loads for Taylor Arroyo below Rock Crossing, near Thatcher (site S5), and Bent Canyon Creek at mouth, near Timpas (site S9) (p1. 1), decreased by about 14,700 tons compared with suspended-sediment loads for water years 1984 through 1985 . The source of the increased suspended-sediment loads at sites S4 and S10 most likely is from drainage areas other than those originating from the Maneuver Site.

No significant change in monthly streamflow occurred on the Purgatoire River between the pre- and postmaneuver periods. However, a large increase occurred in suspended-sediment load at sites S4 and S10 between the total of water years 1984 and 1985 and the total of water years 1986 and 1987 (table 15). Most suspended sediment is transported during periods of flooding (von Guerard and others, 1987, p. 57). Increases in suspended-sediment loads at sites S4 and S10 during water years 1986 and 1987 are a result of flood flows during certain months. For example, during water year 1986, about 70 and 69 percent of the suspended-sediment load was transported at sites $\mathrm{S} 4$ and S10 during flooding in June and August. For water year 1987, about 65 and 67 percent of the suspended-sediment load at sites S4 and S10 was transported during flooding in May. 
Table 15.--Suspended-sediment load at streamflow-gaging stations in and near Pinon Canyon Maneuver site for water years 1984 through 1987

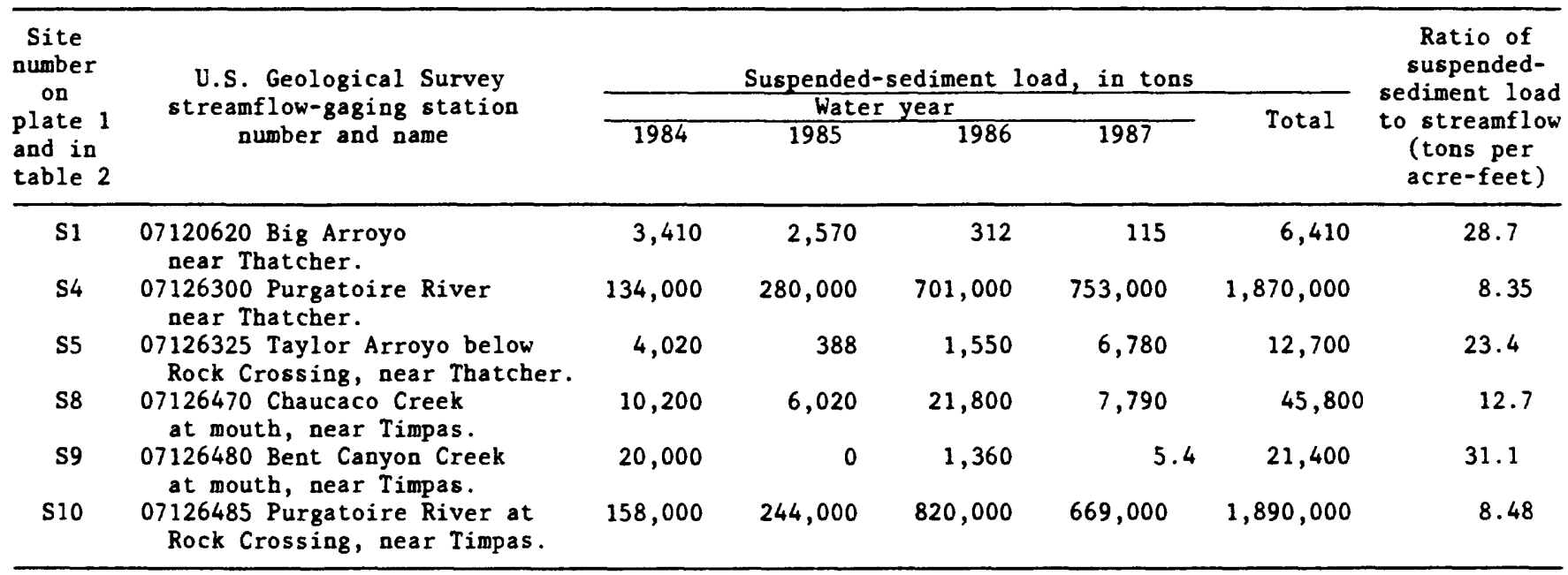

Total suspended-sediment loads for water years 1986 and 1987 were related to streamflow by computing the ratio of suspended-sediment load to streamflow. Streamflow-gaging stations. on the Purgatoire River had the smallest quantity of suspended-sediment load transported per acre-foot of streamflow--8.35 tons/ acre-ft at site S4 and 8.48 tons/acre-ft at site S10. Suspended-sediment load transported per acre-foot at tributary streams ranged from 12.7 tons/acre-ft at site $\mathrm{S} 8$ to 31.1 tons/acre-ft at site S9 (table 15).

Suspended-sediment load that was transported at sites S5 and S9 (p1. 1) for water years 1984 through 1987 was about 0.67 percent and 1.1 percent of the suspended-sediment load that was transported at the Purgatoire River at Rock Crossing, near Timpas (site S10). Suspended-sediment load during water years 1984 through 1987 at Chacuaco Creek at mouth, near Timpas (site S8), was 45,800 tons (table 15), or about 2.4 percent of the suspended-sediment load that was transported at site $\mathrm{S} 10$.

\section{EFFECTS OF MILITARY MANEUVERS ON SEDIMENT YIELDS}

The effects of military maneuvers on sediment yields were evaluated by using a qualitative method for estimating mean annual sediment yields that was developed by the Pacific Southwest Inter-Agency Committee (PSIAC) (1968). The PSIAC method considers nine factors that affect sediment yields; these are: (1) surface geology, (2) soils, (3) climate, (4) runoff, (5) topography, (6) ground cover, (7) land use, (8) upland erosion, and (9) channel erosion and sediment transport. Each factor is assigned a numerical rating based on those listed in table 16. The sum of these numerical ratings then is compared with the rating column (the last column) in table 17, which corresponds to a range of annual sediment yields in acre-feet per square mile. 
Table 16.--Factors for estimating mean annual sediment yield

[Method based on Pacific Southwest Inter-Agency Comittee (1968)]

\begin{tabular}{|c|c|c|c|c|c|c|c|c|c|}
\hline $\begin{array}{l}\text { Sedi- } \\
\text { ment } \\
\text { yield } \\
\text { levels }\end{array}$ & $\begin{array}{l}\text { Surface } \\
\text { geology }\end{array}$ & Soils & Clinate & Runoff & Topography & Ground cover & Land use & Upland erosion & $\begin{array}{l}\text { Channel } \\
\text { erosion and } \\
\text { sediment } \\
\text { transport }\end{array}$ \\
\hline $\begin{array}{l}\text { Moder- } \\
\text { ate }^{2}\end{array}$ & $\begin{array}{l}\text { (5) } \\
\text { a. Rocks of } \\
\text { medium } \\
\text { hardness. } \\
\text { b. Moder- } \\
\text { ately } \\
\text { weathered. } \\
\text { c. Moder- } \\
\text { ately } \\
\text { fractured. }\end{array}$ & $\begin{array}{l}\text { (5) } \\
\text { a. Medium tex- } \\
\text { tured soil. } \\
\text { b. Occasional } \\
\text { rock frag- } \\
\text { ments. } \\
\text { c. Caliche } \\
\text { layers. }\end{array}$ & 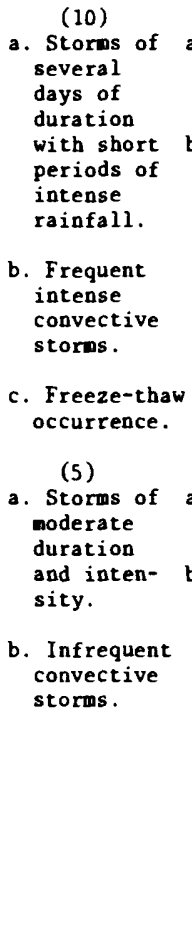 & $\begin{array}{l}\text { (10) } \\
\text { a. High peak } \\
\text { flows per } \\
\text { unit area. } \\
\text { b. Large vol- } \\
\text { ume of flow } \\
\text { per unit } \\
\text { area. }\end{array}$ & $\begin{array}{l}(10) \\
\text { a. Moderate up- } \\
\text { land slopes } \\
\text { (less than } \\
20 \text { percent). } \\
\text { b. Moderate fan } \\
\text { or flood plain } \\
\text { development. }\end{array}$ & $\begin{array}{l}(10) \\
\text { Ground cover } \\
\text { does not } \\
\text { exceed } \\
20 \text { percent. } \\
\text { a. Vegetation } \\
\text { sparse; } \\
\text { little or } \\
\text { no litter. } \\
\text { b. No rock } \\
\text { in surface } \\
\text { soil. }\end{array}$ & $\begin{array}{l}(0) \\
\text { a. Less than } \\
25 \text { percent } \\
\text { cultivated. } \\
\text { b. Fifty per- } \\
\text { cent or } \\
\text { less } \\
\text { recently } \\
\text { logged. } \\
\text { c. Less than } \\
50 \text { percent } \\
\text { intensively } \\
\text { grazed. } \\
\text { d. Ordinary } \\
\text { road and } \\
\text { other con- } \\
\text { struction. }\end{array}$ & $\begin{array}{l}\quad(10) \\
\text { a. About } \\
25 \text { percent } \\
\text { of the area } \\
\text { characterized } \\
\text { by rill and } \\
\text { gully or } \\
\text { landslide } \\
\text { erosion. } \\
\text { b. Wind erosion } \\
\text { with deposi- } \\
\text { tion in } \\
\text { stream } \\
\text { channels. }\end{array}$ & $\begin{array}{l}\text { (25) } \\
\text { a. Eroding } \\
\text { banks con- } \\
\text { tinuously } \\
\text { or at } \\
\text { frequent } \\
\text { intervals } \\
\text { with large } \\
\text { depths and } \\
\text { long flow } \\
\text { duration. } \\
\text { b. Active } \\
\text { headcuts } \\
\text { and degra- } \\
\text { dation in } \\
\text { tributary } \\
\text { channels. } \\
\text { (10) } \\
\text { a. Moderate } \\
\text { flow } \\
\text { depths, } \\
\text { medium } \\
\text { flow } \\
\text { with } \\
\text { occasion- } \\
\text { ally } \\
\text { eroding } \\
\text { banks or } \\
\text { beds. }\end{array}$ \\
\hline Low $^{2}$ & $\begin{array}{l}(0) \\
\text { a. Massive, } \\
\text { hard } \\
\text { forma- } \\
\text { tions. }\end{array}$ & $\begin{array}{l}\quad(0) \\
\text { a. High per- } \\
\text { centage of } \\
\text { rock frag- } \\
\text { ments. } \\
\text { b. Aggregated } \\
\text { clays. } \\
\text { c. High in } \\
\text { organic } \\
\text { matter. }\end{array}$ & $\begin{array}{l}(0) \\
\text { a. Humid } \\
\text { climate } \\
\text { with rain- } \\
\text { fall of low } \\
\text { intensity- } \\
\text { b. Precipi- } \\
\text { tation in } \\
\text { form of } \\
\text { snow. } \\
\text { c. Arid cli- } \\
\text { mate; low } \\
\text { intensity } \\
\text { storms. } \\
\text { d. Arid cli- } \\
\text { mate; rare } \\
\text { convective } \\
\text { storms. }\end{array}$ & $\begin{array}{l}(0) \\
\text { a. Low peak } \\
\text { flows per } \\
\text { unit area. } \\
\text { b. Low volume } \\
\text { of runoff } \\
\text { per unit } \\
\text { acre. } \\
\text { c. Rare run- } \\
\text { off events. }\end{array}$ & $\begin{array}{l}(0) \\
\text { a. Gentle up- } \\
\text { land slopes } \\
\text { (less than } \\
5 \text { percent). } \\
\text { b. Extensive } \\
\text { alluvial } \\
\text { plains. }\end{array}$ & $\begin{array}{l}(-10) \\
\text { a. Area con- } \\
\text { pletely } \\
\text { protected } \\
\text { by vegeta- } \\
\text { tion; rock } \\
\text { fragments, } \\
\text { litter; } \\
\text { little } \\
\text { opportun- } \\
\text { ity for } \\
\text { rainfall } \\
\text { to reach } \\
\text { erodible }\end{array}$ & $\begin{array}{l}(-10) \\
\text { a. No culti- } \\
\text { vation. } \\
\text { b. No recent } \\
\text { logging. } \\
\text { c. Low } \\
\text { intensity } \\
\text { grazing. }\end{array}$ & $\begin{array}{l}(0) \\
\text { a. No apparent } \\
\text { signs of } \\
\text { erosion. }\end{array}$ & $\begin{array}{l}\text { (0) } \\
\text { a. Wide } \\
\text { shallow } \\
\text { channels } \\
\text { with flat } \\
\text { gradients, } \\
\text { short flow } \\
\text { duration. } \\
\text { b. Channels } \\
\text { in massive } \\
\text { rock; } \\
\text { large } \\
\text { boulders } \\
\text { or well } \\
\text { vegetated. } \\
\text { c. Artifi- } \\
\text { cially } \\
\text { controlled } \\
\text { channels: }\end{array}$ \\
\hline
\end{tabular}

${ }^{1}$ The numbers in specific boxes indicate values to be assigned appropriate characteristics. The small letters a, b, and $c$, refer to independent characteristics to which full value may be assigned.

${ }^{2}$ If experience so indicates, interpolation between the three sediment-yield levels may be made. 
Table 17.--kating conversions used for estimating sediment yield

[Rating conversions based on Pacific Southwest Inter-Agency Committee method (1968); >, greater than]

\begin{tabular}{cc}
\hline Rating & $\begin{array}{c}\text { Sediment yield } \\
\text { acre-feet per } \\
\text { square mile })\end{array}$ \\
\hline 100 & $>3.0$ \\
$75-100$ & $1.0-3.0$ \\
$50-75$ & $0.5-1.0$ \\
$25-50$ & $0.2-0.5$ \\
$0-25$ & $0.0-0.2$ \\
\hline
\end{tabular}

Mean annual sediment yields (hereinafter referred to as sediment yields) were estimated, prior to the start of military maneuvers, for drainage basins upstream from 28 stock-watering reservoirs in and near the Maneuver Site (von Guerard and others, 1987, p. 66) and again afterward, in November 1987. Twenty-one of these drainage basins are located on the Maneuver Site and seven are located off the Maneuver Site on adjacent rangeland (pl. 1). Drainage areas of these drainage basins range in size from 0.10 to $1.2 \mathrm{mi}^{2}$ (table 18). Estimated values for the nine PSIAC factors for the premaneuver period and for November 1987 are listed in table 18. Only ground cover, land use, and upland erosion were considered to be affected by military maneuvers; hence, all other factors were the same (table 18).

The effects of military maneuvers may result in the decrease of natural vegetal cover. An effective ground cover dissipates the energy of rainfall before it strikes the soil surface, delivers water to the soil at a relatively uniform rate, and impedes the flow of water and promotes infiltration by the action of roots within the soil. Conversely, the absence of ground cover exposes the land surface to the erosive effects of rainfall and surface runoff (Pacific Southwest Inter-Agency Committee, 1968).

The factor for estimating land use does not include an appraisal for mechanized military maneuvers. Soil disturbed by turns of tracked vehicles and trails developed by multiple vehicle passes is similar to soil disturbance associated with cultivation and logging activities. In order to evaluate the changes in land use from livestock grazing to military maneuvers, the effects of military maneuvers on the land surface were considered similar to cultivation and logging activities mentioned in the PSIAC land-use rating factor (table 16). Also the residual effects of livestock grazing were considered when estimating the land-use rating for each drainage basin.

Upland erosion is indicated by rills and gullies along hillslopes and by the winnowing by eolian processes of fine material from the surface soils. Rills and gullies that develop as a result of military maneuvers would first become evident in the upland areas. Therefore, the upland erosion factor was considered one that would be sensitive in the short term to the effects of military maneuvers. 


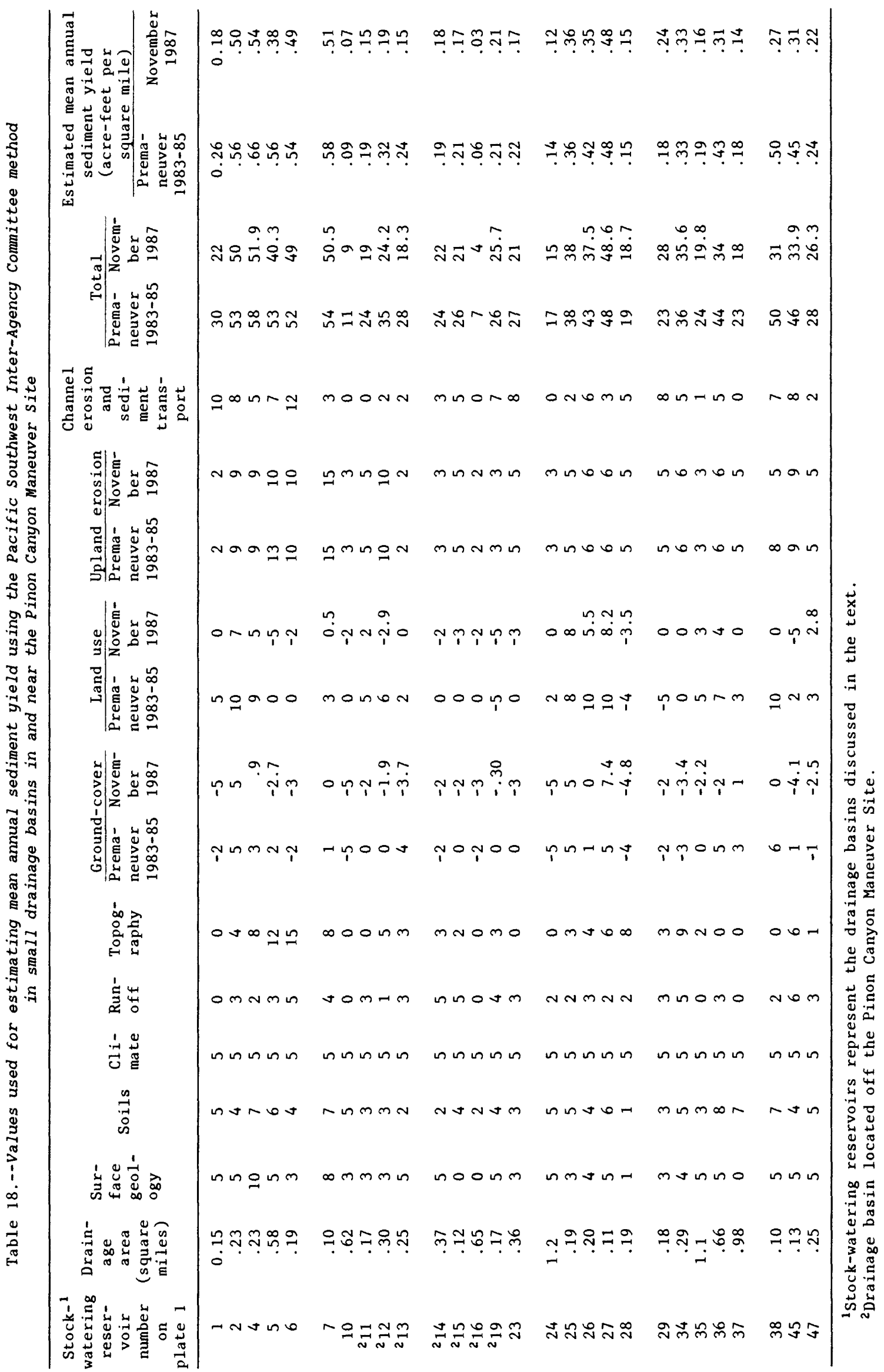


The rating factors for ground cover, land use, and upland erosion were determined for each drainage basin by visual estimation of onsite conditions (tables 16 and 18). In some drainage basins, topographic conditions were not homogeneous; where this occurred, subunits based on variations in topography were delineated. Rating factors for these drainage basins were determined by summing the area-weighted rating factors of each subunit.

\section{Sediment-Yield Estimates on the Maneuver Site}

During November 1987, sediment yields were estimated for the drainage basins above 21 stock-watering reservoirs on the Maneuver Site (p1. 1). Estimated sediment yields for 1987, when compared to premaneuver estimates, were larger for 1 drainage basin, smaller for 16 drainage basins, and relatively unchanged for 4 drainage basins (fig. 12; table 18).

Increased ground cover that resulted from normal or more than normal precipitation and changes in the intensity and patterns of land use caused a variation in estimated sediment yields from premaneuver estimates to those made November 1987. In the drainage basin where 1987 estimated sediment yield increased (number 29, table 18), the increase in the land-use factor reflected the effects of military maneuvers. In drainage basins where 1987 sediment yields decreased or were unchanged, damage from military maneuvers was nonexistent, causing a decrease (improvement) in the land-use factor, or was offset by the effects of improved ground cover.

The elimination of livestock grazing and adequate precipitation for water years 1986 and 1987 improved ground cover in untracked areas of the Maneuver Site. In 1985, total bare ground in untracked areas averaged about 64 percent prior to any military maneuvers; this decreased to about 55 percent in 1986 and to about 53 percent in 1987 (R.S. Shaw, written commun., 1987).

Litter cover increased substantially from 1985 to 1986 and in 1987. Litter accounted for 13 percent of ground cover in 1985, about 32 percent in 1986, and about 38 percent in 1987. Increased litter accumulation may be a result of variable moisture conditions between the sample periods and of the lack of grazing and the subsequent accumulation of litter. Total bare ground in tracked areas increased in 1986 about 5 percent and in 1987 about 16 percent (R.S. Shaw, written commun., 1987). Ground-cover ratings for the 21 drainage basins on the Maneuver Site decreased in 15 drainage basins, remained unchanged in 5 drainage basins, and increased in 1 drainage basin (table 18). During the hiatus between the cessation of livestock grazing and the start of military maneuvers at the Maneuver Site, land use was limited to road construction, environmental studies, and wildlife activity. The pattern and type of land use changed substantially in July 1985 when military maneuvers started. Although military maneuvers are an intensive land use, the value of the land-use factor for the 21 drainage basins on the Maneuver Site that had sediment-yield estimates decreased in 17 drainage basins, remained the same in 2 drainage basins, and increased in 2 drainage basins (table 18). Although upland erosion is a factor that may be affected by military maneuvers, the rating for upland erosion remained unchanged in 19 drainage basins and decreased in 2 drainage basins. 

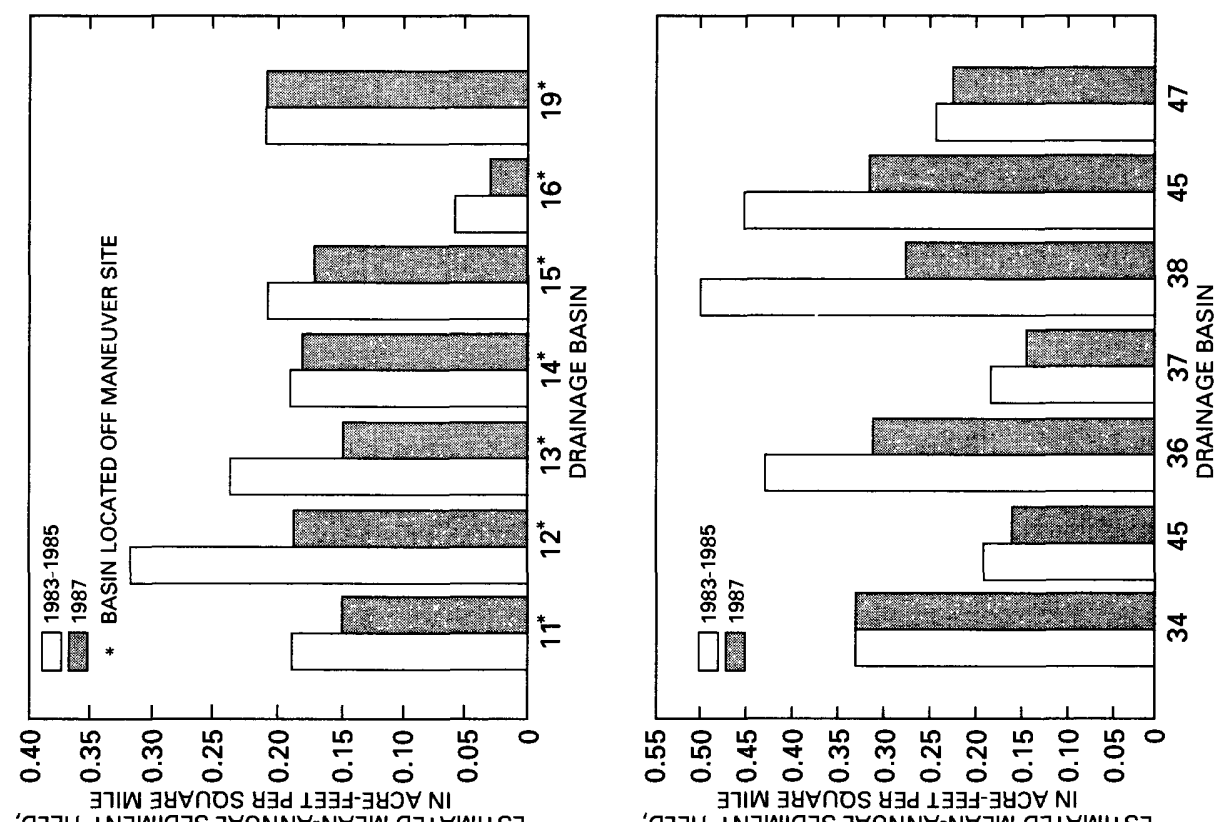

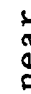

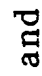

.

告

is

กั

o

(ึ)

.

艺

걱등

葛

븡

4

n

o.

20

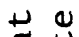

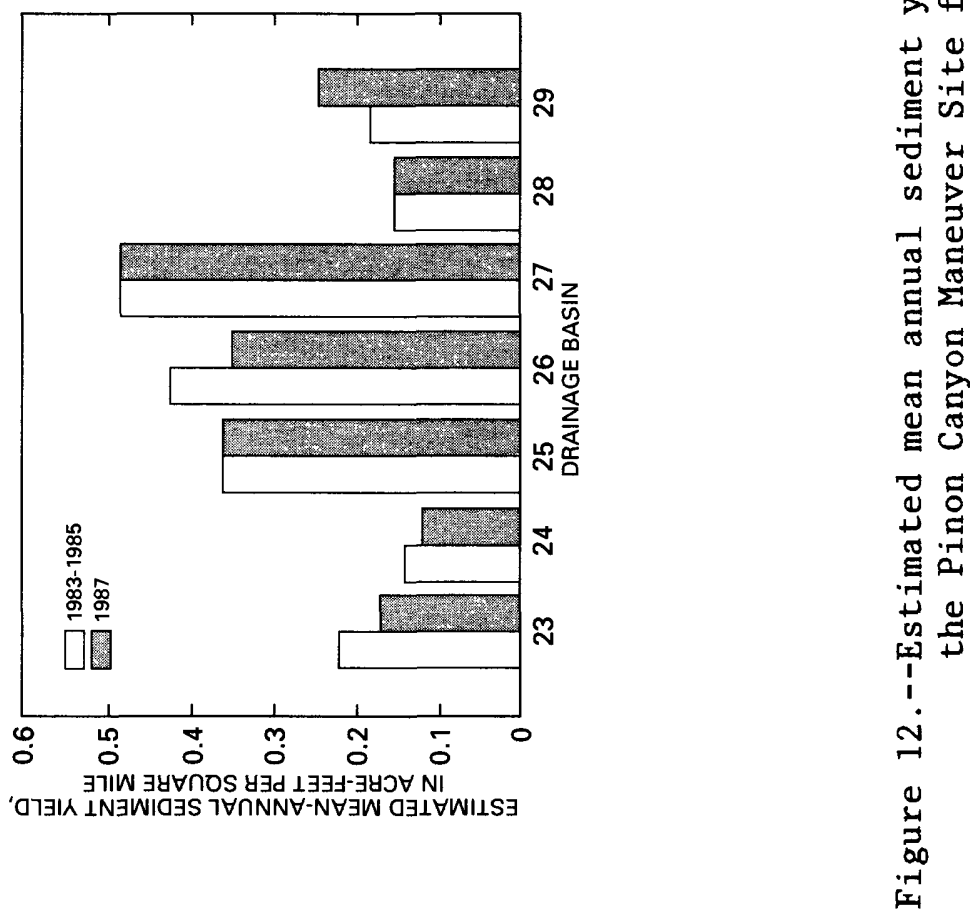


Generally, sediment yields tended to decrease for the drainage basins on the Maneuver Site. During 1983 through 1987, improvement in ground cover and the reduction in the intensity of land use tended to offset and lessen the effects of military maneuvers on estimated sediment yields.

\section{Sediment-Yield Estimates From Areas Unaffected by Military Maneuvers}

During November 1987, sediment yields were estimated for drainage basins above seven stock-watering reservoirs located off the Maneuver Site (pl. 1). Estimated sediment yields for November 1987, when compared to estimates for water years 1983 through 1985, decreased in six drainage basins and were unchanged in one (fig. 12; table 18). Generally, ground-cover and land-use ratings decreased (improved) in the seven offsite drainage basins for the November 1987 estimates. The improvement in these rating factors may be a result of adequate precipitation for water years 1986 and 1987.

The decreasing trend in estimated sediment yields is similar to that represented by the estimated sediment yields for the drainage basins on the Maneuver Site. Because these data are qualitative and are subject to the bias of the estimator, the decreasing trend is not considered significant. However, the trend does indicate the relative improvement in ground-cover and land-use conditions for the area in and near the Maneuver Site.

\section{DRAINAGE-BASIN MODELING}

The infrequent occurrence of rainfall runoff in the semiarid environment limits the quantity of data that are available for the assessment of the effects of military maneuvers on the surface water of the Maneuver Site. The application of a drainage-basin model would provide land managers with a useful tool for delineating areas where effects on the surface water of the Maneuver Site have occurred and for the evaluation of the effects of the spatial distribution of military maneuvers on the surface water. The following is a discussion of the application of the Precipitation-Runoff Modeling System (PRMS) (Leavesly and others, 1983) to the Taylor Arroyo drainage basin during water year 1987. Included in this discussion is a method for evaluating the effects of military maneuvers on the surface-water hydrology. A single storm is used in the explanation of this method. Although the use of a single storm does not allow for the evaluation of the effects of military maneuvers on the basin hydrology, the method may provide the needed analytic framework as more data become available. 


\section{Precipitation-Runoff Modeling System (PRMS)}

PRMS is a modular-design modeling system that has been developed to eva1uate the effects of various combinations of precipitation, climate, and land use on surface-water runoff and general drainage-basin hydrology (Leavesley and others, 1983) (fig. 13). Drainage-basin response to normal and extreme rainfall and snowmelt can be simulated for various combinations of land use to evaluate changes in water-balance relations, flow regimes, flood peaks and volumes, soil-water relations, and ground-water recharge. PRMS is designed to function as a lumped- or a distributed-parameter-type model and will simulate daily mean streamflows and streamflow hydrographs. PRMS is a deterministic physical-process modeling system. To reproduce the physical reality of the hydrologic system as closely as possible, each component of the hydrologic cycle is expressed in the form of known physical laws or in empirical relations that have some physical interpretation based on measurable drainagebasin characteristics (fig. 13).

PRMS components are designed using the concept of partitioning a drainage basin into hydrologic-response units (HRU's) on the basis of characteristics such as slope, aspect, vegetation type, soil type, and precipitation distribution. Partitioning provides the ability to impose land-use or climatic changes on parts or all of a drainage basin and to evaluate resulting hydrologic effects on each HRU and on the total drainage basin (Leavesley and others, 1983). A water balance and an energy balance are computed daily for each HRU. The sum of the responses of all HRU's weighted on a unit-area basis produces the daily system response and streamflow from the drainage basin.

PRMS model parameters and definitions that are used in PRMS are listed in table 19. PRMS uses a contributing-area concept to compute surface runoff (Dickinson and Whiteley, 1970; Hewlett and Nutter, 1970). The percentage of a HRU that contributes to surface runoff is computed as a nonlinear function of antecedent soil moisture and rainfall. SMAX, the maximum available waterholding capacity of the soil profile; SC1, the slope coefficient in the relation between contributing drainage area; the function of available water in the soil zone; and daily net precipitation are important in this relation. SCX, the maximum value of the contributing drainage area, for each HRU also is important. A detailed description of the model and its operation is given in Leavesley and others (1983). 


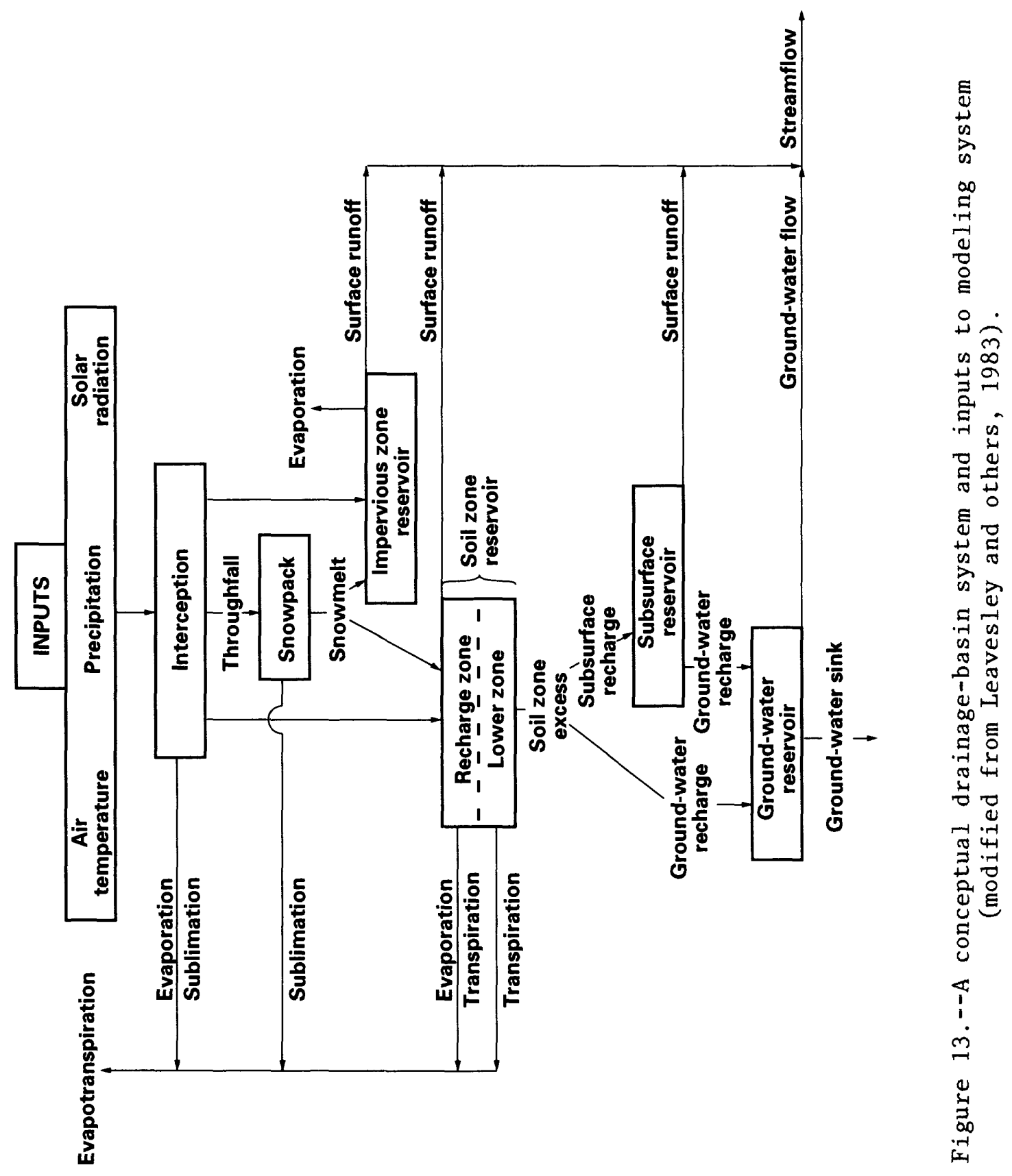


Table 19.--Selected model parameters and definitions

[Based on categories from L.G. Stannard and J.J. Vacarro (U.S. Geological Survey, written commun., 1985) and parameter listings from Leavesley and others, 1983]

\footnotetext{
Parameter Definition

CATEGORY 1--NONDISTRIBUTED PARAMETER VALUES THAT ARE DETERMINED

MAINLY FROM REGIONAL CLIMATIC CHARACTERISTICS AND THAT

APPLY TO AN ENTIRE DRAINAGE BASIN OR REGION

BST - Base air temperature above which precipitation is considered rain and below which precipitation is considered all snow.

CTS - Air temperature - evapotranspiration coefficient for use in JensenHaise equation.

CTW - Proportion of potential evapotranspiration that may be sublimated from a snow surface.

DENI - Initial density of new-fallen snow.

DENMX - Average maximum snowpack density.

EAIR - Emissivity of air on days without precipitation.

FWCAP - Free water-holding capacity of snowpack.

MRDC - Switch to determine method used to compute solar radiation for missing days ( 0 =radiation data not used; $1=$ degree - day; $2=$ sky cover).

PAT - Maximum air temperature that, when it is exceeded, causes spring and summer precipitation to be rain.

RDC - Y - Interception for relation between temperature (X) and (1) degree day (Y) or (2) sky cover (Y) when MRDC = 1 or 2 .

RDM - Slope for relation between temperature (X) and (1) degree day (Y) or (2) sky cover $(Y)$ when MRDC $=1$ or 2 .

SETCON - Snowpack-settlement time constant.
}

CATEGORY 2--PARAMETERS NONDISTRIBUTED BY SUBSURFACE OR GROUND-WATER RESERVOIRS

TLX/TLN - Lapse rate for maximum/minimum daily air temperature.

TST - Temperature index to determine beginning date of transpiration.

RES - Storage in each subsurface reservoir (acre-inches)

RESMX, REXP - Coefficients for routing water from each subsurface reservoir to a ground-water reservoir. 
Table 19.--Selected model parameters and definitions--Continued

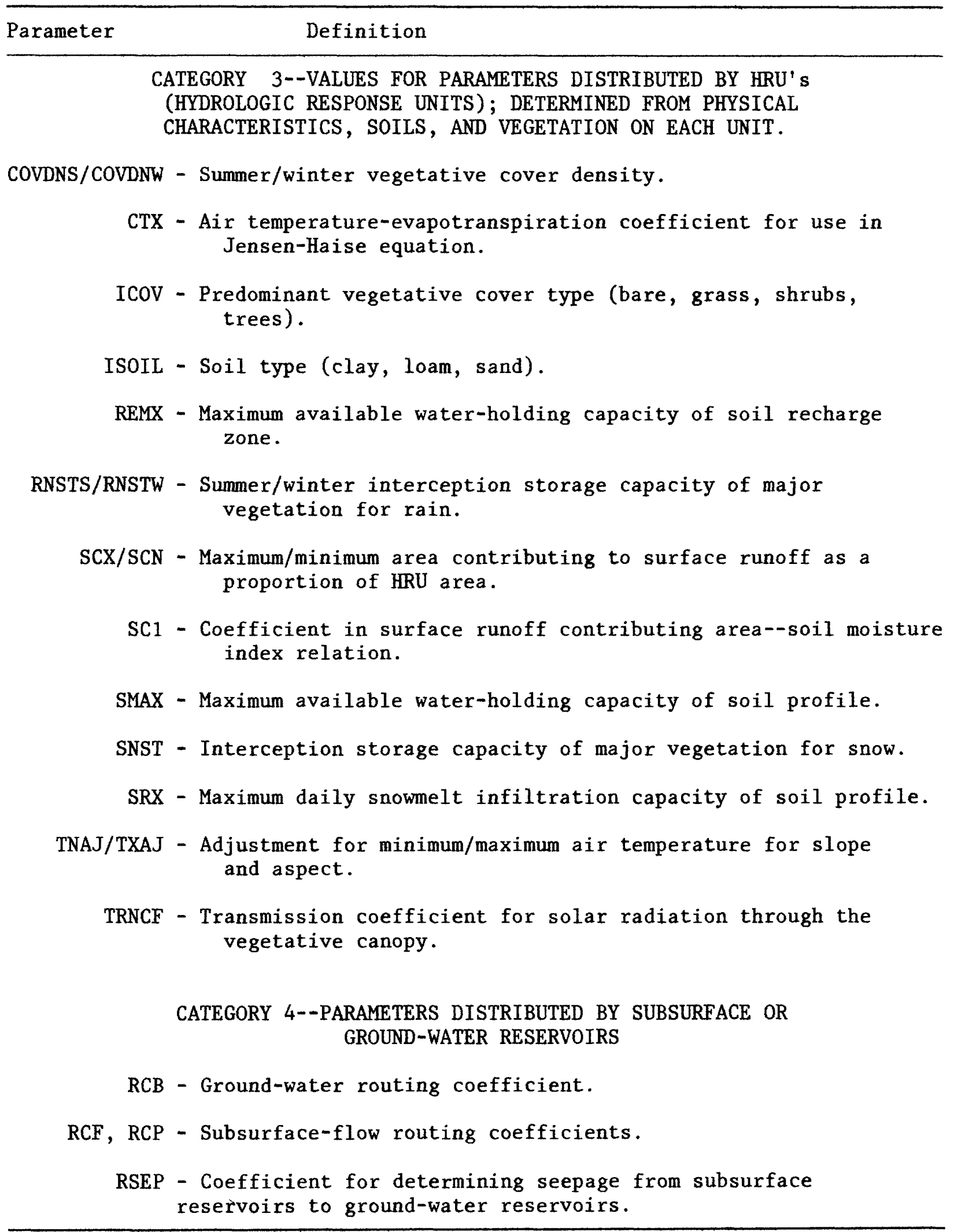




\section{Taylor Arroyo Drainage Basin}

The Taylor Arroyo drainage basin is in the western part of the Maneuver Site (fig. 2) and has an area of $48.4 \mathrm{mi}^{2}$. Taylor Arroyo originates in the Big Arroyo Hills and drains southeastward through an alluvial plain until it meets the canyon rim of the Purgatoire River. At this point, Taylor Arroyo becomes entrenched and is a side canyon to the Purgatoire River. Elevation in the drainage basin ranges from 5,905 ft in the Big Arroyo Hills in the northwestern part of the drainage basin to 4,982 $\mathrm{ft}$ at the streamflow-gaging station Taylor Arroyo below Rock Crossing, near Thatcher (site S5) (pl. 1). Soils in the drainage basin are silt loam-loam and silt clay loam-silt loam; are moderately to well drained; and have depths that range from 5 to 60 in. (U.S. Soil Conservation Service, 1983). PRMS was applied to the part of the Taylor Arroyo drainage basin upstream from site S5.

Table 20.--Summary of information for hydrologic response units for the Taylor Arroyo drainage basin

\begin{tabular}{|c|c|c|c|c|c|c|}
\hline \multirow{3}{*}{$\begin{array}{l}\text { Hydro- } \\
\text { logic } \\
\text { response } \\
\text { unit } \\
\text { number } \\
\text { (fig. 14) }\end{array}$} & \multirow{3}{*}{$\begin{array}{c}\text { Area } \\
\text { (acres) }\end{array}$} & \multirow{3}{*}{$\begin{array}{l}\text { Vegetation } \\
\text { type }\end{array}$} & \multirow{3}{*}{$\frac{\text { Soils }}{1}$} & \multicolumn{3}{|c|}{ Precipitation gages } \\
\hline & & & & Num- & & \\
\hline & & & & $\begin{array}{l}\text { Der } \\
\text { (fig }\end{array}$ & Latitude & Longitude \\
\hline 1 & 1,260 & Pinon-juniper & $\begin{array}{c}\text { Penrose-Manzanola- } \\
\text { Midway }\end{array}$ & 1 & $37^{\circ} 29^{\prime} 15^{\prime \prime}$ & $104^{\circ} 05^{\prime} 10^{\prime \prime}$ \\
\hline 2 & 1,780 & Pinon-juniper & $\begin{array}{c}\text { Penrose-Manzanola- } \\
\text { Midway }\end{array}$ & 2 & $37^{\circ} 29^{\prime} 50^{\prime \prime}$ & $104^{\circ} 02^{\prime} 10^{\prime \prime}$ \\
\hline 3 & 4,090 & Grass & $\begin{array}{c}\text { Penrose-Manzanola- } \\
\text { Midway }\end{array}$ & 3 & $37^{\circ} 29^{\prime} 33^{\prime \prime}$ & $104^{\circ} 00^{\prime} 19^{\prime \prime}$ \\
\hline 4 & 3,940 & Grass & $\begin{array}{c}\text { Penrose-Manzanola- } \\
\text { Midway }\end{array}$ & 4 & $37^{\circ} 27^{\prime} 36^{\prime \prime}$ & $104^{\circ} 04^{\prime} 43^{\prime \prime}$ \\
\hline 5 & 2,790 & Grass & $\begin{array}{c}\text { Penrose-Manzanola- } \\
\text { Midway }\end{array}$ & 5 & $37^{\circ} 28^{\prime} 31^{\prime \prime}$ & $104^{\circ} 01^{\prime} 40^{\prime \prime}$ \\
\hline 6 & 7,370 & Grass & $\begin{array}{c}\text { Penrose-Manzanola- } \\
\text { Midway }\end{array}$ & 6 & $37^{\circ} 27^{\prime} 25^{\prime \prime}$ & $103^{\circ} 59^{\prime} 40^{\prime \prime}$ \\
\hline 7 & 3,200 & Grass & $\begin{array}{l}\text { Penrose-Manzanola- } \\
\text { Midway-Travessilla- } \\
\text { Wiley-Villagreen }\end{array}$ & 7 & $37^{\circ} 26^{\prime} 19^{\prime \prime}$ & $104^{\circ} 02^{\prime} 15^{\prime \prime}$ \\
\hline 8 & 2,140 & Grass & $\begin{array}{l}\text { Penrose-Manzanola- } \\
\text { Midway-Travessilla- } \\
\text { Wiley-Villagreen }\end{array}$ & 8 & $37^{\circ} 24^{\prime} 18^{\prime \prime}$ & $104^{\circ} 00^{\prime} 16^{\prime \prime}$ \\
\hline 9 & 4,600 & Grass & $\begin{array}{l}\text { Travessilla-Wiley- } \\
\text { Villagreen-Penrose- } \\
\text { Manzanola-Midway }\end{array}$ & 9 & $37^{\circ} 24^{\prime} 59^{\prime \prime}$ & $103^{\circ} 58^{\prime} 40^{\prime \prime}$ \\
\hline
\end{tabular}

${ }^{1}$ Soils data from U.S. Soil Conservation Service (1983). 


\section{Data Collection and Drainage-Basin Segmentation}

Daily and unit streamflow and precipitation data are necessary to operate PRMS. Unit data represent time periods that are less than daily--usually minutes. Continuous streamflow data are collected for the Taylor Arroyo drainage basin at Taylor Arroyo below Rock Crossing, near Thatcher (site S5) (p1. 1). Daily precipitation data are available for water year 1987 at the Taylor Arroyo precipitation gage (site R4, p1. 1). Precipitation data are available for July through September 1987 at 5-minute intervals at a network of nine precipitation gages (table 20; fig. 2), Soil classifications were determined, and available water-holding capacity of soils was calculated by using recent soil-survey data (U.S. Soil Conservation Service, 1983). Potential evapotranspiration was estimated by PRMS by using maximum and minimum daily air-temperature data from the Las Animas County Airport.

The Taylor Arroyo drainage basin is segmented into nine HRU's (fig. 14). Initial HRU boundaries were determined by using lines equidistant from adjacent precipitation gages (Theissen polygons). These boundaries then were modified to maintain the integrity of internal subbasins. Thus, each HRU has an associated recording precipitation gage (table 20).

\section{Calibration of Precipitation-Runoff Modeling System in the Daily Mode}

PRMS was optimized by using the Rosenbrock technique (Rosenbrock, 1960). The objective function used was the sum of squares of the difference between measured and simulated daily mean streamflow. Because the rainfall-runoff process is important in the Taylor Arroyo drainage basin, the three parameters SMAX, SC1, and SCX (table 19) were used to optimize the model. The optimized values of these three parameters and values for other selected parameters are listed in table 21 .

The measured and simulated annual volume of runoff from the drainage basin compare well. The annual volume of measured runoff for water year 1987 was $0.10 \mathrm{in}$. The simulated volume of runoff was $0.11 \mathrm{in.}$ (table 22).

The water balance for water year 1987 can be defined for the simulated components in the basin (table 22). Net annual precipitation for the Taylor Arroyo drainage basin was $16.54 \mathrm{in}$. for water year 1987 . This net value excludes losses from interception. Of this net annual precipitation, about 96.4 percent was removed from the drainage basin by evapotranspiration and about 0.6 percent was removed as streamflow. These percentages indicate the importance of evapotranspiration within the drainage basin.

Annual soil-moisture storage is indicated in the water balance by subtracting the soil moisture available on the last day of the water year (September 30) from the soil moisture available on the first day of that same water year (October 1). This value of annual soil-moisture storage is affected by the initial values of soil moisture inserted in the model. Additional years of data could define the estimates of initial conditions of soil moisture and refine the value of annual soil-moisture storage. 


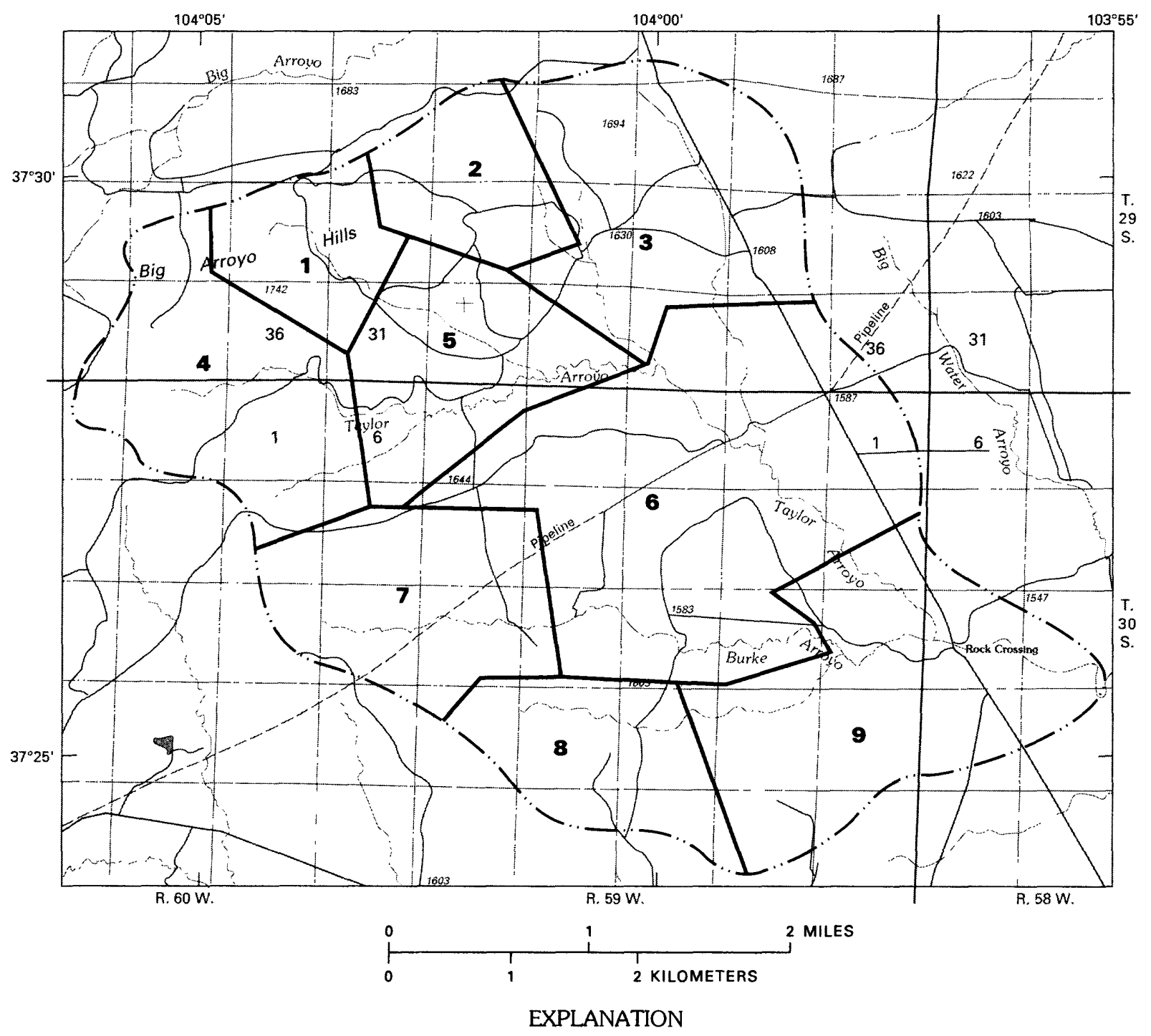

BOUNDARY OF HYDROLOGIC
RESPONSE UNIT
$-\cdots$ - DRAINAGE BASIN BOUNDARY

8 HYDROLOGIC RESPONSE UNIT NUMBER

Figure 14.--Locations of hydrologic response units in the Taylor Arroyo drainage basin. 


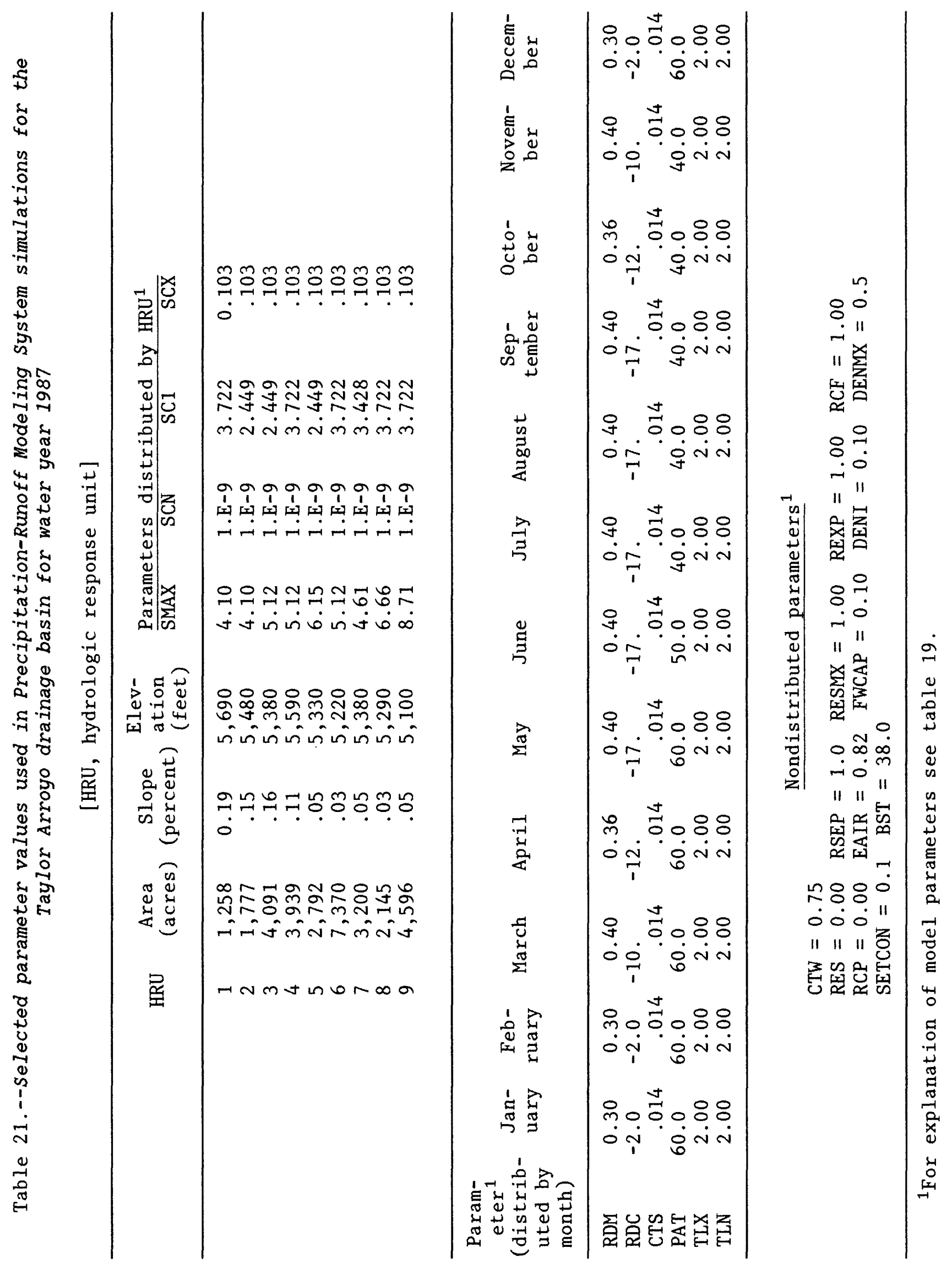


Table 22.--Water balance from Precipitation-Runoff Modeling System simulations for the Taylor Arroyo drainage basin for water year 1987

\begin{tabular}{|c|c|c|c|c|c|c|}
\hline \multirow{2}{*}{$\begin{array}{l}\text { Net } \\
\text { precip- } \\
\text { itation } \\
\text { (inches) }\end{array}$} & \multicolumn{2}{|c|}{ Evapotranspiration } & \multicolumn{2}{|c|}{ Soil moisture } & \multicolumn{2}{|c|}{ Streamflow } \\
\hline & (inches) & $\begin{array}{l}\text { (percent of } \\
\text { net precip- } \\
\text { tation) }\end{array}$ & (inches) & $\begin{array}{l}\text { (percent of } \\
\text { net precip- } \\
\text { itation) }\end{array}$ & (inches) & $\begin{array}{l}\text { (percent of } \\
\text { net precip- } \\
\text { itation) }\end{array}$ \\
\hline 16.54 & 15.94 & 96.4 & 0.49 & 3.0 & 0.11 & 0.6 \\
\hline
\end{tabular}

Analysis of the soil moisture for water year 1987 (fig. 15) indicates changes in the effect of evapotranspiration. Transpiration generally ceases in November and does not start again until April. Losses to soil moisture during the winter months primarily occur from evaporation near the soil surface. Transpiration begins again in April, and the rate of soil-moisture loss increases toward the end of the month. The cycle of recharge of soil moisture by rainfall and depletion of the soil moisture by evapotranspiration is evident from May through October. This cycle of recharge and depletion indicates the importance of the soil moisture in simulating streamflow from individual storms.

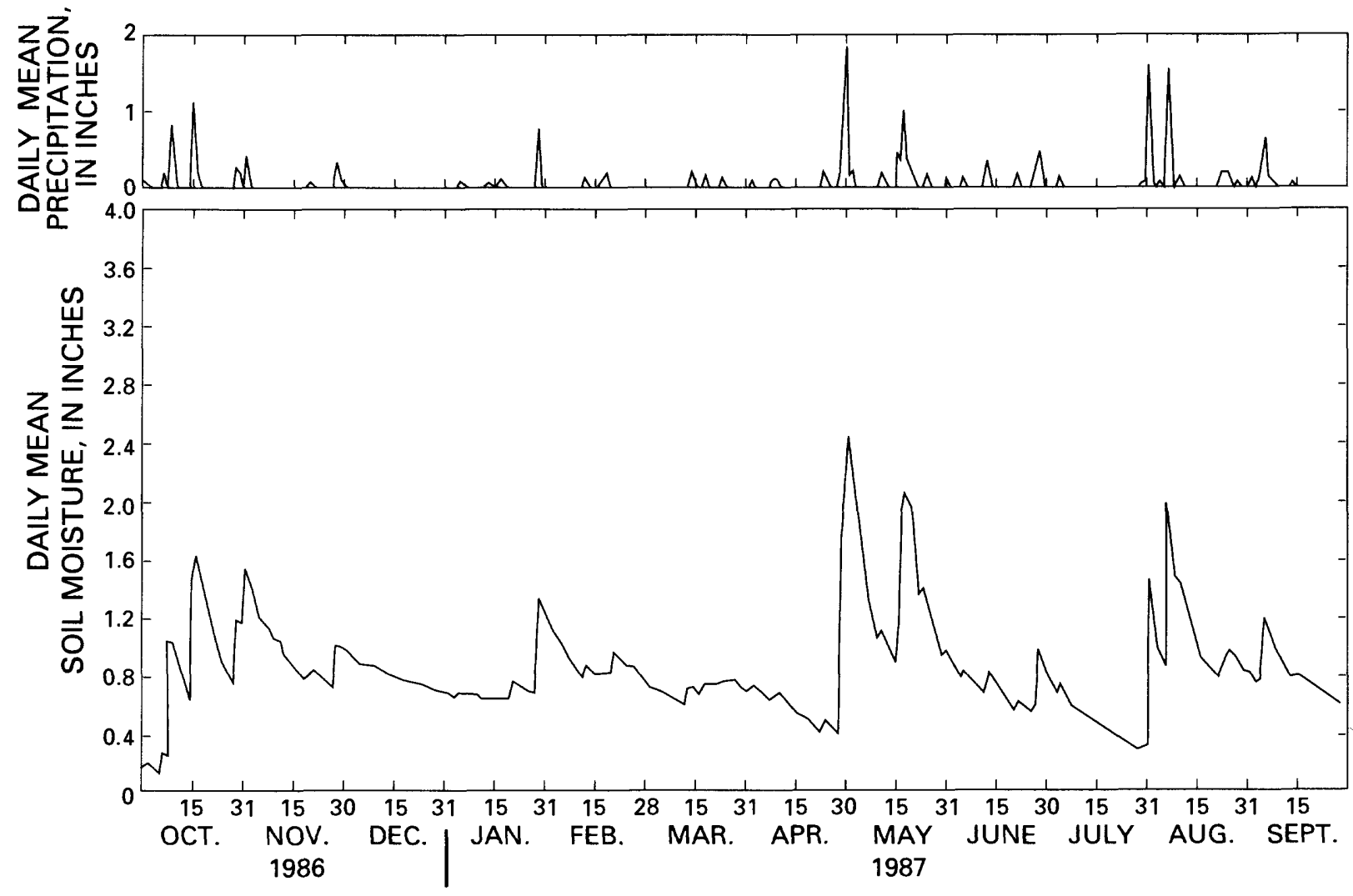

WATER YEAR 1987

Figure 15.--Daily mean precipitation and simulated soil moisture for the Taylor Arroyo drainage basin for water year 1987. 
Measured and simulated streamflow for water year 1987 at site S5 are compared in figure 16. Sixty percent of the runoff measured in water year 1987 resulted from a single storm on August 9. About 36 percent of the annual runoff volume occurred during May, June, and July and resulted from three additional storms.

The comparison of the measured and simulated hydrographs (fig. 16) indicates that the large storm of August 9, 1987, is simulated fairly well; the simulated daily mean streamflow of $76 \mathrm{ft}^{3} / \mathrm{s}$ compared reasonably to the measured streamflow of $82 \mathrm{ft}^{3} / \mathrm{s}$ ( $\mathrm{fig} .16$ ); this value is about an 8 percent difference. Good comparison exists between the measured and simulated daily mean streamflow during the smaller storms that occurred during October 1986 and May 1987. An exception to the overall good comparison occurred on July 2. On this date, the measured daily mean streamflow was $22 \mathrm{ft}^{3} / \mathrm{s}$, and the daily mean streamflow simulated by the model was $0.0 \mathrm{ft}^{3} / \mathrm{s}$. Why the outflow from this storm is not simulated accurately is not known. Antecedent soil moisture and the timing and spatial distribution of the precipitation probably are contributing factors to the lack of simulation.

\section{Calibration of Precipitation-Runoff Modeling System in the Unit Mode}

The PRMS modeling system can be used in a unit mode to simulate individual storms. In this mode, simulation time steps are 15 minutes instead of 24-hours. In the unit mode, PRMS routes the water from uplands as overland flow into channels and through the channels to the drainage-basin outlet (streamflow-gaging station).

Parameters from the calibrated daily model were used in the unit mode. The daily model was completed to the end of August 8, 1987, and provided the initial conditions for the unit mode. The nine HRU's defined for the daily model were used in the unit mode, but additional data were needed to route the streamflow through the drainage basin. Within each HRU, channels were defined (fig. 17).

The only storm that was available for simulation was the storm of August 9, 1987. Precipitation data taken at 15-minute intervals were available for the August 9 storm at the nine precipitation gages in the drainage basin (table 20). Streamflow for August 9 and 10, 1987, were available at 15-minute intervals for the streamflow-gaging station at Taylor Arroyo below Rock Crossing, near Thatcher (site S5) (p1. 1).

The effects of many small stock ponds and natural depressions in the drainage basin were not explicitly simulated in the model but were implicitly included in initial losses to the subsurface from each overland-flow plane (THRES). Because overland-flow planes are long, rainfall excess was calculated for each plane, and this excess was delivered directly to the associated channel in the simulation. 

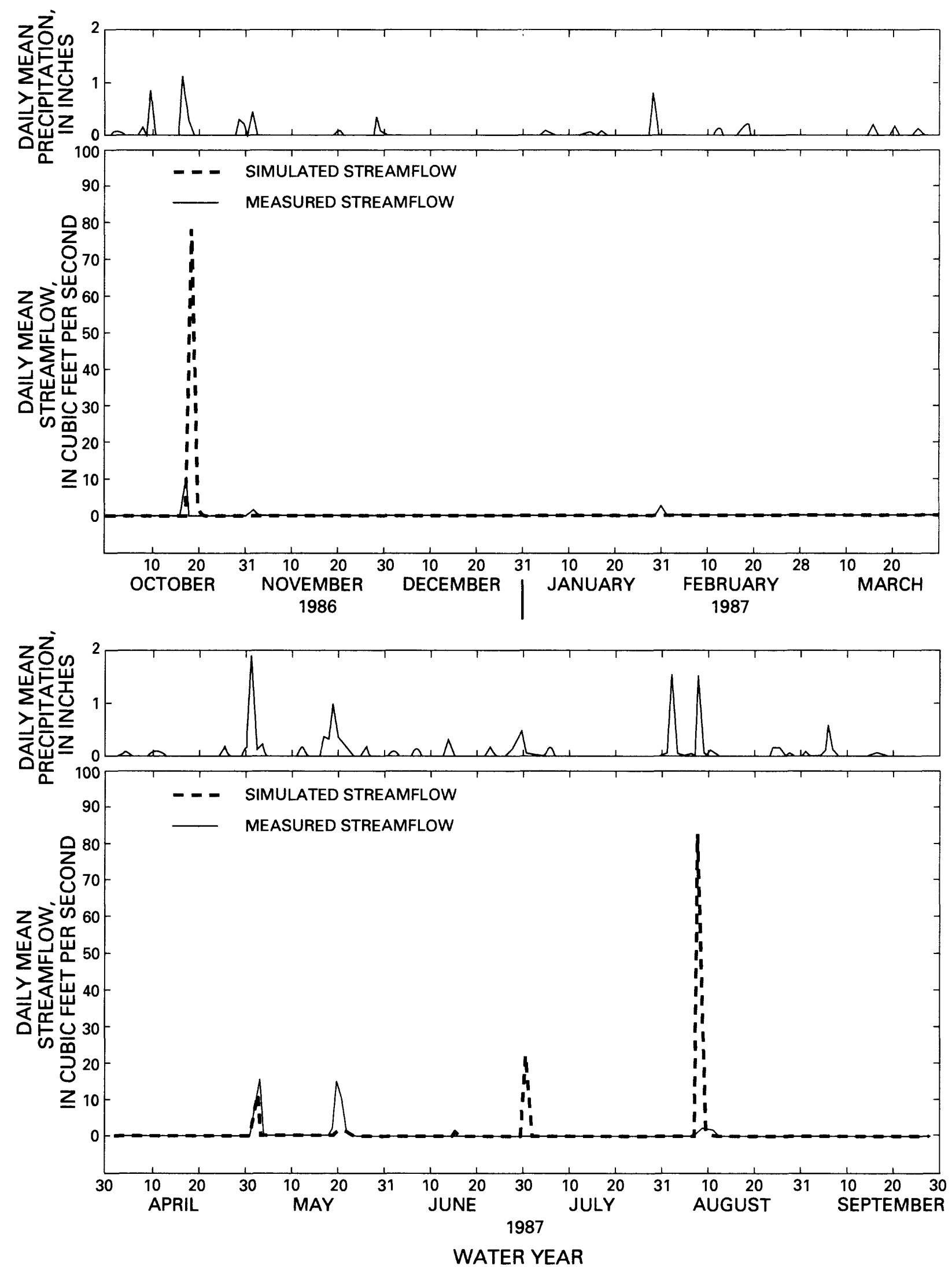

Figure 16.--Daily mean precipitation and measured and simulated streamflow for the Taylor Arroyo drainage basin for water year 1987. 


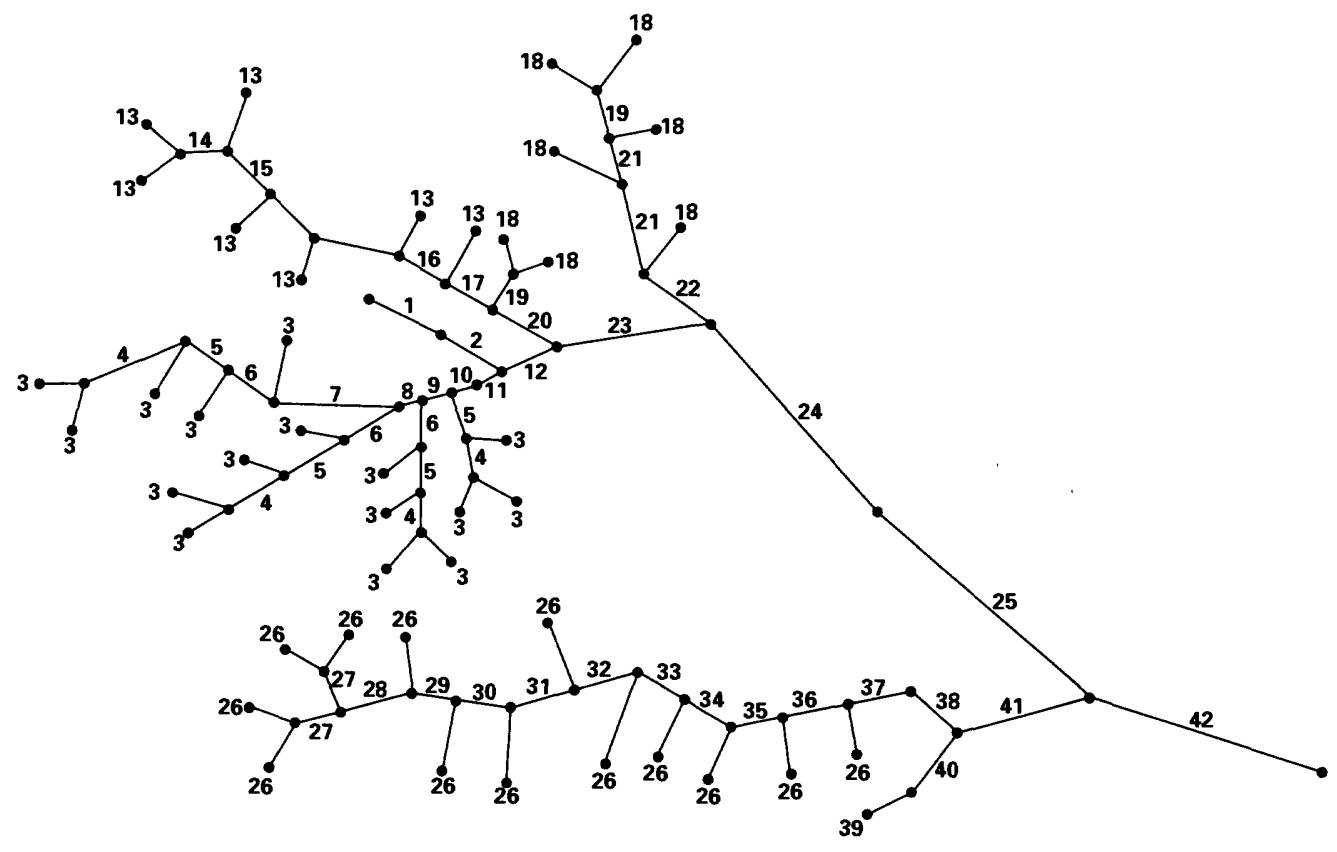

EXPLANATION

$\stackrel{33}{\longrightarrow}$ CHANNEL SEGMENT AND NUMBER

Figure 17.--Channel segmentation for hydrologic response units in the Taylor Arroyo drainage basin.

Mean precipitation throughout the entire drainage basin for the August 9 , 1987, storm was 1.87 in. The precipitation had an average duration of about 2.7 hours, and had an average intensity of $0.60 \mathrm{in} / \mathrm{h}$. Most of the precipitation occurred between 0300 and 0600 hours (fig. 18), and total precipitation ranged from 0.90 to $3.50 \mathrm{in.}$. Analysis of an isohyetal map of the storm indicates that most of the precipitation occurred in HRU's 4, 7, 8, and 9 (fig. 19).

Volume parameters that were adjusted in the calibration process include hydraulic conductivity of the transmission zone (KSAT) and losses to the subsurface from the overland-flow plane (THRES). Channel-roughness parameters that were adjusted include kinematic-wave parameters ALPHA and RM, which are the coefficients in the relation between depth of flow and discharge for the channels from the equation:

$$
Q=\operatorname{ALPHA}\left(\mathrm{A}^{\mathrm{RM}}\right)
$$

where $Q=$ streamflow, in cubic feet per second;

$A=$ area of cross section of channel, in square feet; and

ALPHA and RM = kinematic-wave parameters (Leavesley and others, 1983).

A summary of ALPHA and RM for each channel segment is listed in table 23. 

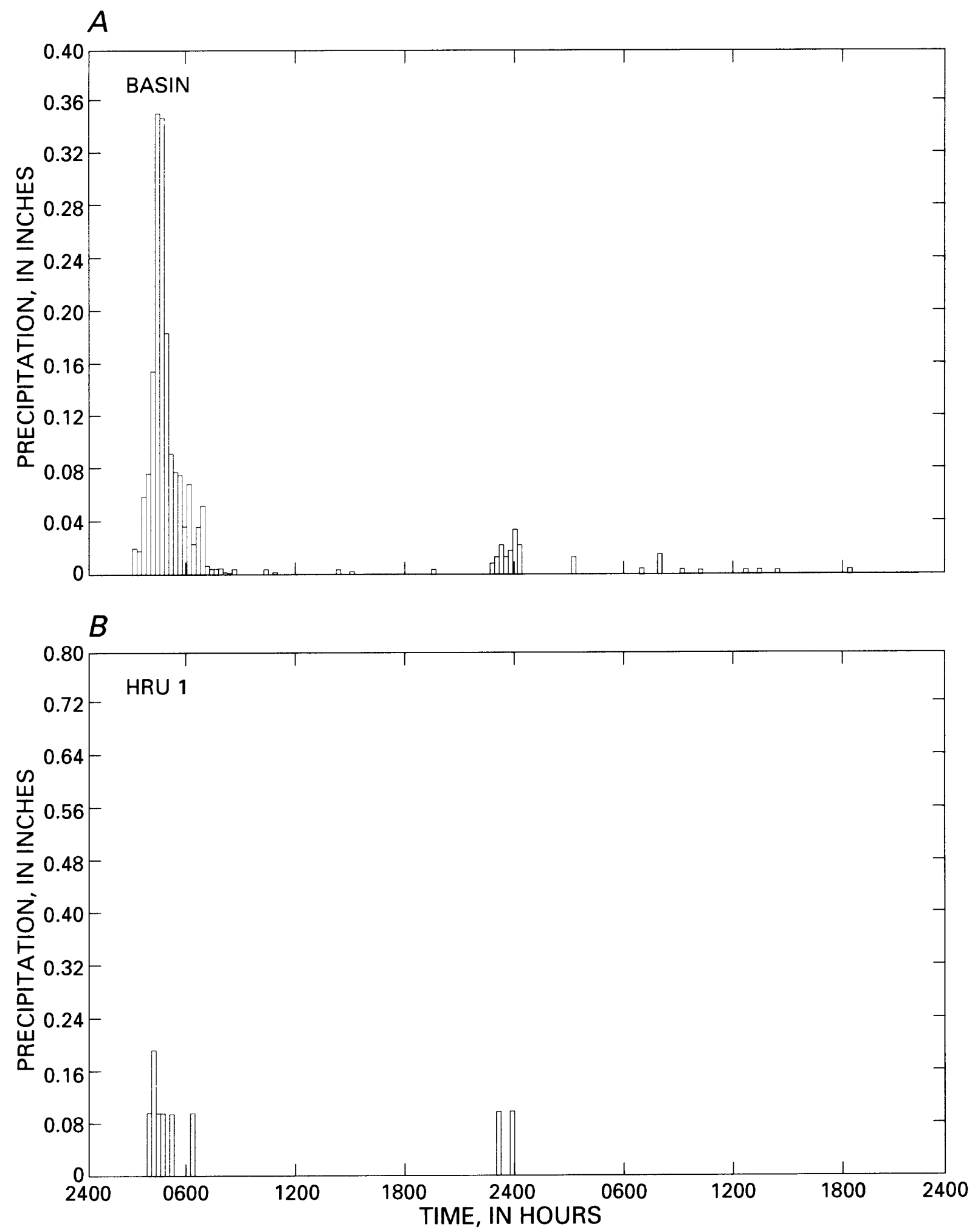

AUGUST 9, 1987

AUGUST 10, 1987

Figure 18.--Hyetographs for basin mean precipitation and for individual hydrologic response units (HRU) in the Taylor Arroyo drainage basin for August 9-10, 1987. (Area weighted unit precipitation is at 15-minute intervals.) 

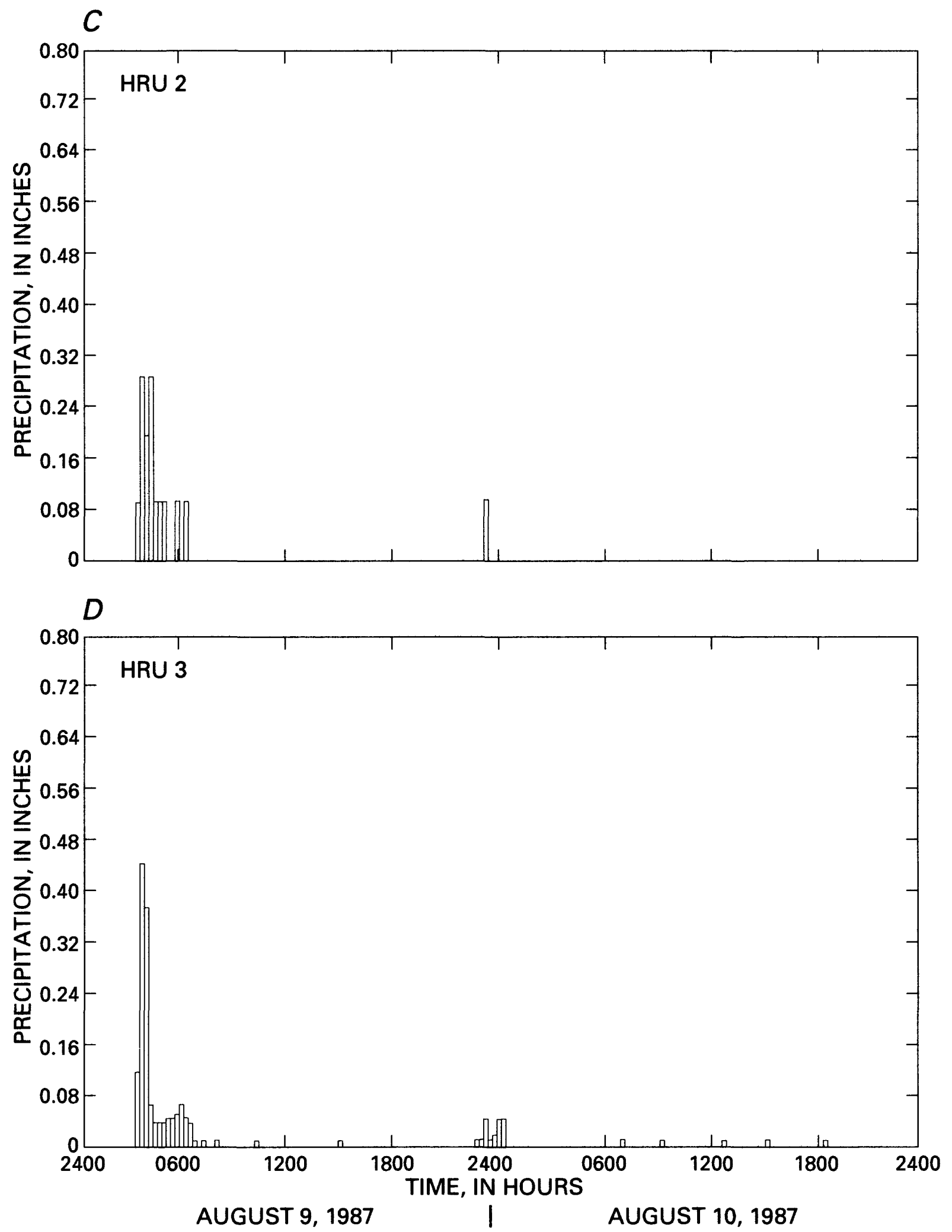

Figure 18.--Hyetographs for basin mean precipitation and for individual hydrologic response units (HRU) in the Taylor Arroyo drainage basin for August 9-10, 1987. (Area weighted unit precipitation is at 15-minute intervals)--Continued. 

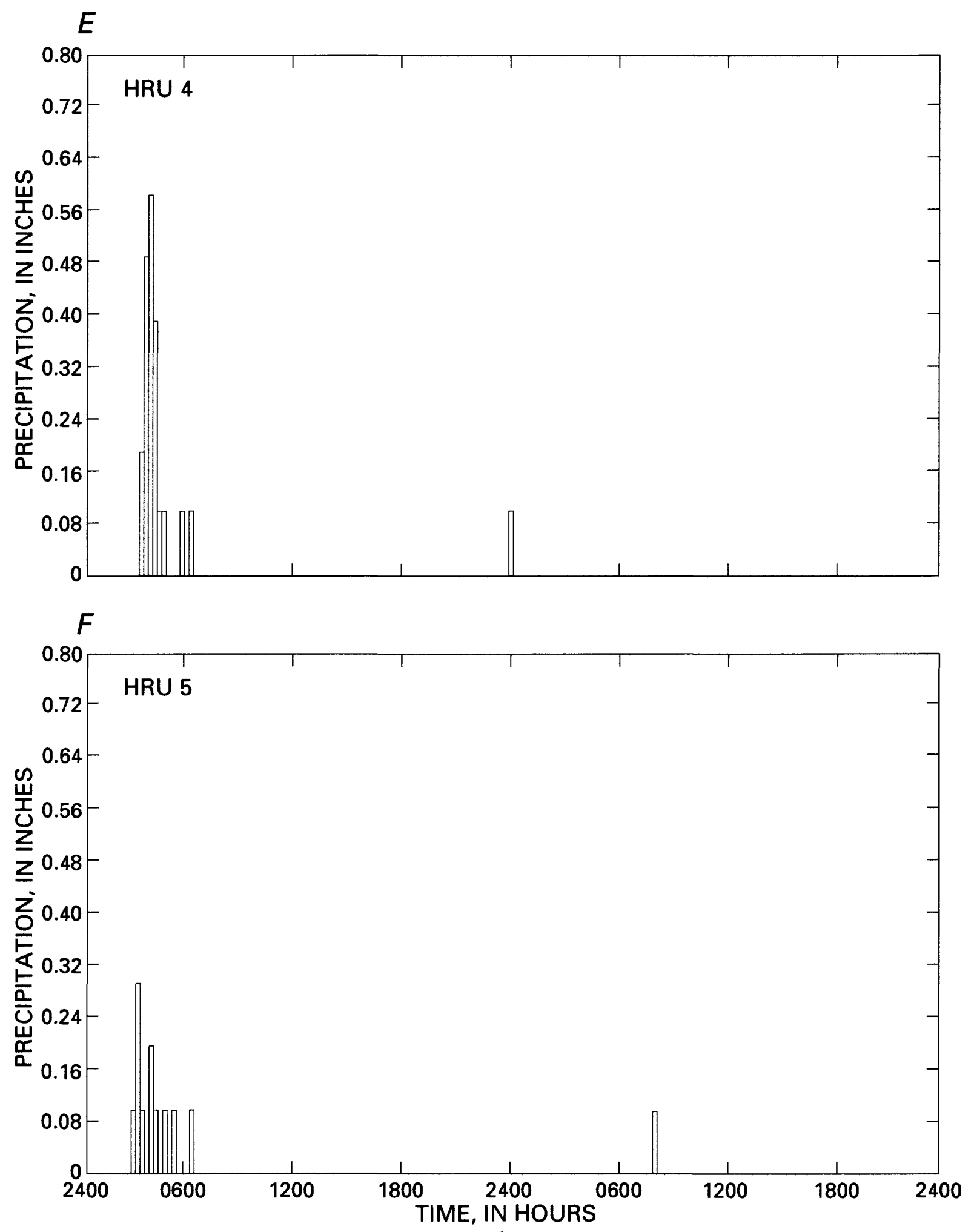

AUGUST 9, 1987

AUGUST 10, 1987

Figure 18.--Hyetographs for basin mean precipitation and for individual hydrologic response units (HRU) in the Taylor Arroyo drainage basin for August 9-10, 1987. (Area weighted unit precipitation is at 15-minute intervals)--Continued. 

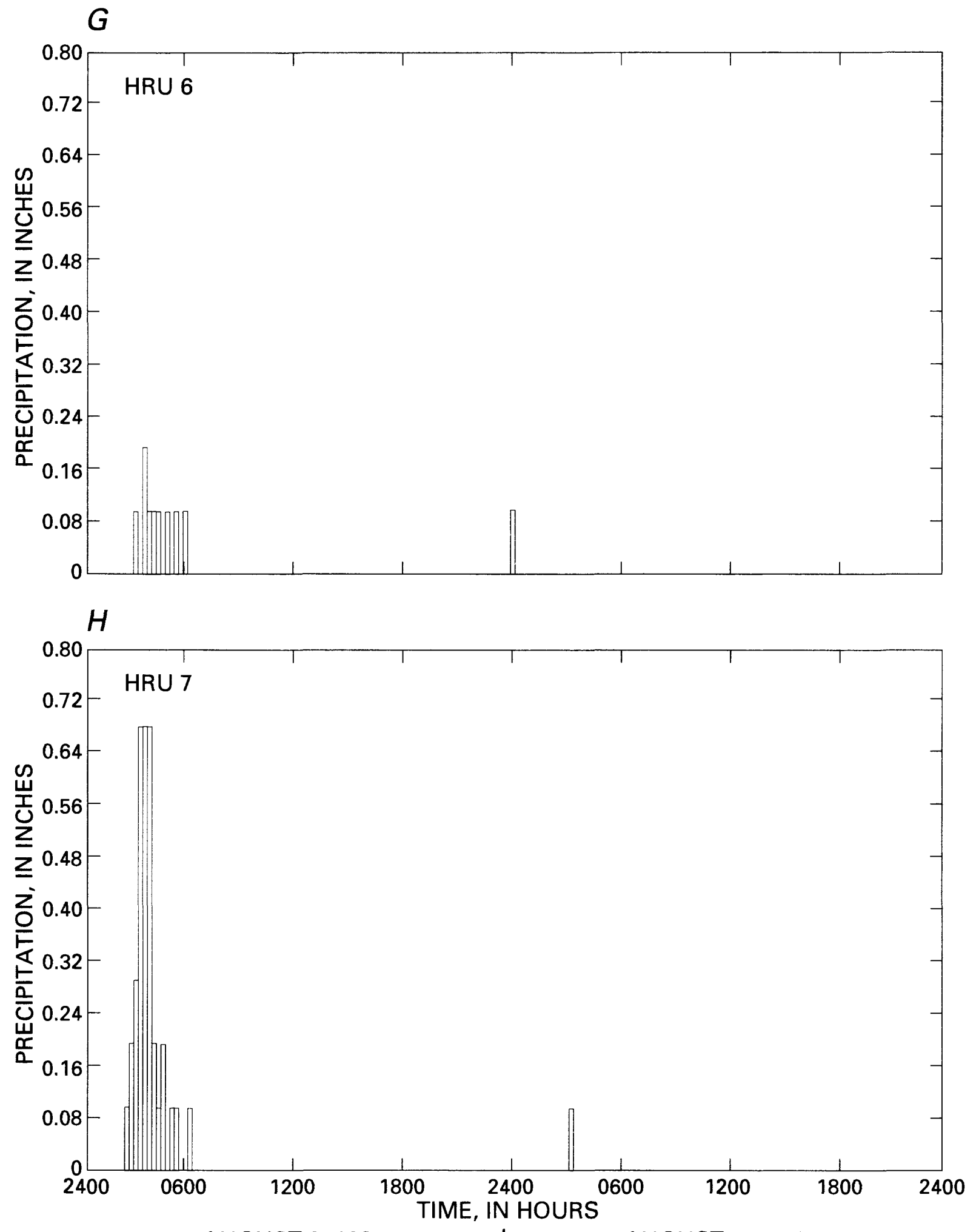

AUGUST 9, 1987

AUGUST 10, 1987

Figure 18.--Hyetographs for basin mean precipitation and for individual hydrologic response units (HRU) in the Taylor Arroyo drainage basin for August 9-10, 1987. (Area weighted unit precipitation is at 15-minute intervals)--Continued. 

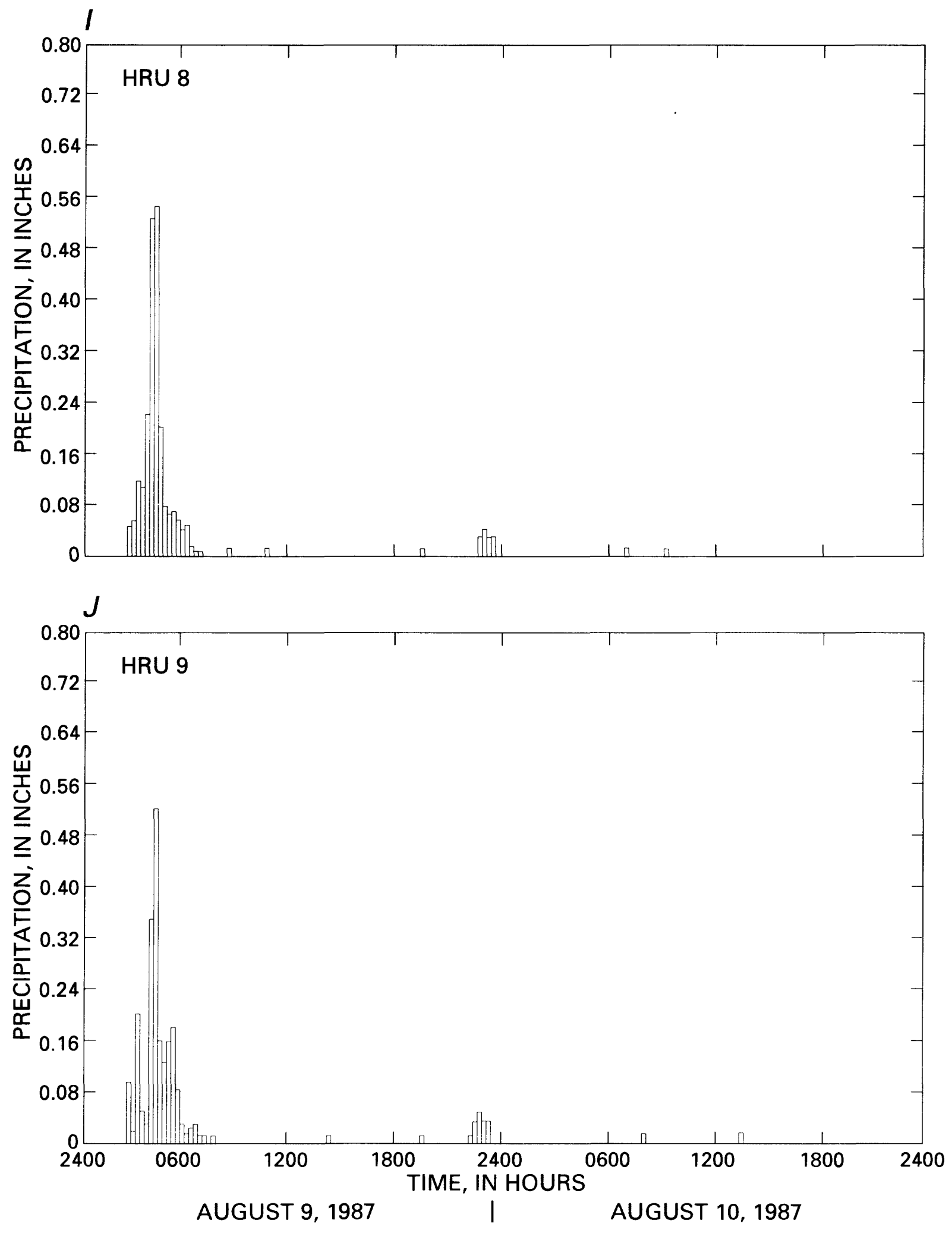

Figure 18.--Hyetographs for basin mean precipitation and for individual hydrologic response units (HRU) in the Taylor Arroyo drainage basin for August 9-10, 1987. (Area weighted unit precipitation is at 15-minute intervals)--Continued. 


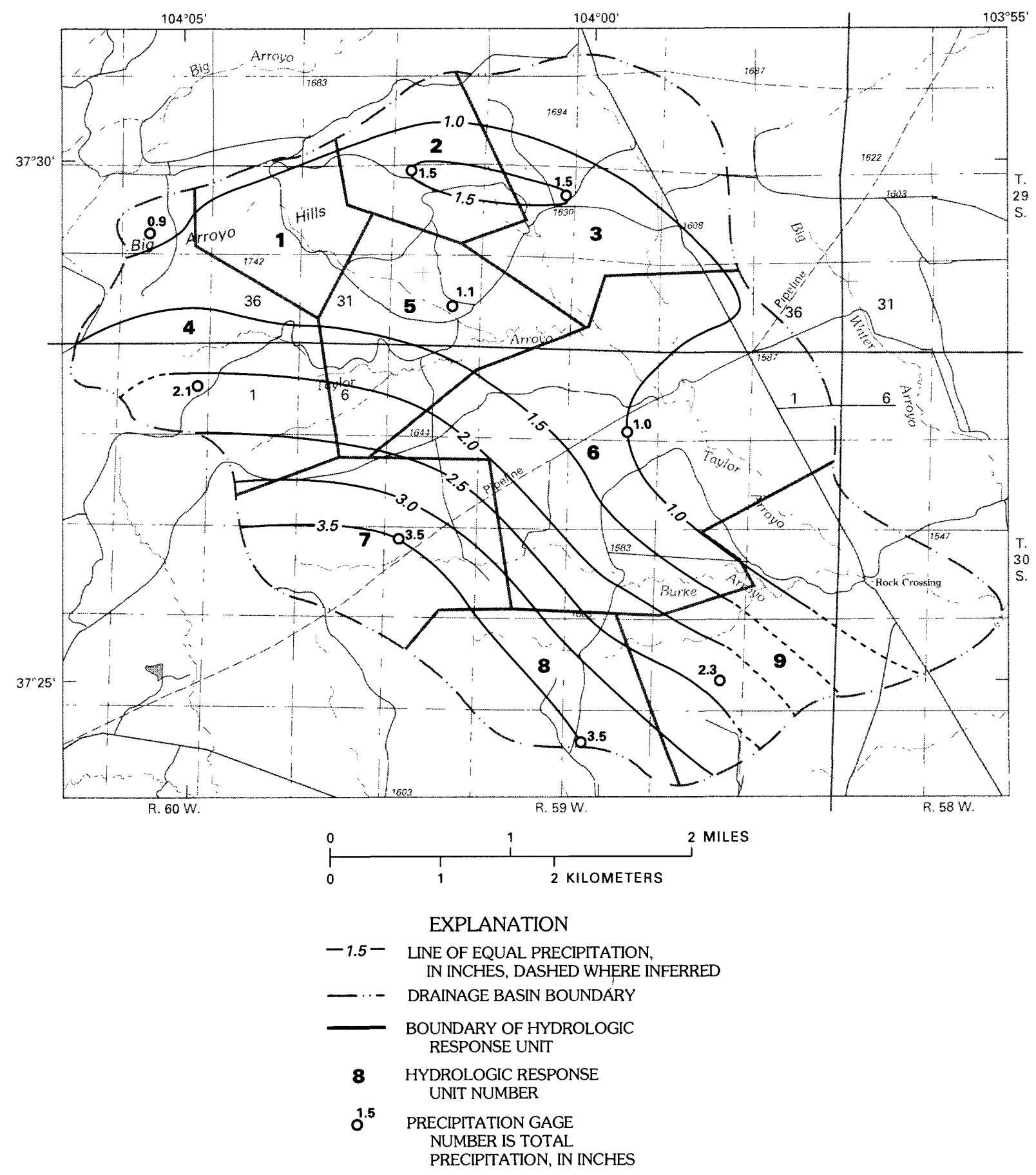

Figure 19.--Precipitation for August 9-10, 1987, in the Taylor Arroyo drainage basin. 
Table 23.--Characteristics of channel segments defined for unit mode of the Precipitation-Runoff Modeling System for the Taylor Arroyo drainage basin

\begin{tabular}{|c|c|c|c|}
\hline $\begin{array}{c}\text { Channel segment number } \\
\text { in figure } 17\end{array}$ & $\begin{array}{l}\text { Length } \\
\text { (feet) }\end{array}$ & \multicolumn{2}{|c|}{$\frac{\text { Kinematic wave parameters }}{\text { ALPHA }^{1}}$} \\
\hline 1 & 8,474 & 0.60 & 1.67 \\
\hline 2 & 10,138 & .30 & 1.67 \\
\hline 3 & 2,100 & .60 & 1.67 \\
\hline 4 & 2,000 & .30 & 1.67 \\
\hline 5 & 2,000 & .30 & 1.67 \\
\hline 6 & 2,100 & .30 & 1.67 \\
\hline 7 & 2,000 & .30 & 1.67 \\
\hline 8 & 2,000 & .20 & 1.67 \\
\hline 9 & 2,000 & .20 & 1.67 \\
\hline 10 & 2,000 & .20 & 1.67 \\
\hline 11 & 10,365 & .10 & 1.67 \\
\hline 12 & 6,896 & .10 & 1.67 \\
\hline 13 & 3,100 & .60 & 1.67 \\
\hline 14 & 2,000 & .30 & 1.67 \\
\hline 15 & 2,000 & .20 & 1.67 \\
\hline 16 & 2,000 & .15 & 1.67 \\
\hline 17 & 2,000 & .15 & 1.67 \\
\hline 18 & 4,500 & .60 & 1.67 \\
\hline 19 & 2,000 & .30 & 1.67 \\
\hline 20 & 2,000 & .10 & 1.67 \\
\hline 21 & 2,000 & .20 & 1.67 \\
\hline 22 & 2,000 & .15 & 1.67 \\
\hline 23 & 8,200 & .10 & 1.67 \\
\hline 24 & 8,596 & .10 & 1.67 \\
\hline 25 & 6,399 & .05 & 1.67 \\
\hline 26 & 2,000 & .60 & 1.67 \\
\hline 27 & 1,500 & .30 & 1.67 \\
\hline 28 & 1,500 & .20 & 1.67 \\
\hline 29 & 1,500 & .15 & 1.67 \\
\hline 30 & 1,500 & .15 & 1.67 \\
\hline 31 & 1,500 & .15 & 1.67 \\
\hline 32 & 1,500 & .12 & 1.67 \\
\hline 33 & 1,500 & .12 & 1.67 \\
\hline 34 & 1,500 & .12 & 1.67 \\
\hline 35 & 1,500 & .10 & 1.67 \\
\hline 36 & 1,500 & .10 & 1.67 \\
\hline 37 & 1,500 & .08 & 1.67 \\
\hline 38 & 16,379 & .05 & 1.67 \\
\hline 39 & 10,872 & .20 & 1.67 \\
\hline 40 & 9,298 & .10 & 1.67 \\
\hline 41 & 4,995 & .03 & 1.67 \\
\hline 42 & 11,405 & .02 & 1.67 \\
\hline
\end{tabular}

${ }^{1} \mathrm{~A}$ value of 1.67 is suggested for turbulent flow (G.H. Leavesley, U.S. Geological Survey, oral commun., 1988). 
The adjustment of timing of the streamflow hydrograph was difficult. Seventy one to 91 percent of the rainfall for the nine precipitation gages occurred before 0500 hours. The measured streamflow at site 55 did not reach $1.0 \mathrm{ft}^{3} / \mathrm{s}$ until 0800, and the measured streamflow peak occurred at 0900 . This delay proved troublesome for the mathematical routing technique used in the model. Future drainage-basin modeling may need to investigate other routing methods for this drainage basin to improve the correlation between the timing of measured and simulated hydrographs.

The comparison of the measured and simulated streamflow volumes indicates that the volume in the simulated streamflow is larger by 0.05 in. The volume of the measured outflow was 0.06 in., and the volume of the simulated outflow was $0.11 \mathrm{in}$. The measured peak streamflow was $669 \mathrm{ft}^{3} / \mathrm{s}$ and occurred at about 0900. The simulated peak streamflow was $650 \mathrm{ft}^{3} / \mathrm{s}$, a difference of 3 about percent, and occurred also at about 0900 (fig. 20).

The shape of the measured and simulated hydrographs are slightly different. The rising limb of the measured hydrograph is steeper, and measured streamflow occurs later than in the simulated hydrograph. The measured hydrograph has a steeper recession than in the simulated hydrograph. Both of these differences relate to the increased volume of water indicated by the simulated hydrograph and are the result of the lack of an algorithm to account for channel losses. Channel losses are an important component in this drainage basin

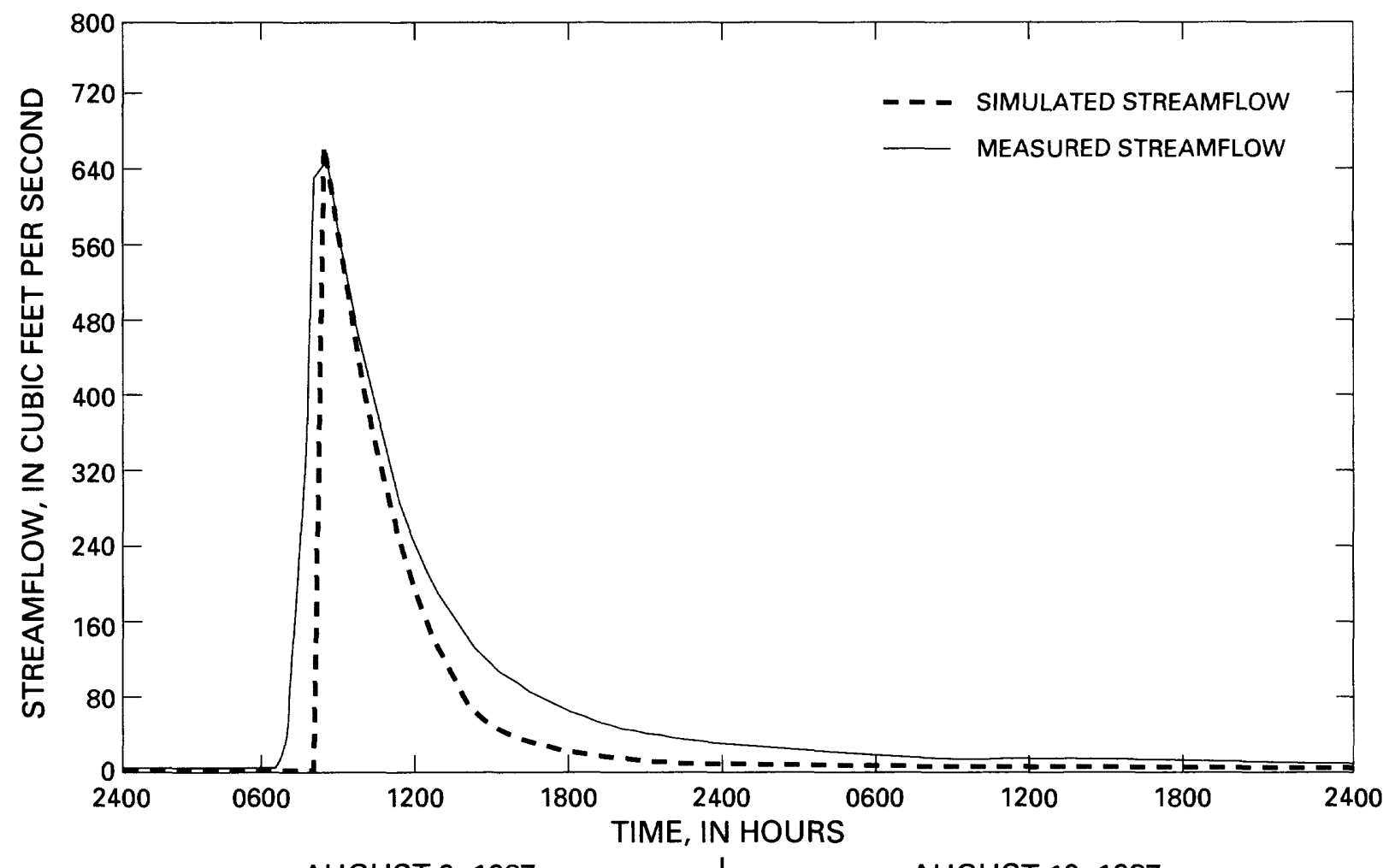

AUGUST 9, 1987

AUGUST 10, 1987

Figure 20.--Measured and simulated streamflow for August 9-10, 1987, in the Taylor Arroyo drainage basin. 
(von Guerard and others, 1987). Future modeling needs to include methods to calculate channel losses, and future data collection needs to include efforts to determine the magnitude of this component.

\section{Changes in the Storm Hydrograph with Increased Military Maneuvers}

The simulated hydrograph from the model for the storm of August 9, 1987, indicates existing conditions at the Maneuver Site. However, because of the lack of rainfall runoff during water year 1987 , the results obtained (simulated hydrographs) are not derived from a calibrated model but from a model calibrated to the single storm.

The question posed is, what would be the effect of increased military maneuvers on this particular hydrograph? Model parameters can be changed, and simulations of this same storm can be done and compared with the simulated hydrograph already produced. For this comparison, the parameters in the model that would change and the magnitude of that change need to be identified.

A study was done on the Fort Carson Military Reservation, about $40 \mathrm{mi}$ northwest of Pueblo, to examine the effects of tracked vehicles on the physical characteristics of the soil (Camp, Dresser, and McKee, Inc., 1984). Changes in soil compaction were determined by bulk-density measurements. Measurements were obtained from tracked and untracked areas on hilly areas that were lightly forested with pinon-juniper. The mean bulk density of 11 measurements of the total soil profile obtained in the tracked areas was $1.46 \mathrm{~g} / \mathrm{cm}^{3}$, and the standard deviation was $0.17 \mathrm{~g} / \mathrm{cm}^{3}$. The mean bulk density of 12 measurements of the total soil profile obtained in untracked areas was $1.30 \mathrm{~g} / \mathrm{cm}^{3}$, and the standard deviation was $0.26 \mathrm{~g} / \mathrm{cm}^{3}$. The difference in the mean bulk density between tracked and untracked areas in the pinon-juniper was about 12 percent.

A total of 24 additional samples were obtained from gently rolling grasslands. The mean bulk density of the 12 measurements of the total soil profile obtained from the tracked areas was $1.52 \mathrm{~g} / \mathrm{cm}^{3}$, and the standard deviation was $0.11 \mathrm{~g} / \mathrm{cm}^{3}$. In the untracked areas of the grasslands, the mean bulk density was $1.46 \mathrm{~g} / \mathrm{cm}^{3}$, and the standard deviation was $0.15 \mathrm{~g} / \mathrm{cm}^{3}$. Therefore, the difference in the mean bulk density between tracked and untracked areas in the grasslands was about 4 percent. Most of the increase in compaction due to the tracked vehicles occurred in the A soil horizon, in which there was an average increase of 18 percent in the bulk density in the grasslands and in the pinonjuniper areas (Camp, Dresser, and McKee, Inc., 1984).

The parameter KSAT, the hydraulic conductivity, can be decreased by increases in soil compaction (Rawls and Brakensiek, 1983). These authors provide diagrams of changes in KSAT for specific changes in porosity. Bulk density is related to porosity by:

$$
P=\left(1-\frac{R}{2.65}\right)
$$

where $P=$ porosity; and

$\mathrm{R}=$ bulk density. 
Thus, changes defined for bulk density can be related to changes in porosity. Based on measurements of bulk density from the Fort Carson Military Reservation, decreases of 10 percent in porosity, caused by increased soil bulk density, seem reasonable for disturbance by tracked vehicles. Therefore, for an HRU and specific soil type, a value for KSAT for a 10-percent change in porosity can be identified using methods described by Rawls and Brakensiek (1983).

To adjust KSAT values in the calibrated model to changes in soil bulk density resulting from disturbance by tracked vehicles, a KSAT ratio was computed. This ratio was KSAT at a 10-percent decrease in porosity divided by the base KSAT for each soil type. Both these values in the ratio are from the diagrams given by Rawls and Brakensiek (1983). The ratio for each soil type then is applied to the KSAT values in the calibrated model to yield KSAT values for disturbed areas. Using this ratio provides a relative index in the change of KSAT values with disturbance. The diagrams from Rawls and Brakensiek (1983) reflect saturated conductivity and cannot be used directly as values of KSAT (Morel-Seytoux and Khanji, 1974).

The disturbance caused by tracked vehicles occurs in only a small percentage of each HRU, and the KSAT value for undisturbed and for disturbed areas is area weighted to provide a mean KSAT value for each HRU. To define existing land-use conditions, the percentage of area disturbed was determined by inspection of the Maneuver Site and by data collected for vegetation surveys (R.S. Shaw, Colorado State University, written commun., 1987). For this example, the percentage of disturbed area, in each HRU, was assumed to be distributed similarly to the conditions observed during visual inspection and vegetation surveys at the Maneuver Site. The values of KSAT before and after the 10-percent decrease in porosity are listed in table 24. These mean values of KSAT are used in the model to indicate increased military maneuvers. This approach is qualitative; a more detailed analysis of area affected by military maneuvers is needed for future modeling efforts.

Table 24.--Summary of information and hydraulic conductivity (KSAT) values for disturbed and undisturbed areas of each hydrologic response unit in the Taylor Arroyo drainage basin

[SL, silt loam; SCL, silt clay loam; L, loam]

\begin{tabular}{|c|c|c|c|c|c|c|c|}
\hline \multirow{2}{*}{$\begin{array}{l}\text { Hydrologic } \\
\text { response } \\
\text { unit }\end{array}$} & \multirow{2}{*}{$\begin{array}{c}\text { Soil } \\
\text { classi- } \\
\text { fication }\end{array}$} & \multirow{2}{*}{$\begin{array}{c}\text { Area } \\
\text { (square } \\
\text { miles) }\end{array}$} & \multicolumn{2}{|c|}{ Undisturbed } & \multicolumn{2}{|c|}{ Disturbed } & \multirow{2}{*}{$\begin{array}{l}\text { Area- } \\
\text { weighted } \\
\text { KSAT }\end{array}$} \\
\hline & & & $\begin{array}{c}\text { Area } \\
\text { (percent) }\end{array}$ & KSAT & $\begin{array}{c}\text { Area } \\
\text { (percent) }\end{array}$ & KSAT & \\
\hline 1 & SL-SCL & 1.96 & 85 & 4.33 & 15 & 2.65 & 4.08 \\
\hline 2 & SL-SCL & 2.78 & 99.8 & 4.33 & 0.2 & 2.65 & 4.33 \\
\hline 3 & SL-SCL & 6.39 & 95.3 & 4.33 & 4.7 & 2.65 & 4.25 \\
\hline 4 & SL-L & 6.15 & 99.5 & 2.18 & .5 & 1.37 & 2.18 \\
\hline 5 & SL-L & 4.36 & 98.2 & 2.18 & 1.8 & 1.37 & 2.16 \\
\hline 6 & $S L-L$ & 11.5 & 99.0 & 2.18 & 1.0 & 1.37 & 2.17 \\
\hline 7 & $S L-\bar{L}$ & 5.00 & 98.6 & 3.74 & 1.4 & 2.35 & 3.72 \\
\hline 8 & $\mathrm{SL}-\mathrm{SCL}$ & 3.35 & 97.6 & 3.74 & 2.4 & 2.29 & 3.70 \\
\hline 9 & SL-SCL & 7.19 & 96.8 & 3.74 & 3.2 & 2.29 & 3.69 \\
\hline
\end{tabular}


The model was rerun for the storm of August 9, 1987. The only change made in parameter values were those to KSAT. When compared to the simulated peak streamflow for existing land-use conditions (fig. 21), the simulated peak streamflow for hypothetical increased military maneuvers increased from 650 to $658 \mathrm{ft}^{3} / \mathrm{s}$, or about 1.2 percent. The change probably indicates the direction of change that would be measured as disturbance increased from military maneuvers. Increased effects from military maneuvers of the level described probably would have minimal effect on streamflow. However, the magnitude of the change simulated may not indicate actual conditions. Because the model has been fit to only one storm, calibration of the model parameters cannot be verified against existing conditions. The hydrograph that results from changes in parameter values is a result of the sensitivity of each parameter within the model and of any actual change that may occur.

To obtain a calibrated model, the model parameters need to be assessed by using a series of storms and corresponding runoff events of various sizes. In a semiarid environment, the temporal and spatial variability of these storms are such that 5 to 10 years may be required before an adequate number of storms occur for model calibration. The sequence of steps used in this report could be used with a calibrated model to identify the streamflow changes caused by disturbance in the drainage basin.

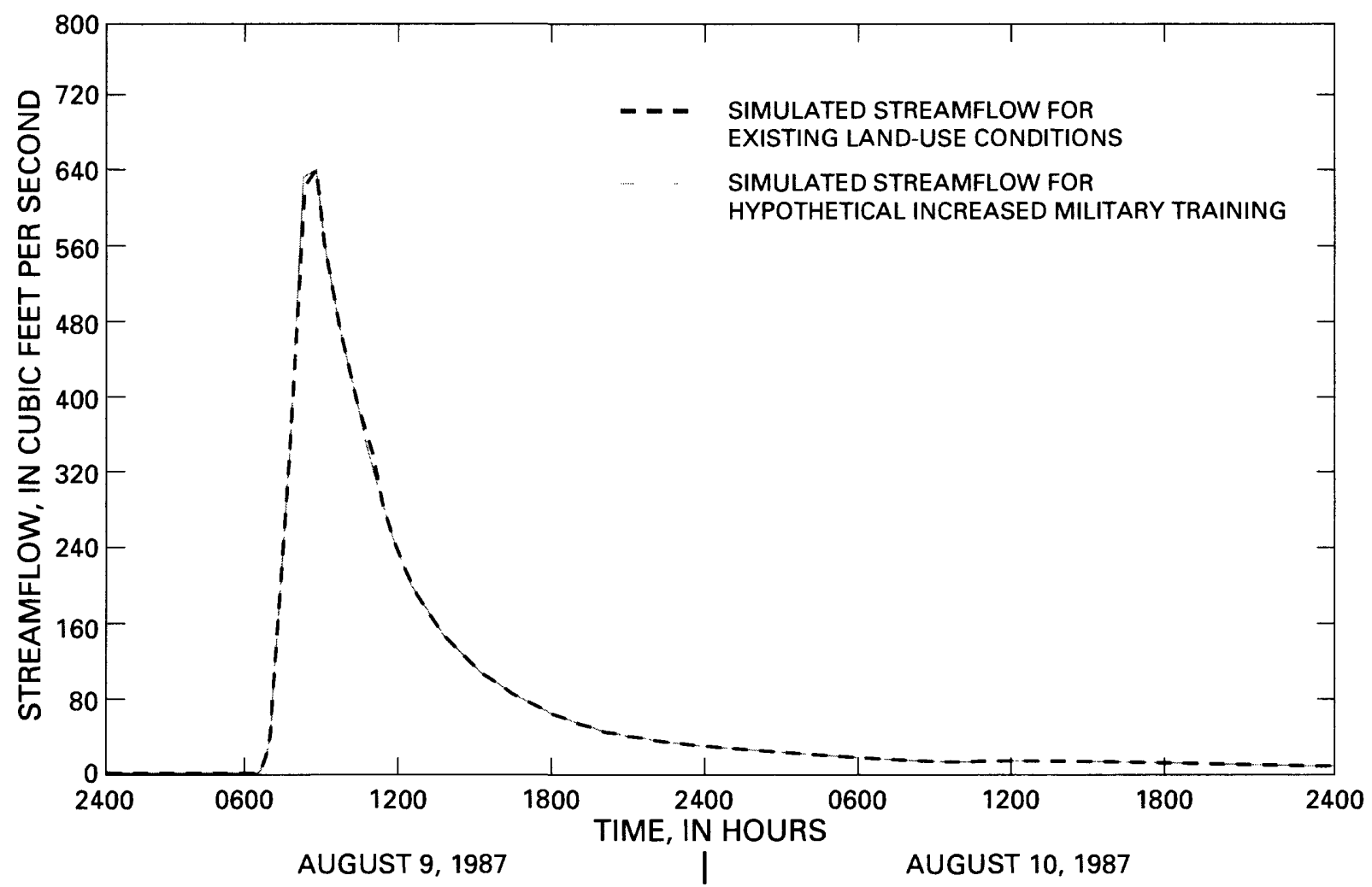

Figure 21.--Simulated streamflow hydrograph for existing land-use conditions and hypothetical increased military training for August 9-10, 1987, in the Taylor Arroyo drainage basin. 
The U.S. Department of the Army began military maneuvers on the $381-\mathrm{mi}^{2}$ Pinon Canyon Maneuver Site in July 1985; six training rotations occurred between the five training areas from July 1985 through November 1987 . The effects of military maneuvers on the surface water of the Maneuver Site and on the Purgatoire River are of concern to the military and to downstream water users. Data collected during the baseline assessment of surface-water conditions at the Maneuver Site provide the period of reference for assessing the effects of military maneuvers on the surface water of the area. Specifically, the period of data analyzed was divided into a premaneuver period (through July 31,1985 ) and a postmaneuver period (after July 31, 1985).

The temporal and spatial distribution of precipitation in the semiarid environment causes problems for the land manager. To effectively rehabilitate land that may be damaged by military maneuvers, the characteristic variability of precipitation at the Maneuver Site needs to be understood. Temporal and spatial distribution of precipitation affects the vigor of existing vegetation and the natural recovery of damaged lands and, thus, the extent that damaged lands will affect the surface water at the Maneuver Site.

Monthly precipitation data are available for the Maneuver Site from August 1983 through September 1987 at four sites, and seasonal precipitation data for the water year 1987 are available for July through September for the nine sites in Taylor Arroyo drainage basin. For the purposes of understanding any changes in streamflow between pre- and postmaneuver periods, change in precipitation between the periods was analyzed using the seasonal rank-sum test. Analysis of monthly mean precipitation for the four sites indicated that no significant difference $(p>0.05)$ in monthly mean precipitation existed between the pre- and postmaneuver periods.

Monthly precipitation for November through March at the Maneuver Site usually was less than 1 in. Monthly mean precipitation during April through June usually was less than 2 in.; however, monthly precipitation amounts of greater than 2 in. are not uncommon. Monthly precipitation at the Bent Canyon gage for May 1987 was 6.17 in.; when compared to precipitation data for the Las Animas County Airport, the May 1987 monthly precipitation of 6.17 in. was exceeded once at the Airport during the period of record (1947-87). Precipitation during July through September resulted largely from convective storms. Monthly mean precipitation during July through September usually was greater than 1 in. Comparison of precipitation records at the Maneuver Site with long-term records for the Las Animas County Airport indicates generally drier than long-term conditions for July and September and wetter than long-term conditions for August.

Recent trends in streamflow in the Purgatoire River were analyzed by using monthly streamflow data for the Purgatoire River near Thatcher (site S4) and the Purgatoire River at Rock Crossing, near Timpas (site S10). The significance of trend in monthly streamflow at each site was determined by using the seasonal rank-sum test. There was no significant difference $(p>0.05)$ in monthly streamflow at sites $\mathrm{S} 4$ and $\mathrm{S} 10$ between pre- and postmaneuver periods. Therefore, any increase or decrease in streamflow that resulted from military land use at the Maneuver Site and any increase or decrease in streamflow from Chacuaco Creek at mouth, near Timpas (site S8), cannot be detected by analysis of the streamflow data at sites $\mathrm{S} 4$ and $\mathrm{S} 10$. 
Daily streamflow data are available for Chacuaco Creek at mouth, near Timpas (site S8). There was no significant difference ( $p>0.05)$ in monthly streamflow at site 58 between the pre- and postmaneuver periods. Estimated peak discharges for certain recurrence intervals were 0 to 40 percent less than previous estimates because of the construction of erosion-control dams.

Daily streamflow data for streams that drain the Maneuver Site are available for Big Arroyo near Thatcher (site S1); Van Bremer Arroyo near Model (site S3); Taylor Arroyo below Rock Crossing, near Thatcher (site S5);

Lockwood Canyon Creek near Thatcher (site S6); Red Rock Canyon Creek at mouth, near Thatcher (site S7); and Bent Canyon Creek at mouth, near Timpas (site S9). A significant increase $(\mathrm{p}<0.05)$ occurred at site S3 for monthly streamflow that includes the effects of irrigation return flow and for monthly streamflow minus the effects of irrigation return flows. The p-values for the base streamflow period (November through March) and the summer streamflow period (July through 0ctober) (only with irrigation return flow) at site S3 indicated there was a significant difference $(p<0.05)$ in monthly streamflow between the pre- and postmaneuver periods. This increase may be a result of water being stored in channel alluvium and in streambanks during periods of irrigation return flow and of its subsequent release during periods of base and summer streamflow. No significant difference ( $p>0.05)$ occurred in monthly streamflow at site S6. The combined monthly streamflow for all ephemeral streams on the Maneuver Site indicated no significant difference $(p>0.05)$ between pre- and postmaneuver periods.

Dissolved oxygen and flow-adjusted concentrations of selected waterquality constituents for the Purgatoire River near Thatcher (site S4) and the Purgatoire River at Rock Crossing, near Timpas (site S10), were tested for changes between the pre- and postmaneuver periods by using the seasonal rank-sum test. Except for total-recoverable zinc at site S4, there was no significant difference $(\mathrm{p}>0.05)$ in dissolved oxygen or in any of the selected water-quality constituents between the pre- and postmaneuver periods.

Instream standards for total-recoverable cadmium, copper, iron, lead, manganese, and zinc were exceeded for sites S4 and S10 during periods of streamflow that had large concentrations of suspended sediment; these periods usually were associated with snowmelt and rainfall runoff. Otherwise, during periods of base streamflow, concentrations of total-recoverable metal of equalled or were less than the instream standards.

Daily mean specific-conductance data for water years 1984 through 1987 are available for the Purgatoire River near Thatcher (site S4) and for the Purgatoire River at Rock Crossing, near Timpas (site S10). Flow-adjusted monthly mean specific conductance at sites $\mathrm{S} 4$ and $\mathrm{S} 10$ was tested for change between pre- and postmaneuver periods by using the seasonal rank-sum test. No significant difference $(p>0.05)$ in monthly mean specific conductance was detected at sites S4 and S10. At Van Bremer Arroyo near Model (site S3), monthly mean specific conductance for periods of all streamflow and for periods of streamflow unaffected by irrigation return flow were analyzed for trend between the pre- and postmaneuver periods by using the seasonal rank-sum test. No significant difference $(p>0.05)$ in monthly mean specific conductance was detected for periods that included all streamflow and for periods that included streamflow minus irrigation return flow. No significant difference $(p>0.05)$ in monthly mean specific conductance between pre- and postmaneuver periods was detected at Lockwood Canyon Creek near Thatcher (site S6). 
Except at Van Bremer Arroyo near Model (site S3), no statistically significant change in streamflow quantity and quality was detected between the pre- and postmaneuver periods for the Purgatoire River and its tributaries in and near the Maneuver Site. However, the lack of detection of a statistically significant change may be attributable in part to the short period of record available for statistical analysis. The reliability of the statistical analysis would be greatly improved with additional years of record.

The effects of military maneuvers on sediment yields were evaluated by using a qualitative method for estimating mean annual sediment yields that was developed by the Pacific Southwest Inter-Agency Committee (PSIAC). Sediment yields were estimated for drainage basins above 28 stock-watering reservoirs in and near the Maneuver Site during 1983-84 prior to the start of military maneuvers. Twenty-one of these drainage basins are located on the Maneuver Site and seven are located off the Maneuver Site on adjacent rangeland. Drainage areas of these drainage basins range in size from 0.10 to $1.2 \mathrm{mi}^{2}$.

During November 1987, sediment yields were estimated for the 21 drainage basins on the Maneuver Site. Estimated sediment yields for 1987, when compared to premaneuver estimates, were larger for 1 drainage basin, smaller for 16 drainage basins, and unchanged for 4 drainage basins. Increased ground cover and the decreased areal extent of land use combined to decrease estimated sediment yields.

During November 1987 , sediment yields were estimated for seven drainage basins located off the Maneuver Site. Estimated sediment yields for November 1987, when compared to estimates for water years 1983 through 1985, decreased for six drainage basins and were unchanged for one.

Nine seasonal precipitation gages were installed in the Taylor Arroyo drainage basin during water year 1987. Daily and unit precipitation and streamflow data collected in the Taylor Arroyo drainage basin during water year 1987 were used to calibrate a watershed model, the Precipitation-Runoff Modeling System (PRMS).

The measured and simulated annual volume of runoff from the drainage basin compared well. The annual volume of measured runoff for water year 1987 was $0.10 \mathrm{in.}$ The simulated volume of runoff was 0.11 in. The comparison of the measured and simulated hydrographs indicates that the large storm of August 9, 1987, is modeled fairly well; the simulated daily mean streamflow of $76 \mathrm{ft}^{3} / \mathrm{s}$ compared reasonably to the measured streamflow of $82 \mathrm{ft}^{3} / \mathrm{s}$. The measured and simulated daily mean streamflows were similar during the smaller storms that occurred in October 1986 and May 1987. An exception to the overall good comparison occurred on July 2. On this date the measured daily mean streamflow was $22 \mathrm{ft}^{3} / \mathrm{s}$, and the daily mean streamflow simulated by the model was $0.0 \mathrm{ft}^{3} / \mathrm{s}$. Why the outflow from this storm is not simulated accurately is not known; antecedent soil moisture and the timing and spatial distribution of the precipitation probably are contributing factors.

Unit calibration of PRMS to the storm of August 9, 1987, in the Taylor Arroyo drainage basin was done. The comparison of the measured and simulated streamflow indicates that the volume in the simulated streamflow is larger by $0.05 \mathrm{in}$. The volume of the observed outflow was $0.06 \mathrm{in.}$, and simulated outflow was $0.11 \mathrm{in}$. The measured peak streamflow was $669 \mathrm{ft}^{3} / \mathrm{s}$ and occurred 
at 0900 . The predicted peak streamflow was $650 \mathrm{ft}^{3} / \mathrm{s}$, a difference of about 3 percent and also occurred at 0900 . Hypothetical effects of military maneuvers on the streamflow for this particular storm were simulated by using PRMS. Disturbance from military maneuvers was estimated for each hydrologic response unit in the Taylor Arroyo drainage basin. This hypothetical scenario increased the simulated peak streamflow about 1.2 percent, and there was no change in the timing of the streamflow.

\section{REFERENCES CITED}

Cain, Doug, 1987, Relations of specific conductance to streamflow and selected water-quality characteristics of the Arkansas River basin, Colorado: U.S. Geological Survey Water-Resources Investigations Report 87-4041, $93 \mathrm{p}$.

Camp, Dresser, and McKee, Inc., 1984, The effects of tracked vehicles traffic on undisturbed soils, Fort Carson Military Reservation: Denver, 44 p.

Chambers, J.M., Cleveland, W.S., Kliner, B., and Tukey, P.A., 1983, Graphical methods for data analysis: Boston, Duxbury Press, 395 p.

Colorado Climate Center, 1984, Colorado average precipitation map, 1951-1980: Fort Collins, scale 1:500,000, 1 sheet.

Colorado Department of Health, 1982, Classification and numeric standards, Arkansas River basin: Denver, Water Quality Control Commission, $59 \mathrm{p}$.

Crawford, C.G., Slack, J.R., and Hirsch, R.M., 1983, Nonparametric test trends in water-quality data using the statistical analysis system: U.S. Geological Survey Open-File Report 83-550, 102 p.

Dickinson, W.T., and Whiteley, H.Q., 1970, Watershed areas contributing to runoff, in Symposium on the Results of Research on Representative Experimental Basins, Wellington, New Zealand, 1970, Proceedings: Paris, International Association of Hydrologic Sciences Publication 96, p. $12-28$.

Hem, J.D., 1985, Study and interpretation of the chemical characteristics of natural water (3d ed.): U.S. Geological Survey Water-Supply Paper 2254, $263 \mathrm{p}$.

Hewlett, J.D., and Nutter, W.L., 1970, The varying source area of streamflow from upland basins, in Symposium on Interdisciplinary Aspects of Watershed Management, Bozeman, Mont., 1970, Proceedings: New York, American Society of Civil Engineers, p. 65-83.

Iman, R.I., and Conover, W.J., 1983, A modern approach to statistics: New York, John Wiley, $497 \mathrm{p}$.

Leavesley, G.H., Lichty, R.W., Troutman, B.M., and Saindon, L.G., 1983, Precipitation-runoff modeling system--User's manual: U.S. Geological Survey Water-Resources Investigations Report 83-4238, $207 \mathrm{p}$.

Livingston, R.K., and Minges, D.R., 1987, Techniques for estimating regional flood characteristics of small rural watersheds in the plains region of eastern Colorado: U.S. Geological Survey Water-Resources Investigations Report 87-4094, 72 p.

Martin, J.D., and Crawford, C.G., 1987, Statistical analysis of surface-waterquality data in and near the coal-mining region of southwestern Indiana, 1957-80: U.S. Geological Survey Water-Supply Paper 2291, 92 p.

McCain, J.F., and Jarrett, R.D., 1976, Manual for estimating flood characteristics of natural-flow streams in Colorado: Denver, Colorado Water Conservation Board Technical Manual no. 1, $68 \mathrm{p}$. 
Morel-Seytoux, H.J., and Khanji, J., 1974, Derivation of an equation of infiltration: Water Resources Research, v. 10, no. 4, p. 795-800.

National Climatic Data Center, 1972-87, Climatological Data--Colorado: U.S. Department of Commerce, National Oceanic and Atmospheric Administration, vol. 76, no. 10, to 93 no. 9 (published monthly), Ashville, North Carolina.

Pacific Southwest Inter-Agency Committee, 1968, Report on factors affecting sediment yield in the Pacific Southwest area: Water Management Subcommittee, Sedimentation Task Force, $10 \mathrm{p}$.

Rawls, W.J., and Brakensiek, D.L., 1983, Advances in infiltration: St. Joseph, Mich., American Society of Agricultural Engineering Publication 83-11, p. 102-112.

Rosenbrock, H.H., 1960, An automatic method of finding the greatest or least value of a function: Computer Journal, v. 3, no. 1, p. 175-184.

U.S. Soil Conservation Service, 1983, Soils manuscript for the Pinon Canyon Maneuver Site: Trinidad, Colo., unpublished report, $157 \mathrm{p}$.

von Guerard, Paul, and Abbott, P.0., and Nickless, R.C., 1987, Hydrology of the U.S. Army Pinon Canyon Maneuver Site, Las Animas County, Colorado: U.S. Geological Survey Water-Resources Investigation Report 87-4227, $117 \mathrm{p}$. 